I N T ER N ATIONAL MONETARY FUND

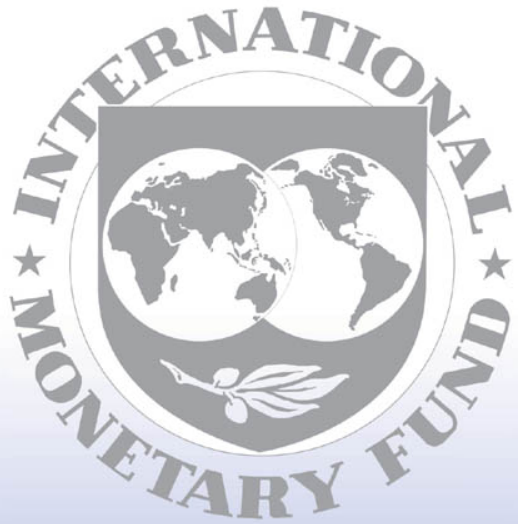

Staff

Country

Reports 


\section{Germany: Selected Issues}

This Selected Issues paper for Germany was prepared by a staff team of the International Monetary Fund as background documentation for the periodic consultation with the member country. It is based on the information available at the time it was completed on October 9, 2002. The views expressed in this document are those of the stafl team and do not necessarily reflect the views of the government of Germany or the Executive Board of the IMF.

The policy of publication of staff reports and other documents by the IMF allows for the deletion of market-sensitive information.

To assist the IMF in evaluating the publication policy, reader comments are invited and may be sent by e-mail to Publicationpolicy@imf.org.

Copies of this report are available to the public from

International Monetary Fund - Publication Services

700 19th Street, N.W. - Washington, D.C. 20431

Telephone: (202) 6237430 • Telefax: (202) 6237201

E-mail: publications@imf.org • Internet: http://www.imf.org

Price: $\$ 15.00$ a copy

\section{International Monetary Fund \\ Washington, D.C.}




\section{INTERNATIONAL MONETARY FUND}

\section{GERMANY}

\section{Selected Issues}

Prepared by Jörg Decressin, Laura Kodres and Christoph Klingen (all EU1)

Approved by the European I Department

October 9,2002

Contents

Overview. .5

I. Growth and Adjustment in Germany: Perspectives and Prospects.................................6

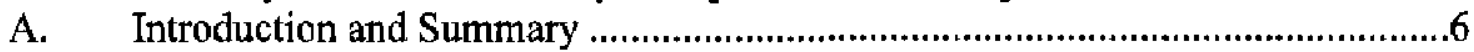

B. The Economic Performance ...........................................................................

C. Supply-Side Developments..................................................................10

The contribution of labor .............................................................................10

The contribution of capital ..................................................................14

The contribution of total factor productivity ..................................................15

D. A Decade of Economic Adjustments ................................................................17

The demand side: public sector adjustment and the interplay

with monetary conditions........................................................................18

The effects of changes in the sectoral composition of output...........................19

Integrating the new Länder ..........................................................................20

E. Economic Adjustment: The Road Ahead …...............................................23

Appendix I $\quad$ Identifying Labor Supply and Demand...................................................27

Appendix II Macroeconomic Model Simulations ................................................30

References.....................................................................................................

II. Is Germany Competitive? ..................................................................................65

A. Real Exchange Rate Trends and Profitability ..................................................66

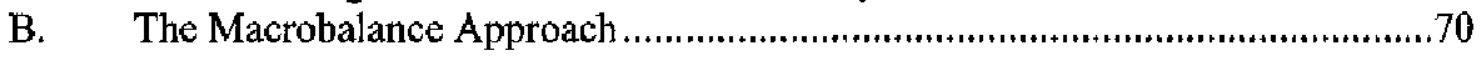

C. $\quad$ Export Market Shares …......................................................................72

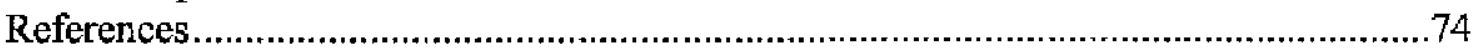

III. The Slowdown in Credit Growth.........................................................................75

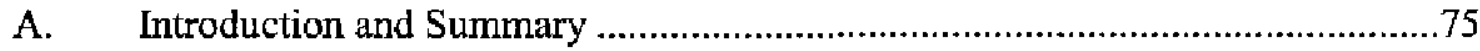

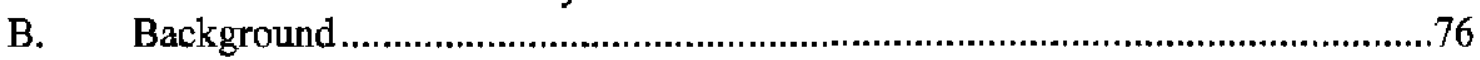




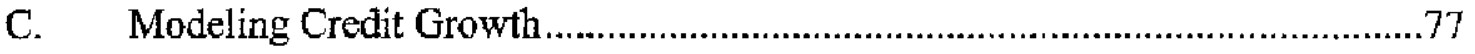

The structural model ..........................................................................................77

A less-structured model ...............................................................................81

Alternative definitions of credit and activity ..............................................82

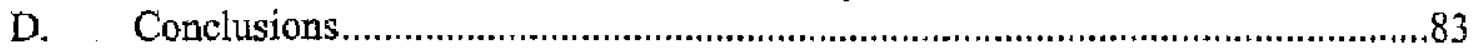

Appendix Data Sources and Definitions..........................................................84

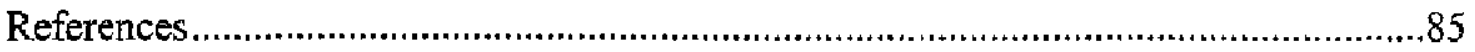

IV. The Fiscal Challenge of Aging: What Needs to Be Done …........................................86

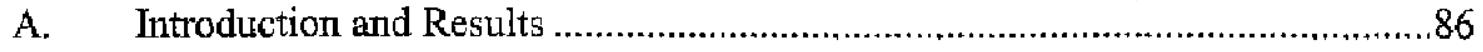

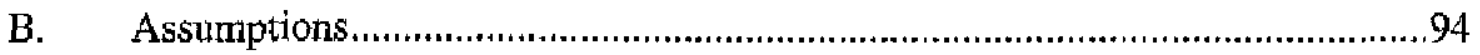

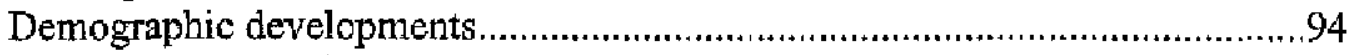

Macroeconomic environment ..................................................................96

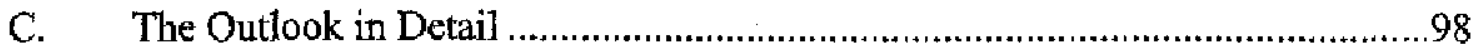

Public pensions ........................................................................................ 98

Civil service pensions ....................................................................................100

Health eare expenditure .....................................................................................101

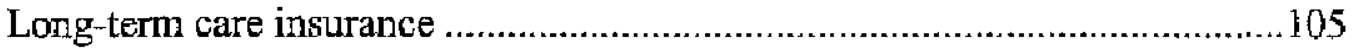

Appendix

Remaining aspects of public finances...............................................................106

Expenditure of Public Pension Fund (GRV), 2000-2050 ….........................107

Expenditure for Civil Service Pensions, 2000-2050 ..................................108

Health Care Expenditure, 2000-2050 …...................................................109

Long-term Care Expenditure, 2000-2050 ................................................109

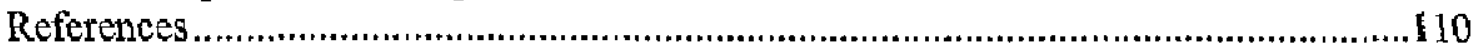

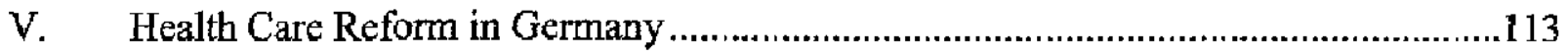

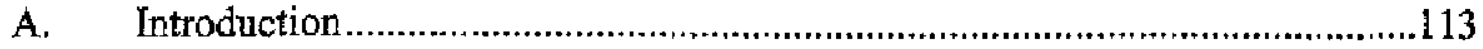

B. The German Health Care System ...........................................................115

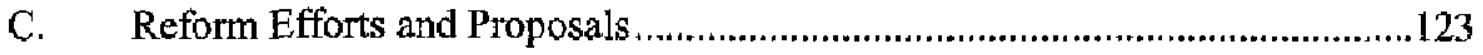

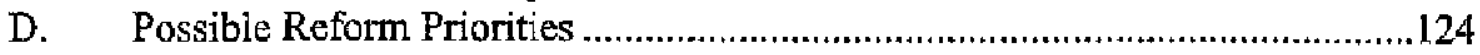

Patient co-payments .....................................................................................125

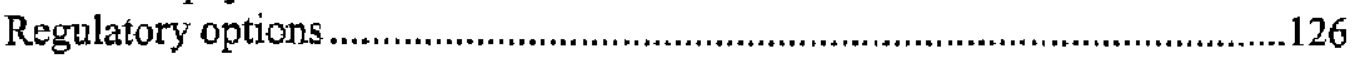

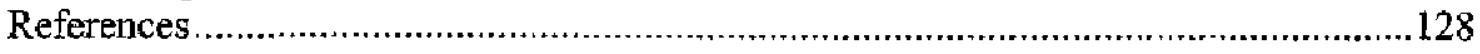

Text Box

I. Taxation and Labor Supply............................................................................13

Tables

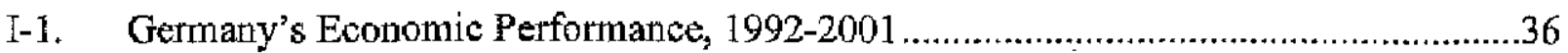

I-2. The Years Preceding German Unification, 1989-1991_..........................................37

I-3. Germany's Labor Market Performance, 1992-2001 .............................................38

I-4. Growth Accounting, 1992-2001 ..........................................................................39 


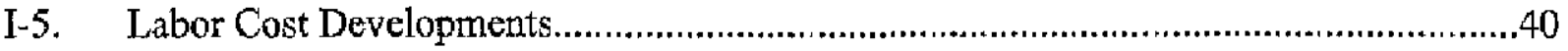

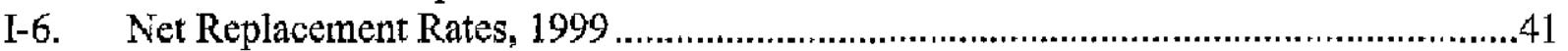

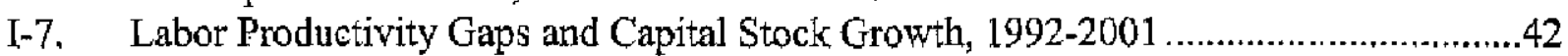

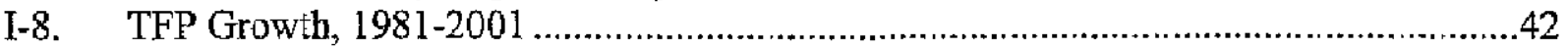

I-9a. $\quad$ Regulatory Reform in Product Markets, 1978-1998..........................................43

I-9b. Detailed Indicators of Product Market Regulation, 1998 .........................................43

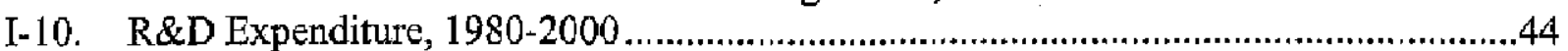

I-11. Employment Protection Legislation ...................................................................44

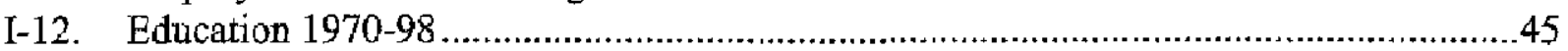

I-13. Ranking Educational Achievement Based on 2000 PISA Study..............................45

I-14. The Role of the Public Sector, 1992-2001 ….....................................................46

I-15. Explaining the Per Capita Real GDP Growth Differences, 1992-2001 .........................47

I-16. The Size of Industry, Energy and the Construction Sectors ........................................48

I-17. Value Added Excluding Construction, Industry, and Energy ....................................48

I-18. Job Growth in Manufacturing.........................................................................49

I-19. Turbulence: Standard Deviation of Sectoral Growth Rates...........................................49

I-20. Public Sector Balances...................................................................................50

I-21. ' Primary Structural Fiscal Balances, 1991-2001 ….................................................50

III-1. Structural and Non-Structural Equation Results ................................................ 80

IV-1. General Government Operations, 2001-50 …........................................................90

IV-2. Summary of Macroeconomic Developments, 2001-07 .............................................96

IV-3. Labor Force Participation Rates...........................................................................97

IV-4. Health Expenditure By Age Group ........................................................................102

V-1. Health Care Expenditure, 1970-2000 .......................................................................119

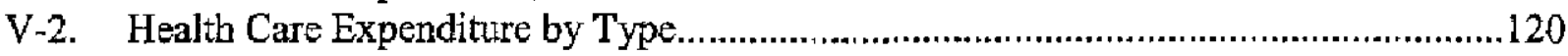

V-3. Health Care Expenditure by Type, 1970-2000 .................................................120

V-4. Evolution of Per Capita Expenditure of Public Health Insurance Funds,

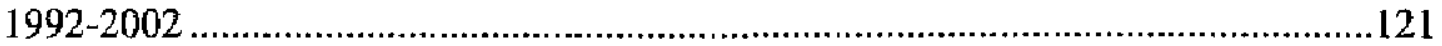

V-5. Indicators of Health Care Resources................................................................122

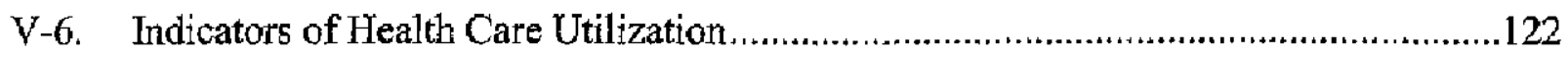

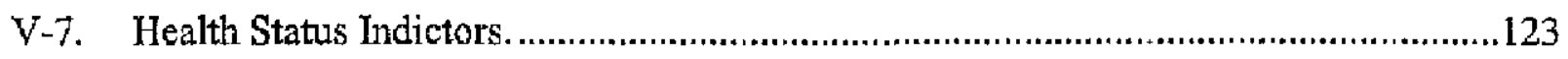

Figures

I-1. A Factor Decomposition of Business Sector Real GDP Growth, 1980-2001 ..............51

I-2. Labor Supply and Factor Proportions, 1980-2001 .............................................52

I-3. Unemployment and Gross Replacement Rates, 197.1-2001 ....................................53

I-4. Taxes and Contributions, 1980-2001 ...............................................................54

I-5. Labor Demand and Payroll Taxes, 1970-2001 _...................................................55

I-6. Fiscal Policy and Monetary Conditions, 1991-2001_............................................56

I-7. Government Revenue and Primary Expenditure, 1991-2001 .................................57

I-8. Value Added in Industry and Energy and the Real Exchange Rate, 1980-2001 ...........58

I-9. Economic Convergence Compared, 1991-2001 ….................................................59 
I-10. East-West Convergence, 1991-2001 ............................................................60

I-11. East-West Unemployment and Labor Costs, 1991-2001 „.........................................61

I-12. Real GDP Growth and Asset Prices.................................................................62

I-13a. Response to Innovation in US Real GDP Growth Rate, 1992:1-2001:4 ....................63

I-13b. Response to Innovation in Deviation of US Real GDP from US HP-Filtered

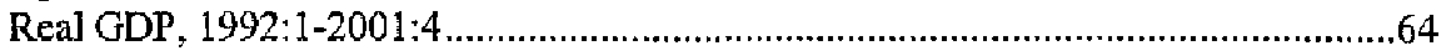

II-1. Real Effective Exchange Rates Against 19 Industrial Countries,

1960-2002

I-2. Nominal Real Effective Exchange Rate, 1988-2002 ….......................................67

II-3a. Nominal Effective Exchange Rate and Selected Bilateral Rates

Against Euro Area, 1988-2002 ……...........................................................68

II-3b. Real Effective Exchange Rate CPI-Based Against Euro Area, 1988-2002 ..................68

II-4a. Real Effective Exchange Rate Based on Unit Labor

Cost in Manufacturing, 1988-2002

Il-4b. Real Effective Exchange Rate Based on Unit Labor

Cost in Business Sector, 1988-2002

II-5. Index of Employment in Manufacturing........................................................69

II-6. Selected European Countries: Business Sector Profitability, 1/, 1988-2002................69

II-7. SI Norm and Underlying Current Account, 1984-2001.........................................72

II-8. $\quad$ Export Market Shares within Various Regions, 1980-2001 ........................................73

III-1. Growth of Private Domestic Credit to Non-Banks in

Germany and the Euro Area. .75

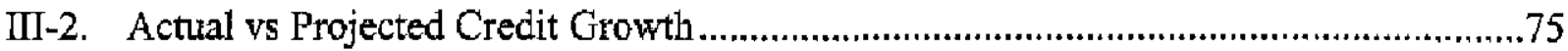

III-3. Net Interest Rate Margins for Selected Bank Types................................................76

III-4. Model Projections of Credit Growth.........................................................................81

III-5. Total Liabilities of Non-Financial Enterprises .......................................................82

IV-1. Development of Age-Related Public Expenditure, 2000-50 ….................................88

IV-2. Evolution of Fiscal Deficits and Public Debt, 2000-50 ...........................................91

IV-3. Evolution of Baseline and Required Social Security Contribution Rates, 2000-50 ......92

IV-4. Population Dependency Ratios, 1980-2050 ...................................................95

IV-5. Public Pension Fund Expenditure, 2000-2050_.......................................................99

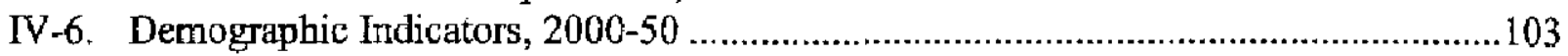

IV-7. Per Capita Health Expenditure by Age Group .......................................................104

V-1. Health Care Expenditure by Sponsoring Agency, 2000 ...........................................118

$\mathrm{V}-2$. Social Contribution Rates for Health Care and Pensions, 1970-2002 .........................118 


\section{Overview}

This selected issues paper focuses on two main themes; Germany's growth record and how future performance might be enhanced; and the longer-term strains on the public finances.

Chapter I reviews Germany's growth record in 1992-2001. During this period, per capita real GDP growth was both low and lagged behind that in other European cotntries. Some of the growth differential can be put down to Germany's unique cyclical position following the unification-related boom at the beginning of the 1990s. However, correcting for the cycle, growth was still significantly lower than in the United Kingdom and the Netherlands. A crucial difference was Germany's relative inability to create jobs, a failing that is linked to generous welfare systems, which tended to absorb displaced labor into long-term unemployment or early retirement, as well as to a rising burden of tax and social security contributions. The chapter stresses that the 1990 s were a testing time for labor markets as the policies to integrate the new Länder into Germany's economic system precipitated enormous shifts in the structure of output. While the growth record should in principle improve in the next decade, reducing the vulnerability of the economy to shocks and dealing with the legacy of high unemployment requires reforms to labor markets.

Chapters II and III complement this analysis. Chapter II reviews Germany's external competitiveness, which deteriorated substantially in the wake of unification. It concludes that, by the beginning of the current decade, competitiveness had been largely restored. At a multilateral level, this partly reflected general euro weakness. But more fundamentally, the manufacturing sector responded to earlier real exchange rate appreciation by downscaling and improving productivity. Within the euro area, Germany's competitiveness is more ambiguous, but export market share has begun to recover in recent years. Chapter III examines the recent slowdown in credit, which has gone beyond what might be expected on cyclical grounds. While identifying supply-side factors is problematic, the unexplained credit weakness is consistent with the need for restructuring in the banking system and ongoing efforts to improve credit-risk management.

Chapters IV and V adcress fiscal sustainability issues. Chapter $I V$ analyzes the impact of population aging on the fiscal accounts. Pulling together all age-sensitive expenditures in a consistent macroeconomic framework, it highlights the need for additional reforms to entitlements. Various scenarios show that the huge long-term costs of aging cannot be absorbed in a fully sustainable manner under current plans to run modest budget surpluses in the medjum term. Indeed, given the limited scope to shrink non-entitlement spending, it is hard to see how such surpluses can be generated or sustained without entitlement reforms. Chapter $V$ puts an additional spotlight on the health care system. Public spending on health as a share of GDP is the highest in the world and future health care costs will likely come under pressure from medical advancements as well as from demographics. The chapter notes that health care reform is a contentious issue in all countries and there are few ready-made answers. However, a strong case for increasing copayments can be made as this should at least begin to correct the lack of incentives to curb demand for and supply of health services. 


\section{Growth and AdJustment in Germany: Perspectives and Prospects ${ }^{1}$}

\section{A. Introduction and Summary}

1. This chapter advances various hypotheses to help understand Germany's low real GDP growth during 1992-2001 with a view to informing the discussion on policies to improve the country's economic performance. Per capita real GDP growth during this period was a modest $1 \frac{1 / 3}{3}$ percent a year. Much of the retrospective analysis relies on crosscountry comparisons with France, Italy, the Netherlands, and the United Kingdom (UK), against which Germany's growth rate lagged by $1 / 3-1$ percentage point. These countries have similar per capita income levels to Germany and offer enough variance in terms of growth performances and policies to form some tentative conclusions. ${ }^{2}$ Developments in eastern Germany are also compared to those in the Czech Republic, Hungary, Poland, and Portugal to assess the structural transformation that bas taken place since unification.

\section{At the aggregate level, the main reasons for Germany's poor economic performance relative to the comparator countries are:}

- Cyclical developments. Following a 15 percent expansion of the west German economy during 1989-91, Germany entered the 1990s with unemployment below its natural rate by a larger margin than in the other countries. The unwinding of the economic tensions from the unification-related boom slowed real GDP growth in the 1990s. Today, Germany's econorny is operating with more slack than the other countries reviewed.

- Smaller efficiency gains. Even after adjusting for the business cycle, a per capita real GDP growth gap of about $1 / 2$ percentage point per annum remains relative to the Netherlands and the UK. Germany was less successful than these countries in pushing out its production possibility frontier through a better use of labor resources, In both the Netherlands and the UK, unemployment rates declined for a given level of labor costs, indicating a structural increase in labor supply. This increase was supported by reforms to the welfare system. By contrast, in Germany generous benefits for the

\footnotetext{
${ }^{1}$ Prepared by Jörg Decressin.

${ }^{2}$ Cross-country comparisons raise important measurement issues, which lie beyond the scope of this paper. For example, countries have made uneven progress in implementing the 1993 System of National Accounts (SNA), notably with respect to producing revised historical data. Other issues arise with respect to prices, particularly the use of chain and fixedweighted indices and the treatment of information technology products. This paper mostly relies on data from the OECD's Economic Outlook or Analytical databases, which have been adjusted to facilitate international comparisons. See Scarpetta and others (2000), Annex 2, for further information.
} 
jobless and tax and contributions increases to fund the extension of the west's weifare system to the east hindered a structural increase in labor supply.

3. Behind the aggregate developments were much larger sectoral and structural changes than in the other countries reviewed:

- First, there were major shifts in fiscal policies. A sizable expansion of the fiscal deficit took place during the early years of unification to fund the extension of infrastructure and the welfare system to the new Länder. Subsequently, Germanytogether with Italy-undertook the largest fiscal effort among the comparator countries to put its public finances on a sounder footing. In that process, government employment was cut by about 0.8 million and revenues were increased significantly. Consolidation likely dampened demand. But tax and contributions increases may also have had a significant impact on aggregate supply.

- Second, a large appreciation of the real exchange rate hastened the downsizing of the manufacturing sector. Germany started the 1990 s much more exposed to industry and thus less resilient to external shocks, Over the past decade, the share of industry in value added shrunk considerably - a process that was accelerated by the appreciation of the deutsche mark (DM) around unification - to reach a size that is broadly comparable to that in the other countries reviewed.

- Third, the construction sector went from boom to bust. The construction sector was initially a major winner from unification. But the rebuilding boom eventually collapsed and the construction sector has been in a deep recession since 1997.

- Fourth, the economic landscape of new Länder was transformed. While unificationrelated policy changes and sectoral adjustments held back growth in the west, the growth performance in the east was fairly impressive: in terms of per capita GDP, the new Länder now resemble Portugal. However, overly rapid convergence of wages toward western levels has left a legacy of high unemployment in the east.

4. Weathering these adjustments more successfully would have required more resilient economic institutions - and, in particular, better functioning labor markets. Rather than fostering the rapid reintegration of job losers into the labor market, the welfare system essentially absorbed them into long-term unemployment or de facto early retirement. In addition, employment protection legislation and regulated product markets inhibited the reallocation of jobs to expanding sectors.

5. The conclusion that the labor market must take part of the blame for Germany's poor growth performance is well documented in other studies. For example, EU (2002a) attributes about one third of the difference in Germany's real GDP growth differential with its EU partners between 1995-2001 to structural factors. It specifically singles out the labor market--insufficient wage differentiation across skills and regions, poverty traps, and a lack of general flexibility and mobility. Taking a longer view, Scarpetta and others (2000) find 
that failure to increase labor utilization in the euro area, and particularly in Germany, accounts for why per capita GDP in Europe has been falling further behind that of the United States since 1985.

6. For the next decade, unification strains will be having a signiffeantly lower impact on the economy, but an improved growth performance cannot be assured without reforms. On present trends, per capita potential real GDP growth could in principle reach about $1 \frac{3 / 4}{4}$ percent a year. Achieving or exceeding this would require:

- Putting more people to work, particularly in the new Länder. Although Germany's employment-to-population ratio is not low by EU standards, ample scope remains for raising employment. In the first instance, this might be achieved by raising the employment rate of 55-64 year olds, which stands at under 40 percent, and reducing the high unemployment rate in the east. In addition, the incentives of the low skilled-which, according to EU (2000a), account for over one third of the unemployed in the western Lander-to accept full-time jobs need to be strengthened. This could be accomplished by: (i) for older workers, reducing the length of unemployment benefit duration from 32 months to the standard length of 12 months, while subsidizing their on-the-job training with social security exemptions; (ii) eliminating poverty traps, by linking part of the receipt of benefits for the jobless to mandatory training or the performance of publicly useful work; and (iii) continuing with moderate wage settlements and creating more room for wage differentiation.

- Raising productivity. Gernany's total factor productivity (TFP) growth does not compare unfavorably with the other countries reviewed. But European economies missed out on the surge of TFP growth seen in the United States in the 1990s. The reasons for the acceleration in the United States and its sustainability are not well understood. Nonetheless, ample scope remains for Germany to improve the quality of its education and deregulate its product markets, two drivers of TFP growth. In addition, the new Länder experienced a marked slowdown in TFP growth during the second half of the 1990s. More infrastructure and transfer of business skills to the east would help to speed closure of the remaining productivity gap with the west. ${ }^{3}$

7. The chapter is organized as follows. Section B provides a descriptive analysis of Germany's growth performance. Section C investigates supply-side developments, focusing on the contributions of labor, capital, and TFP to real GDP growth. Section D reviews fiscal policy, sectoral changes in output, and the integration of eastem Gemany in the 1990s. Section E concludes.

${ }^{3}$ See also Burda and Hunt (2001). 


\section{B. The Economic Performance}

8. For the period 1992-2001, the economic cycle works against Germany in growth comparisons with other $\mathbf{E U}$ countries (Table I-1). In particular, this period does not include the unification-boom years. Unification caused a surge in investment and consumption and boosted real GDP in western Germany by some 15 percent during 1989-91 (Table I-2). This surge meant that Germany's 10-year average growth rate remained above that in all the other countries reviewed, except for the Netherlands, through 1999. ${ }^{4}$ In 2001, the year when the 10-year average no longer

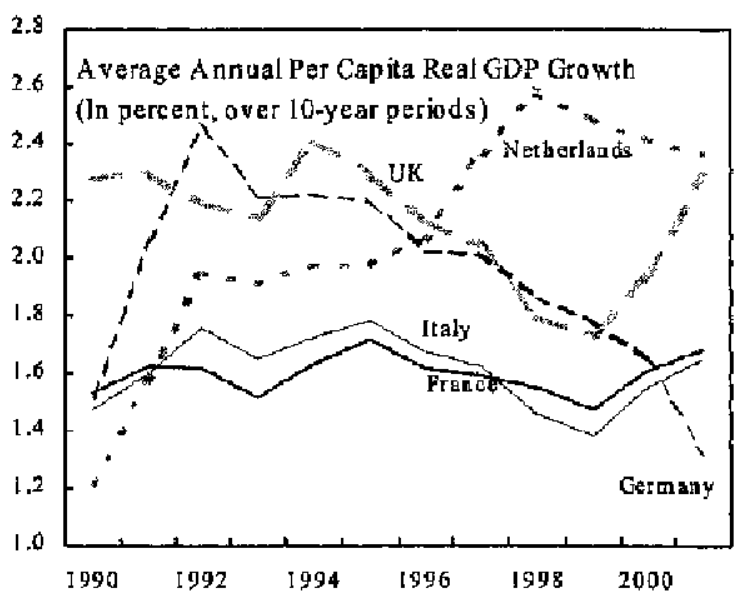
includes any of the unification-boom years, Germany falls to the bottom of the league. ${ }^{5}$

9. Nonetheless, the economic cycle explains only part of the growth gap relative to the high growth countries. By focusing on potential real GDP growth in per capita terms, the effects of the cycle and of population growth are removed. On that measure, Germany still ranks low, although together with France and Italy. The growth gaps relative to the other countries vary somewhat depending on whether OECD or IMF staff estimates of potential output growth are used, but broadly suggest that Germany's potential output growth lagged that of the Netherlands and the UK by about $1 / 2$ percentage point.

10. Sharp reductions in the estimated natural rate of unemployment underlie the estimates of higher potential output growth for the Netherlands and the UK in the 1990s. Relative to Germany, the natural rate in these countries is estimated to have declined by roughly $1 / 4$ percentage point per annum since 1991 (Table III-3). As (hours adjusted) annual labor productivity growth has typically fluctuated between $1 \frac{1}{2}-2$ percent for all three countries, this decline basically accounts for the full $1 / 2$ percentage point growth differential in per capita potential output.

\footnotetext{
${ }^{4}$ Based on a backward-looking, geometric moving average of growth rates. To splice data for western and united Germany, GDP for the years preceding 1991 were adjusted upwards by 8.7 percent, the estimated weight of east Germany's real GDP in the German total of 1991.

${ }^{5}$ The 1993 recession has a large effect on Germany's average growth rate over 1992-2001: excluding that year, raises the average by almost $1 / 3$ percentage point. However, the effect of that recession on the other countries reviewed is very similar, with the exception of the UK, for which it does not affect average growth.
} 
11. More broadly, Germany's labor market performance slipped relative to the other countries in the past decade. At the beginning of the $1990 \mathrm{~s}$, Germany's employment ratio (actual or hours adjusted) compared favorably with the other countries, coming second only to that in the UK (see Table I-3). ${ }^{6}$ But a relatively poor job-creation record allowed the other countries to make up ground-or, in the case of the UK and Netherlands, to surge ahead. And relative to France and Italy, Germany still has a lower structural unemployment rate, but the differential has narrowed. Structural unemployment is much lower in the UK and Netherlands.

\section{Supply-Side Developments}

12. A factor decomposition of business sector real GDP growth over 1992-2001 reveals that Germany lagged the Netherlands and the UK significantly with respect to the contribution from labor; it also lagged France over 1997-2001 (Table I-4). ${ }^{7}$ The conclusion is the same if cyclical differences between the countries are smoothed out with 10-year backward moving averages (Figure I-1). Structural labor supply was held back in Germany by income and payroll tax hikes as well as by generous welfare benefits that fostered long-term unemployment and early retirement in response to economic shocks. Germany's TFP performance was relatively strong. But the contribution of capital to growth was surprisingly low considering that unification effectively increased the supply of labor.

\section{The contribution of labor}

13. The lower contribution of labor to output growth accounts fully for the per capita potential output growth gap with the Netherlands and the UK. Over the 1990s, the labor contribution to output growth was some $3 / 4$ percentage point lower per annum in Germany than in these countries. Adjusting for differences in population growth cuts that gap to about $1 / 2$ percentage point, or to the size of the difference between per capita potential output growth rates.

\section{Employment growth was slowed by higher labor cost growth in Germany} compared to the other countries reviewed, particularly during the first half of the decade (Table 1-5). The appropriate measure for labor costs is real effective compensation, defined as real wage compensation deflated by the ratio of TFP and the labor share. ${ }^{8}$ Over the

\footnotetext{
${ }^{6}$ Obtaining good data on hours worked per employee is difficult and thus these results need to be interpreted cautiously.

${ }^{7}$ The data in the OECD databases that permit a factor decomposition only cover business sector real GDP growth, not total real GDP growth, because of the difficulties in measuring inputs and outputs of the government sector.

${ }^{8}$ This assumes a balanced growth path with labor-augmenting technological progress. This assumption, in turn, ensures the existence of a well-specified, steady-state growth path, with an unchanged capital-output ratio. See, for example, Romer (1996).
} 
$1990 \mathrm{~s}$, real effective compensation fell in all the countries reviewed but least of all in Germany and the UK. In addition, as factor proportions adjust slowly to changes in factor costs, Germany's much larger increase in labor costs during the first half of the decade would have had major relevance for its recent labor market performance. However, it is important to separate out the extent to which the rapid labor cost growth in the early 1990 s may have reflected an economy that was operating beyond its "normal" production possibility frontier-and hence a tight labor market-as opposed to underlying factors.

15. Adjusting for temporary distortions in labor costs due to the economic cycle and fluctuations in productivity reveals that structural labor supply has increased in all the countries reviewed over the last 30 years, except for Germany (Figure I-2). A firmer understanding of labor market developments requires identifying structural changes in labor supply: that is changes in labor costs (unemployment) for a given level of unemployment (labor costs). Appendix I explains how labor costs and unemployment can be related in a typical labor supply schedule. ${ }^{9}$ Smoothing shifts of such a supply schedule with a 5-year backward moving average to remove temporary distortions to labor costs uncovers a structural decrease in German labor supply in the first haif of the 1990s, unlike in any of the other countries. However, a turnaround is evident around 1996. The equivalent interpretation is that Germany established structural moderation of wages much later than in the other countries.

16. The generosity, duration and administration of benefits for the jobless probably had a significant impact on labor supply developments. The benefit system fostered long-term unemployment and early retirement in response to labor market shocks, rather than downward adjustments in wages. Time series evidence suggests that, unlike the Netberlands and the UK, Germany did little to lower the gross replacement rates for the unemployed (Figure I-3). ${ }^{10}$ Even more important was the "duration dimension" of benefits in Germany, which does not show up in the data on replacement rates (Figures I-3 and I-4 and Table I-6). A more detailed analysis of employment ratios across age categories reveals that employment gaps relative to the UKthe country with the highest employment rate - are concentrated on the young and older

\footnotetext{
${ }^{9}$ See also MF, 2001.

${ }^{10}$ The only significant change in replacement rates in Germany was a modest 1-3 percentage point lowering in 1994.
}

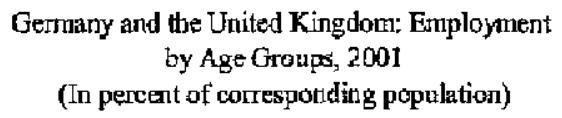

\begin{tabular}{lcccc}
\hline & Germany & U.K. & \multicolumn{2}{c}{ Missing jobs 1i } \\
\cline { 4 - 5 } Age & & & \multicolumn{2}{c}{ (In millions) (ln percent) } \\
\hline $15-64$ & 65.7 & 71.6 & 2.6 & 100 \\
$15-24$ & 46.5 & 55.6 & 0.8 & 31 \\
$25-49$ & 80.3 & 81.3 & 0.3 & 12 \\
$50-54$ & 74.5 & 77.3 & 0.1 & 6 \\
$55-59$ & 57.7 & 64.7 & 0.4 & 13 \\
$60-54$ & 20.8 & 37.6 & 1.0 & 3.8 \\
\hline
\end{tabular}

Source: Eurostst. 1/ Additional jobs if Germany had the same employment ratios for each age group as the U.K. 
workers. ${ }^{11}$ For those older than 53 years, benefit duration in Germany was raised from the standard 12 months to a maximum of 32 months during 1985-87 to facilitate early retirement. When the benefit period expires, unemployed persons qualify for unemployment assistance-with standard replacement ratios of 56-58 percent, as opposed to 63-68 percent under unemployment benefits- - -right up to the statutory retirement age of 65 years. ${ }^{12}$ Furthermore, for older workers in the new Länder who lost their jobs during 1990-93 a special program (Altersübergangsgeld) provides unemployment benefits until they qualify for an old-age pension.

17. While Germany made benefits for the jobless more generous in some crucial respects, the Netherlands and the UK did the opposite. The Netherlands reduced benefits during the decade up to 1995 and the UK did so mostly in the 1980s. Reductions in unemployment, disability, and sick leave benefits in the Netherlands are well documented; in addition, eligibility criteria for the various programs were tightened considerably. ${ }^{13}$ Similarly, benefits were lowered and eligibility criteria were tightened in the UK, the latter through various measures, including compulsory counseling in 1986; the disqualification from unemployment assistance of the 16-17 year olds in 1988; and the "Actively Seeking Work Rule" in 1989 (Nickell and Quintini, 2002). These examples illustrate that the administration of benefits, as well as their level and duration are crucial for labor supply. ${ }^{14}$

18. An increase in structural labor supply was also hampered by increases in taxation and employee-paid social security contributions (Figure I-4). As gross replacement rates remained essentially unchanged, rising taxes and contributions acted to slow labor supply and boost wages. In comparison with the Netherlands and the UK, the

${ }^{11}$ For the young, the lower employment ratio in Germany is related to the education system. Youth unemployment is very low: for 15-24 year olds it stood at 7.8 percent in 2001, compared with 10.3 percent in the UK.

${ }^{12}$ For the jobless who did not qualify for unemployment benefits (mostly those without sufficient work experience and thus not older workers), eligibility for unemployment assistance was tightened in 1994. Since then, they receive assistance only for one year.

${ }^{13}$ See Watson and others (1999). Some of this progress has been undone subsequently (IMF, 2002).

${ }^{14}$ Other countries that recorded noticeable labor markets improvements in the $1990 \mathrm{~s}$ implemented similar reforms. For example, Denmark, which provides benefits that are also generous and long in duration, reformed the system of job-search, allying it with sanctions if individuals do not fulfill their responsibility to look for and accept work (Nickell and Quintini, 2002). In Germany, sanctions exist if individuals reject acceptable jobs. The burden of proof that a rejected job was "acceptable" lies with the labor office. However, partly as a result of interpretations by the social courts, sanctions are applied very rarely. 
average rate for total payments less cash benefits rose by 11-15 percentage points for a single filer; for a married filer with one child, the rate rose by $2-6$ percentage points. Some estimates suggest that a 10 percentage point decrease in the tax wedge-an amount lying roughly in the middle of the range of changes observed for the Netherlands and the UK relative to Germany-would lead to a 25 percent reduction of the unemployment rate (see Box).

\section{Box: Taxation and Labor Supply}

The extent to which labor taxes affect the relation between post-tax pay and reservation wages both in the short and long run is fundamentally an empirical issue. Layard and Nickell (1999) in a review of the literature argue that "[t]here is some evidence that overall labor tax rates have a short-run, and possibly long-run, impact on unemployment rates." They put the reduction in unemployment that can be obtained with a 5 percentage point reduction in the tax wedge at 13 percent (e.g., from 8 percent to 7 percent of the labor force).

Rising labor taxation can pose more problems than high labor taxation. Assuming that capital is internationally mobile while labor is not, the incidence of labor taxes ultimately falls fully on labor. High labor tax countries thus need not have higher unemployment rates. However, following payroll and other tax hikes, unemployment may well rise until unions agree to lower wage floors or cease to seek offsetting wage increases.

To understand the role of labor taxation, recall that the relation between post-tax pay and the reservation wage matters for labor supply; the anatysis here has focused on pre-tax pay. Assume, for simplicity, that reservation wages are based on alternative eamings, which are also taxed, and that taxation is proportional. Standard models suggest that taxation does not matter then: the real wage drops in line with the reservation wage. However, what if individuals' utility depends on both the level of income and its change? There is supportive evidence for such behavior from work in the area of adaptation theory. Standard models would then suggest real wage resistance in the face of tax increases. Similarly, wage floors can prevent an adjustment in market wages in response to tax hikes; and progressive taxation can narrow differentials between market and reservation wages. Lastly, the reservation wage may be a function of untaxed nonmarket activities, such as tending to children or the elderly.

\section{The more recent improvement in structural labor supply partly reflects}

moderate wage settlements. While wage moderation will secure existing jobs and boost employment prospects for labor market entrants, its sustainability is questionable absent welfare reform. In the interim, wage moderation might have a depressing effect on aggregate demand until factor proportions react. Some studies of investment find a lag of two to three years between the beginning and completion of an investment project. ${ }^{15}$ For projects that entail fundamental changes in factor proportions, the lags are likely to be longer. For

${ }^{15}$ See Jorgenson (1971) for a review of some studies. 
example, Blanchard (1998) assumes a mean lag of four years in the adjustment of factor proportions. Notice that in all the other countries reviewed, labor market conditions improved only many years after wage moderation had set in: in the Netherlands, toward the end of the 1990s; in the UK in the mid-1990s; and in France and Italy only toward the end of the 1990s. In the Netherlands, wage moderation started with the Wasenaar agreement in November 1982. In the UK, more moderate wage settlements owed to the decline in union power, stemming partly from changes in trade union laws (Nickell and Quintini, 2002).

\section{Germany's comparatively subdued labor market performance does not appear} to be related to structural declines in the demand for labor that may have been prompted by changes in the production structure. A satisfactory characterization of labor demand with good empirical backing is much harder to obtain than an aggregate labor supply schedule (Appendix I). With a simple Cobb-Douglas production function, a technologydriven decline in labor demand can be thought of as a drop in the labor share in outputalthough a drop in labor demand because of less union bargaining power is observationally equivalent. In this regard, Germany did not fare significantly worse than any of the other countries, except for the UK (Figure I-5) ${ }^{16}$ Allowing for costs in the adjustment of factor proportions does not materially change the picture. The relatively favorable structural labor demand in Germany might reflect more cooperative labor relations during the 1970 s and part of the 1980s than in the other countries reviewed.

21. A better performance of labor demand in Germany was, however, obstructed by payroll tax hikes (Figure I-5). Unless payroll tax hikes are compensated with more moderate wages, they boost unemployment. In the Netherlands and the UK, the effective payroll tax rate generally fell during the $1980 \mathrm{~s}$ and $1990 \mathrm{~s}$, thereby boosting labor demand. By contrast, in Germany the rate generally increased, in particular over 1992-1998. Taking a longer view, none of the countries have managed to reduce the effective payroll tax rate, except for the UK. In the Netherlands, considerable progress was made during 1985-95, but this appears to have been undone recently. However, as the payroll tax rates were raised, they were compensated for with more moderate wage growth.

\section{The contribution of capital}

22. The contribution of capital to output in Germany in the 1990s was lower than in the other countries reviewed. Since the quality of German capital stock data was affected by unification, the differences between the countries-which are not large - should not be overemphasized. Nonetheless, from the perspective of neoclassical growth theory and supporting empirical evidence Germany's performance was disappointing.

\footnotetext{
${ }^{16}$ Serres and others (2002) adjust the labor share for changes in the sectoral composition of output. Such an adjustment does not change the relative developments in labor shares shown in Figure I- 5 but reduces the decline in all countries. For Germany, such an adjustment reveals that the labor share has actually risen slightly during 1970-2000.
} 
23. In fact, with its productivity level at the beginning of the 1990s below that in the other countries, the forces of income convergence should have boosted Germany's relative productivity growth. Because of a higher return to capital, and thus a higher rate of per capita capital accumulation, Barro and Sala-i-Martin (1995) show that the catch-up of output per capita of poorer with richer entities (" $\beta$-convergence") across European regions proceeded at a rate of 1 percent per annum over $1980-90 .{ }^{17}$ A 1 percent rate of $\beta$-convergence implies that a country with a 10 percent labor productivity gap relative to the average should post 0.1 percentage point faster per capita real GDP growth per year, other variables remaining unchanged. For capital accumulation, this translates into a higher per capita growth rate of about 0.3 percentage points, as the share of capital in output was roughly one third. At the beginning of the $1990 \mathrm{~s}$, because of the low level of productivity in the new Lander, productivity in Germany was significantly lower than in the other countries reviewed, except for the UK (Table I-7). Simple calculations suggest that this should have meant that capital accumulation exceeded the rates in France, Italy, and the Netherlands by roughly $1 / 3-3 / 4$ percentage point per annum. Instead, Germany's actual performance fell short of that in those countries.

24. The key element behind the subdued rate of capital accumulation in Germany is likely to have been the behavior of wages. While productivity dropped considerably with unification, average wages declined much less: in 1991, unit labor costs were some 50 percent higher in the new Länder than in the old Lander. Wage growth in the new Länder continued to be fueled in the following years by wage catch-up to the west. With wages not behaving as assumed in the neoclassical growth framework, investment failed to stage a stronger performance than in the other countries. ${ }^{18}$

\section{The contribution of total factor productivity}

25. Germany's TFP growth in the 1990s was not significantly different from that in the other countries reviewed. In the short run, TFP is highly cyclical, mainly because it picks up changes in capacity utilization; including or excluding a few years in a growth comparison can make a large difference. A 10-year backward-looking geometric moving average of TFP growth reveals that Germany's performance has generally been strong. The only significant lag relative to another country, namely the UK, emerges in 2001, when none of the unification-related boom years are included (see Figure I-1). ${ }^{19}$ Removing cyclical

\footnotetext{
${ }^{17}$ Among the US states, per capita output converged at an annual rate of roughly 2 percent over the past century, according to Barro and Sala-î-Martin (1995).

${ }^{18}$ See also Bundesbank (2001) for similar conclusions on the relation between the labor market and capital accumulation.
}

${ }^{19}$ The 10-year average takes West German TFP growth rates until 1991. Data for 1991 are estimated from Germany's national statistics when West German real GDP is estimated to have grown by about 5 percent, employment by 2.6 percent, and the capital stock by 
effects using the Hodrick-Prescott (HP) filter series also suggests that Germany's TFP growth has been comparatively strong (Table I-8).

26. That said, TFP growth slowed in all the countries reviewed in the 1990s, in contrast to the experience of the US. The reasons for the TFP acceleration in the US are not well understood, nor is it clear how sustainable it is. It is partly related to information technology developments in the US but "how close [the] connection is and how exactly it works is not certain" (Baily, 2002). According to detailed case studies by McKinsey Global Institute (2001), the key factor behind the productivity acceleration in the US was competitive pressure that stimulated innovation. Also, a variety of sources contributed to boosting productivity, not just the information technology industry. Studies for EU countries have generally not been able to detect a similar contribution of information technology to growth as in the US. However, they have generally reached optimistic conclusions for the future, including for Germany (MF, 2000).

\section{If competition boosts innovation, then it could be a driving element af TFP}

growth. The literature case is ambiguous. On the one hand, more competition reduces firms' funding for research and development (R\&D) and their ability to appropriate profits from. innovation. On the other hand, neck-and-neck competition induces innovation by incumbents, particularly if the survival of firm and management are at stake. Using R\&D expenditure as a proxy for innovation, Bassanini and Ernst (2002) find a positive relation between less regulated product markets and innovation across OECD countries. Of direct relevance for the relation between TFP growth and competition are the results of Nickell (1996), who substantiates a positive link in a panel of 670 UK companies.

\section{Germany compares favorably to most of the other countries reviewed with} respect to indicators of product market regulation and spending on $R \& D$. For various reasons, competition may affect innovation in ways that are not captured by R\&D spending and thus the two sets of data should be considered complementary in assessing the TFP friendliness of the regulatory and institutional environment. According to Nicoletti and others $(2000,2001)$, Germany is ahead of the other countries reviewed-except for the UK-in both the current state and progress in improving product market regulation (Table I-9). Key remaining weaknesses are barriers to entry and excessive administrative regulation. Germany also spends a higher share of GDP on R\&D than all the other countries reviewed and only marginally less than the US (Table I-10).

29. The link between labor market regulation, in which Germany fares no worse than most of the other countries, and innovation/TFP is unclear. The link depends on the

3.4 percent. Based on the relation between total employment growth and business sector, hours-adjusted employment growth in 1990, this yields a business sector, hours-adjusted employment growth rate of 1.61 percent. With a labor share in income of roughly 0.65 , this yields TFP growth of 3.1 percent for 1991, up from 2.9 percent in 1990 . 
interplay of policies and institutions. Strong employment protection legislation (EPL) may induce "inside" workers to appropriate some of the benefits of innovation by renegotiating wages. Thus it may have a depressing effect on innovation and TFP growth. However, if labor relations are of a cooperative nature, the appropriation of innovation rents under strong EPL is less of an issue. Also, firms would then adjust production in response to innovation by retraining and redeploying workers rather than hiring and firing. Germany's employment protection legislation is rather restrictive if compared with the UK (Table I-11), but not relative to the other countries reviewed. However, Germany is also considered a country with cooperative labor relations: on that basis, Calmfors and Driffell (1988) rank Germany ahead of the UK in terms of delivering low wage growth and unemployment.

30. Declining relative education standards could have dampened TFP growth. While the effect of education should, in principle, be captured by a quality-adjusted labor input in the growth decomposition, adequate data to do so are not available. Based on educational attainment and assumptions about how many years of education a particular level of achievement represents, Germany leads the other countries reviewed in terms of levels of education (Table I-12). However, the change in educational achievement during the $1990 \mathrm{~s}$ was the lowest. Moreover, the data are not adjusted for differences in education quality, for which the OECD's PISA study (2002) revealed important weaknesses in Germany (Table I-13).

31. In sum, Germany's TFP growth and its driving forces do not compare unfavorably with the other countries reviewed, but there is ample scope to improve the quality of education and foster product market competition though streamlining administrattve regulations and removing barriers to entry. With fierce product market competition believed to be the driving force behind the acceleration in US TFP growth over the $1990 \mathrm{~s}$, deregulation and a vigilant anti-trust policy could play an important role in boosting German output growth in the future.

\section{A Decade of Economic Adjustments}

32. Changes in aggregate demand and the real exchange rate played a key role in unwinding unification-related tensions and set off adjustments in the structure of output and employment. First, following an expansion in the fiscal stance at the beginning of the 1990s, a major adjustment effort was undertaken to fund the integration of the new Länder without an undue expansion in government debt. Second, the fiscal expansion and unification-related construction boom raised the demand for nontradables, causing a sharp appreciation of the deutsche mark that accelerated the decline of Germany's relatively large industrial sector. This section reviews the impact of these developments on Germany's growth performance and takes stock of the progress in the economic integration of the new Länder. 
The demand side: public sector adjustment and the interplay with monetary conditions

\section{The two countries with the lowest real GDP growth in 1992-2001-Italy and} Germany-also made the greatest efforts to adjust their public finances (Figure I-6). Germany's adjustment was primarily achieved by raising revenue (Figure I-7), although the composition of spending changed as well. The size, composition, and length of the adjustment effort likely affected growth, with the revenue hikes limiting the potential nonKeynesian effects of fiscal adjustment. The consolidation effort followed a large loosening of policies in 1990 to fund unification. ${ }^{20}$ This loosening may have had an expansionary effect even in the subsequent years. Nevertheless, this is not considered in the following exercise, which explores the extent to which the policies and conditions prevailing during 1992-2001 can explain Germany's economic growth performance during those years.

\section{The direct contribution of the public sector to real GDP explains only some of} the growth gap with France and virtually none of the gap with the other countries. Using business sector data, which exclude the public sector, the growth gaps relative to Italy, the Netherlands, and the UK are little changed from the overall GDP gaps (Table I-14). Only the gap relative to France is virtually eliminated. Nonetheless, Germany reduced the government payroll throughout the $1990 \mathrm{~s}$ by some 0.8 million, an achievement comparable to that of the UK. This can be seen as a structural decline in labor demand in Germany. Avoiding a fall-out on unemployment would have required a more resilient labor market, notably a less generous welfare system.

35. Similarly, simulations with the OEF macroeconomic model suggest that different fiscal policies and monetary conditions can explain the lower growth during 1992-2001 relative to France but not relative to the other countries reviewed (Appendix In). Such simulations allow for the interaction between the government and the private sector. The specific question addressed was how would real GDP growth in Germany have fared if the country had adopted the same fiscal policy and benefited from the same change in monetary conditions as the other countries. The simulations show that if Germany had had the fiscal policies of France and the Netherlands, annual real GDP growth in Gemany might have been higher by about $1 / 3$ percentage point (Table I-15). This largely eliminates the growth gap relative to France but not the Netherlands. If Germany had had the policies and monetary conditions of Italy and the UK, real GDP growth in Germany would have been below the rate recorded during 1992-2001.

36. The dynamics of the model and the simulation exercise may miss some of the effects of different fiscal policies. First, the model might not adequately capture the longrun effects of changes in taxation on economic performance. The debate on taxation and

${ }^{20}$ On. Fund staff estimates, Germany's general government structural primary balance deteriorated from a surplus of about $53 / 4$ percent in 1990 to a deficit of $2 \frac{1}{2}$ percent of potential GDP in 1991. 
growth is not settled but the estimates that are available suggest that rising taxes and contributions in Germany would have reduced potential growth (see above, and Box). Second, it is hard to do justice with the model to the interaction of a large shock, such as unification, with a substantial change in the policy mix.

37. Even so, perhaps the conclusion to draw is that only some of Germany's slow growth relative to the other countries in 1992-2001 can be explained by fiscal policy and monetary conditions. In particular, the performances of the Netherlands and the UK were fundamentally stronger, consistent with estimates of potential output growth rates.

\section{The effects of changes in the sectoral composition of output}

38. During the 1990s, the sectoral changes in Germany were substantially larger than those in the other countries reviewed. The contraction of the industrial sector accelerated sharply during the earty 1990s, in tandem with the appreciation of the real exchange rate. In addition, the construction sector underwent a major boom-bust cycle that was related to unification. Such changes raise frictions that hold back structural labor supply and demand. Weathering them while keeping growth strong would have required a more resilient labor market.

39. Slow growth of the industry and energy sector accounts for an important part in Germany's subdued growth performance, especially during 1992-96 (Tables I-16). ${ }^{21}$ To a much lesser extent, this sector also posted below-average growth in the UK and, during the second half of the 1990s, in the Netherlands. Excluding industry and energy from value added, puts Germany's growth performance over 1992-2001 ahead of the of that of France and Italy by some $3 / 4$ percentage point but still leaves a considerable gap relative to the Netherlands and the UK (Table I- 17). ${ }_{i}^{22}$ The same calculation for 1997-2001 suggests that Germany's increase in value added remains modestly abead of that of France and Italy. However, it fails further behind that of the Netherlands and the UK — and this despite the appreciation of the pound sterling.

40. The unification-related boom only temporarily slowed the secular decline of the share of industrial output, with the subsequent downsixing greatly exceeding that in the other countries reviewed. The 1993 recession, together with the continued real appreciation of the deutsche mark, led to a major contraction of industry (Figure I-8). Simple calculations

${ }^{21}$ Part of this sector's contraction is related to outsourcing of activities to eastern European countries or to domestic firms in the services sector: between 1991-1999, the share of value added of manufacturing contracted by about $4 \frac{1}{2}$ percentage points in Germany but the share of production declined by only $2 \frac{1}{2}$ percentage points. For the other countries reviewed, the discrepancy between changes in valued added and production is much smaller.

22 Data excluding the energy sector are not available but would be interesting adjust for developintents in the UK's oil sector. 
show that over 1973-91 the size of the sector in total value added contracted by over 0.1 percentage points per annum. Allowing for a once-and-for-all reduction in the share of industry in value added by 2 percentage points in 1991-93, the 1973-91 relation continued to hold through 2001. The downsealing of industry catised job losses totaling almost 2.8 million over 1992-2001 (Table I-18). About 2.6 million of these jobs were lost during 1992-95 alone, of which more than 1 million were in the new Lander. By comparison, the losses in industry in France and Italy over 1992-2001 were about 0.5 million. In the UK they reached almost 0.9 million.

41. The contribution of the construction sector does not make much direct difference to the cross-country growth comparison for the full period 1992-2001. Upon excluding it from value added, Germany's growth is broadly on par with that of France or Italy, but relative to the Netherlands and the UK, the gaps do not differ much from those for total value added. The construction sector does make a difference in the more recent period 1997-2001, explaining some of the rising growth gap with France and accounting for almost half of the growth gap with the UK. However, as in the case of the downsizing of industry, the boom-bust in construction did lead to major shifts in employment that the labor market had to process.

42. Overall, Germany experienced significantly more structural change than the other countries in the $1990 \mathrm{~s}$. The standard deviation of sectoral output growth rates was highest in Germany, reaching 2.8 percent, about 17 percent higher than in the high-growth (Table 1-19). And the standard deviation of sectoral employment growth averaged 3.8 percent over 1992-2001, exceeding that of the UK by some 20 percent. Finally, the ratio of the standard deviations of sectoral employment and output growth rates was also highest in Germany. ${ }^{23}$

43. In sum, the German labor market processed considerable change, suggesting that the wage bargaining system and employment protection legislation might, at this stage, not be the binding constraint on a better growth performance. Instead, potential labor resources have been siphoned off into long-term unemployment and eariy retirement by the welfare system, thereby dragging down Germany's growth performance. However, the sectoral changes are slowing and this may set the scene for higher growth in the future.

\section{Integrating the new Länder}

44. Eastern Germany's income catch-up with the west has been impressive, considering the findings in the literature on convergence and the performance of selected eastern European countries. However, it has aiso been disappointing in one

${ }^{23}$ A caveat to this analysis is that the employment figures come from the labor survey. Thus they do not reflect changes in hours worked. Unfortunately, sectoral data on hours worked were available only for a subset of the countries reviewed here. 
dimension: the utilization of labor. The unemployment rate in the new Länder is more than double that in the western Länder. This is partly a legacy of overly rapid wage growth at the beginning of the decade - or equivalently the decline in structural labor supply that slowed the contribution of labor to growth.

45. For a broad sample of advanced and developing countries, Barro and Sala-îMartin (1995) find that per capita incomes converge at a rate of 3 percent per annum, holding various "other variables" (e-g., human capital, political stability, and the size of government) constant in per capita terms. ${ }^{24}$ Following unification, the new Länder latgely adopted West Germany's institutions and received substantial support for infrastructure and purchasing power from the west. Thus the "other variables" should, if anything, have contributed to a higher than 3 percent rate of productivity convergence, considering further that the new political and legal environment should have fostered investment in the east. But in other respects, unification might also have put eastern Germany at a disadvantage relative to an emerging market country. In particular, the west made for an attractive emigration target and the east bad to adopt a tax and benefit system as well as labor market regulation that have stymied incentives to work and accumulate capital.

46. The rate of income convergence of the new Länder has far outstripped the theoretical pace. In 1991, real GDP per employed in the east stood at 35 percent of the west, implying that productivity should have grown at least 2 percentage points faster annually than in the west, according to the Barro and Sala-1-Martin findings. In fact, productivity grew some 7.3 percentage points faster than in the west over 1992-2001 to reach 71 percent of the western level in 2001 (Figure 1-9). Only to a minor extent was this performance a reflection of employment losses: per capita GDP in the new Länder also started from 35 percent of the level in the old Länder to climb to 64 percent. ${ }^{25}$ As a result, per capita GDP in eastern Germany is now only about 6 percent lower than in Portugal. None of the Eastern European countries reviewed here-the Czech Republic, Hungary, and Poland-achieved such a rapid improvement in productivity and GDP per capita. In the Czech Republic, the most productive among the eastern European countries reviewed, GDP per capita it is still 13 percent lower than in the new Länder.

47. The productivity and per capita GDP gains in the new Länder were concentrated in the early years of unification, raising the question of whether

\footnotetext{
${ }^{24}$ This is faster than the result cited earlier for the advanced European economies. But the new Länder in 1991 could not be compared to any regions within the advanced European economies. A 3 percent convergence rate means that 3 percent (not 3 percentage points) of the per capita income gap is eliminated each year.

${ }^{25}$ By contrast, per capita GDP in the south of Italy (Mezzogiorno), which is often compared to east Germany-has fluctuated around 55 percent of the level in the center-north during 1980-97.
} 
convergence might be stalling. Productivity in the east has only grown 1 percentage point faster than in the west over 1997-2001. However, a lower rate of convergence is partly natural: in terms of productivity and per capita GDP the new Länder now compare to the less-rich ađvanced European regions. Using Barro and Sala-î-Martin's results for such regions, which may now be more applicable, productivity growth in the east should now be higher relative to the west by only 0.3 percentage points a year.

48. Moreover, adjusting for special developments in the construction sector, which were driven by the need to improve the housing stock and infrastructure in the new Länder, income convergence continues. A construction boom at the beginning of the $1990 \mathrm{~s}$ partly explains the rapid convergence initially and the recent slowdown (Figure I-10). By contrast, the manufacturing sector-where productivity is easiest to measure-has continued to post an impressive performance: even over 1997-2001, productivity converged at a rate of almost 4.8 percentage points per annum while employment expanded. In short, the forces of convergence remain alive, even if the rapid gains during the early years following unification can no longer be expected.

\section{The new Länder have considerably reduced their dependence on transfers from} the west. In 1999, per capita disposable income in the new Lander amounted to 82 percent of the level in the old Länder; ${ }^{26}$ for nominal GDP, the ratio was 64 percent. The same ratios for 1991 were 57 percent and 35 percent, respectively. According to measures conventionally used in the literature on interregional income redistribution, this puts the amount of redistribution at about 25 percent of nominal GDP in per capita terms in 1999, down from over 60 percent in 1991. The amount of redistribution is thus no longer extraordinaty by international standards. A number of papers have examined redistribution across regions within Canada, France, Italy, the UK, and the US. The lowest amounts of redistribution are found for the US, with most estimates in the range of 10-15 percent of gross state product. ${ }^{27}$ The highest estimates of redistribution are found for France and reach almost 40 percent (Mélizz and Zumer, 1998). What is unusual in the case of eastern Germany is that the poor regions are concentrated in one area and that the income gap is large.

\footnotetext{
${ }^{26}$ Adjusting for differences in purchasing power, that level rises to 89 percent (see IFO Schnelldiesnt, 15/2002).

${ }^{27}$ But some, including von Hagen (1992) and Sachs and Sala-î-Martin (1992) find larger estimates.
}

${ }^{28}$ In the US, some 10 states have personal incomes per capita of 80 percent or less of the US average, with the lowest ranking state reaching some 70 percent. Thus, in terms of personal income per capita, the gaps are a smaller than for GDP per capita in eastern/western Germany. In Italy, however, the income gaps between north and south are larger than those between east and west in Germany. 
50. From one perspective the contribution of the new Länder to economic growth in Germany has been disappointing: unemployment rates of 15-20 percent in the east testify to a large pool of unused resources. This is a legacy of overly rapid convergence of eastern wages toward western levels. Unit labor costs stood almost 50 percent above the western level in 1991 (Figure I-11). Today eastern unit labor costs in the economy excluding the primary sector and in manufacturing still remain considerably higher, albeit by a much smaller margin than 50 percent.

51. The employment experience in the new Länder exemplifies the interaction of Germany's welfare benefit system with shocks. With benefits linked to past wages, the system provided an incentive for unions to push for large wage increases when faced with the inevitable restructuring of east Germany's uncompetitive industry. And an eastern entrepreneurship that bad no ownership stake in its companies was only too ready to cave in to demands. The result exacerbated job destruction.

52. To cut unemployment, further wage moderation in the new Länder is warranted, although recent developments show that some equilibrating mechanisms are at work.

Employers are increasingly leaving their associations, and hence the collective bargaining "table", to strike better pay deals. Moreover, many of the remaining collective wage bargaining agreements in the east now contain opening clauses that allow lower pay or longer working hours to secure jobs.

\section{E. Economic Adjustment: The Road Ahead}

53. Many points of the above analysis suggest that the low growth rate in 1992-2001 ought not to be representative of Germany's medium-term outlook. Assuming per capita TFP were to grow by at least at 1 percent per annum, the contribution of the capital stock to growth was at least $1 / 2$ percent per annum, and-thanks to the wage moderation of 1996 2000 -the contribution of labor was small but positive, per capita potential output growth woulg be $13 / 4$ percent. But absent policies to sustain wage moderation, labor's contribution would drop close to zero, the projected growth rate for the working-age population, once unemployment closes in on the estimated natural rate of 7 percent.

54. However, the persistent, current slowdown dampens confidence in the view that Germany has put its decade of slow growth behind it. At this stage, the depth of the slowdown relative to most of the comparator countries chosen here appears to be more a matter of somewhat earlier timing as well as some specific factors: 
- Investment in machinery and equipment had peaked earlier than in the other countries, partly because tax changes prompted entrepreneurs to advance expenditure on machinery and equipment to a record level in 2000 . At the same time, the postunification slump in construction continued to exacerbate the fall in total investment.

- Unlike elsewhere, residential real estate prices have not buffered the effect of the decline in the stock market on investment and consumption (Figure I-12). ${ }^{29}$

- Structural changes in the German banking system are perhaps holding back the supply of funding. ${ }^{30}$

- As in the past, Germany, along with the Netherlands, was faster and perhaps more severely affected by the $3 \frac{1}{2}$ percentage point slowdown in US GDP growth in 2001. Econometric evidence for the 1990s suggests that the GDP growth rate in Germany and the Netherlands falls by some 32-43 percent of this amount in two quarters and by $42-62$ percent in four quarters, with the Netherlands at the upper end of the ranges (Figure I-13). In France, the adjustment after four quarters is similar, but it is smaller after two quarters. In Italy and the UK the crop after both two and four quarters is considerably lower. Except for Italy, this is consistent with the countries' shares in merchandise exports. Italy, however, stands out in that it is much less involved with the US economy via foreign direct investment. ${ }^{31}$ For the UK, the country's smaller exposure to oil price changes might have mattered.

\begin{tabular}{|c|c|c|c|c|}
\hline \multicolumn{5}{|c|}{$\begin{array}{l}\text { Fixud Investment, 1992-2001 } \\
\text { (Growth rates, in percent) }\end{array}$} \\
\hline & France & Germany & Jtaly & $\mathrm{UKK}$ \\
\hline \multicolumn{5}{|c|}{ Outslde Constructlon } \\
\hline $1992-2000$ & 33.8 & 14.3 & 33.8 & 71.9 \\
\hline $199-7-2000$ & 30.7 & 33.0 & 30.4 & 40.1 \\
\hline 2000 & 6.7 & 9.7 & 7.1 & 6.1 \\
\hline $200 \mathrm{l}$ & 3.5 & -3.1 & 1.5 & 0.7 \\
\hline \multicolumn{5}{|c|}{ Construction } \\
\hline $1992-2000$ & -3.4 & 9.8 & -4.3 & 14.9 \\
\hline $1997-2000$ & 9.5 & -3.6 & 6.2 & 12.3 \\
\hline 2000 & 5.6 & -2.1 & 5.6 & 0.8 \\
\hline 2001 & 1.9 & -5.5 & 3.7 & 2.3 \\
\hline
\end{tabular}

Source: Eurostat and staff calculations.

Exports of Goods (In percent of GDP)

\begin{tabular}{lr}
\hline & 2001 \\
\hline France & 22.0 \\
Germany & 30.9 \\
Italy & 22.2 \\
UK & 19.4 \\
\hline
\end{tabular}

${ }^{29}$ However, an increase in West Germany's population by about 5 million during 1988-93, or by about 8 percent, had earlier given German households stronger gains on their real estate than those in most of the other countries reviewed (see Bundesbank, Monthly Report, January 2002).

${ }^{30}$ See Chapter III.

${ }^{31}$ In 2001 , the US foreign direct investment positions in France, Germany, Italy, the Netherlands, and the UK amounted to US\$38 billion; US\$61 billion; US $\$ 24$ billion; US $\$ 132$ billion; and US $\$ 249$ billion, respectively. The positions of these countries in the US were, respectively: US\$147 billion; US\$153 billion; US\$6 billion; US\$158 billion; and US\$218 bilition (Borga and Yorgason, 2002). 
- The structural developments in the labor market continued to play a role. Given the lags with which wage moderation affects labor supply, the preceding upswing was less job-rich in Germany than in the other countries reviewed (see Table $1-4$ and $\mathrm{IMF}$, 2001). With factor proportions still adjusting to a lesser extent to wage moderation than in the other countries reviewed, employment and employees' real disposable incomes failed to accelerate, despite a sizable tax cut in 2001 .

Germany: Real Disposable Income Growth, 1996-2002

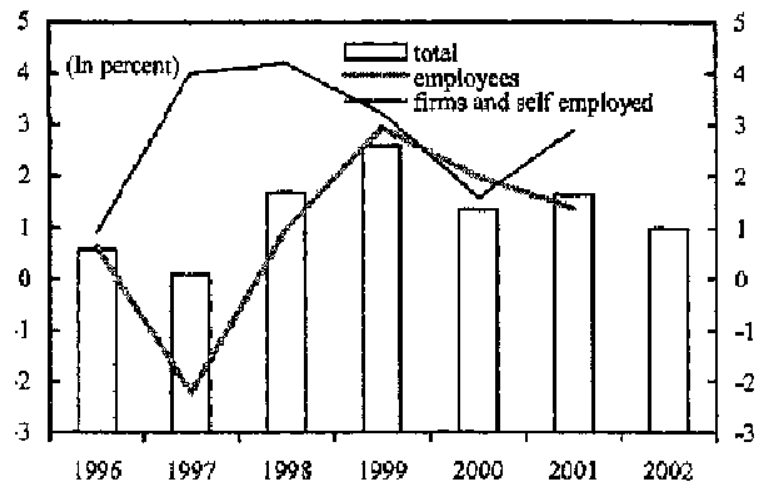

55. And absent reforms, the economy is likely to continue to lack resilience in the face of shocks. The 1990s marked a decade of major shocks and adjustments in the German economy, unlike in any of the other countries reviewed. ${ }^{32}$ A specific problem in Germany has been the interaction of the welfare benefit system with large economic shocks. Without change, there would be a risk that shocks would once again lead to an upward ratcheting of unemployment. Ljungqvist and Sargent (1998) model the interaction of shocks with benefit systems for the jobless. Shocks destroy employment and the jobless lose firm-specific and (potentially) industry-specific human capital. ${ }^{33}$ Having suffered human capital losses, the jobless would have to agree to a wage cut to find a new job. However, in Germany, the incentive to do so is limited by generous benefits that are a function of previous earnings (Grund (1999) and Burda and Mertens (2001)). As a result, shocks cause an increase in the duration of unemployment spells that slows job creation and real GDP growth.

\section{Finally, although the effects of the unification-related shocks should be} unwinding, reforms are needed to deal with the "stock problem" posed by the low employment rate of older workers and workers in the new Länder. While various measures should be contemplated - including looser employment protection legislation, more scope for temporary employment, and better job matching-a reform of benefits for the jobless is the perhaps the single most crucial step. Meanwhile, the effect of measures should

${ }^{32}$ Blanchard and Wolfers (1999) show how shocks and institutions interacted to raise European unemployment. Their evidence suggests that a country that suffers larger shocks needs more flexible institutions to avoid posting larger employment losses and lower growth.

${ }^{33}$ Wasmer (2002) presents a model according to which higher job protection legislationthis would be the case for Germany, France, and Italy in the sample of countries reviewed here-leads to more investment in firm-specific human capital. Workers in such countries would suffer larger human capital losses on entering unemployment. 
be leveraged with reforms that foster productivity growth, by enhancing product market competition and improving the quality of education. 


\section{Identifying Labor Supply and Demand}

\section{Labor supply}

57. Labor supply can be characterized by a wage-setting relationship relating real consumption wages to unemployment rates. ${ }^{34}$ Define the real effective consumption wage as $\omega_{c}$, with $\omega_{c}=\log \left(w_{c} / a\right)$, then the wage-setting relation is given by $\omega_{c}=-\beta U-Z$ where $U$ stands for the unemployment rate. The relation assumes reservation (and thus actual) wages rise with productivity: history clearly suggests no relation between productivity and employment in the long run. However, if workers' aspirations lag reality, reservation wages are unlikely to adjust instantaneously with TFP, giving rise to labor supply shocks in this model.

58. Is it sensible to build on such a wage relation? One perspective is offered by the job matching approach and wage bargaining. ${ }^{35}$ Workers cannot costlessly relocate to find a new job nor can they costlessly and instantaneously be replaced by their employers. In a depressed labor market, workers will settle for a wage close to the reservation wage because it is hard to find a job elsewhere. The opposite holds for a booming labor market. Alternatively, models focus on the firm-worker relationship, arguing that wages affect productivity. Firms may want to pay more to workers than their reservation wage to economize on turnover costs, motivate greater effort, or for social considerations, such as fairness. ${ }^{36}$ The following equation can thus be taken to characterize the evolution of labor supply over time: $\Delta Z_{t}=-\Delta\left[\omega_{t}+\beta U_{f}\right]$.

59. With data for $U$, w, and $\alpha$ available, while $a$ can be obtained from the growth accounting exercise, assessing labor supply developments requires an estimate for the parameter $\beta$. Blanchflower and Oswald (1995) investigate the relation between real wages and unemployment for three out of the five countries considered here (Italy, the Netherlands, and the UK). Using internationally broadly comparable microeconomic data, they estimate a cross-sectional earnings equation for each country, in which, together with the usual set of control variables, ${ }^{37}$ the regional unemployment rate is entered as an explanatory variable. They demonstrate that there appears to be an empirical regularity in international pay and unemployment data, whereby estimates of the unemployment elasticity of pay cluster around -0.1 . This result is broadly consistent with $\beta=1$, considering the average unemployment rates

\footnotetext{
${ }^{34}$ See Blanchflower and Oswald (1994) or Blanchard and Katz (1997).

${ }^{35}$ Pissarides (1990).

${ }^{36}$ See, for example, Shapiro and Stiglitz (1984); Katz (1986); and Akerlof and Yellen (1990).

${ }^{37}$ These vatiables include dummies for the industry and region in which a worker is employed; his or her gender, marital status, experience, schooling, rank, and union status.
} 
in the countries, implying an increase in unemployment by 1 percentage point decreases effective wages by 1 percent. Other studies have found estimates for $\beta$ close to 2 but qualitatively that difference is not important.

\section{Labor demand}

60. The specification of labor demand begins with the following CES-type production:

$$
y=A\left[\alpha(a n)^{\frac{\sigma-1}{\sigma}}+(1-\alpha) k^{\frac{\sigma-1}{\sigma}}\right]^{\frac{\sigma}{\sigma-1}},
$$

where $n$ stands for labor, $k$ for capital, and $\sigma$ for the (constant) elasticity of substitution between effective labor ( $a n$ ) and capital. To find labor demand, set the marginal product of labor equal to the real effective product eompensation $\left(\left(1+t_{p}\right) w / a\right)$ multiplied by a mark-up $(1+\mu)$.

$$
\frac{\partial y}{\partial n}=(1+\mu)\left(1+t_{p}\right) w,
$$

with the mark-up resulting, for example, from "efficient bargaining."38 Take natural logarithms and rearrange to find:

$$
\log (1+\mu)=\log \alpha-\log \left(1+t_{p}\right)-\log (w / a)-\frac{1}{\sigma} \log \left(\frac{a n}{y}\right)
$$

61. There are three perspectives to changes in labor demand. A technology-driven decline in labor demand can be thought of as a drop in $\alpha$ for unchanged $\mu$. Aiternatively, a drop in demand because of less union bargaining power can be thought of as an increase in $\mu$ for given $\alpha$. And a drop in the demand for labor because of a rise in payroll taxes can be thought of an increase in the payroll tax rate $t_{p}$, with $\alpha$ and $\mu$ unchanged. Observationally these changes in labor demand $L^{d}$ are equivalent and their change over time is given by:

$$
\Delta I_{t}^{d}=\Delta\left[\log \left(w_{t} / a_{t}\right)+\frac{1}{\sigma} \log \left(\frac{a_{t} n_{t}}{y_{t}}\right)\right] .
$$

62. Conveniently, for $\sigma \approx 1$, the evolution of labor demand is given simply by the natural logarithm of the labor share in income. Moreover, the effect of payroll taxes on labor demand can be approximated by the percentage point change in the effective tax rate. Note that equations (3) and (4) are correct only in the absence of costs of adjusting factor proportions.

${ }^{38}$ See Rotemberg and Woodford (1999). With efficient bargaining, firms employ more workers than they would really want at a given wage. The marginal product of labor is set equal to the reservation wage of the worker; however, the wage paid is a weighted average of the marginal and average product of labor: here this would imply $\mu<1$. 
If it is costly for firms to adjust factor proportions, an increase in the wage will be associated with little contemporaneous change in (an/k) and thus (an/y); this in turn will lead to a decrease in the measured wedge. To allow for adjustment costs in factor proportions Blanchard (1998) proposes to replace $\log (w / a)$ with $\log \left(w_{t}^{*}\right)=0.8 \log w_{t-1}^{*}+0.2 \log \left(w_{t} / a_{t}\right)$ in computing $\mathrm{L}^{\mathrm{d}}$, implying a mean lag in the adjustment of factor proportions of four years. ${ }^{39}$

${ }^{39}$ The starting value for $w^{\text {* }}$ is set equal to $w / a$ for 1975

CInternational Monetary Fund. Not for Redistribution 


\section{Macroeconomic Model Simulations}

63. The simulations were carried out with the help of the Oxford Economic Forecasting (OEF) model. The OEF model is a mainstream economic model, situated in the middle ground between purely statistical models of the economy (e.g, vector autoregressions (VAR)) and computable general equilibrium models (CGEMs). Like CGEMs, the model imposes certain parameter restrictions based on theoretical priors. However, like VARs, it also estimates other parameter coefficients with country data to ensure that the model does well in reproducing the short-run behavior of key variables. The model exhibits Keynesian features in the short run and neoclassical ones in the long run. Its key characteristics are: (i) countries have a natural long-run growth rate but aggregate demand need not match supply in the short run; (ii) monetary policy, which is characterized by a Taylor rule, cannot affect output in the long run; (iii) consumption is a function of real incomes, real financial wealth, the real interest rate, and inflation; (iv) investment equations are influenced by qtheories, in which investment is a function of its opportunity cost after taking taxes into account, as well as accelerator effects; and (v) the country is small with terms of trade determined and exports a function of world demand and extemal demand. The model is backward-looking, with equations featuring an error correction component. In the simulations, the response of monetary policy to fiscal policy is muted.

64. The specific question addressed was how would real GDP growth in Germany have fared if the country had adopted the same fiscal policy and benefited from the same change in monetary conditions as the other countries:

- A "same fiscal policy" was defined as a policy that would have imparted the same fiscal impulse to the economy as in the other countries reviewed. ${ }^{40}$ Because the actual fiscal adjustment in Germany was largely achieved by revenue increases, the simulated change in the impulse to make it match that in the other countries entirely took the form of a higher or lower tax bill.

- For Germany, the fiscal balance was adjusted for the unification-related expenditure by the major public enterprises - the post and telecommunications company and the railway company - that were outside the general government sector. Together with the operations by the Treuband Anstalt, borrowing by the public enterprises increased the fiscal deficit by some $1 \frac{1}{2}$ percentage points of GDP during 1991-95 (see Tables I-20 and I-21). Much of this borrowing had been eliminated or assimilated into the general government by 1995 .

\footnotetext{
${ }^{40}$ The fiscal impulse is measured as the change in the primary structural general government balance, rather than the overall structural balance, as changes in the interest bill are covered under the calculations to assess how the economy would have evolved if it had it benefited from the sarne interest rate changes as in the other countries. In the OEF model simulations, the income tax rate was allowed to adjust by removing "fixes."
} 
- The "same change in monetary conditions" was defined as the same change in the short-term real interest rate. The cumulative differences in real interest rate changes between countries were relatively small over 1992-2001. Both interest rate levels and changes matter for investment. However, to the extent that the stock of capital had adjusted to a level consistent with interest rates prevailing in 1990-91, interest rate changes may be more relevant. A more fundamental problem is that the simulations should realiy use ex ante rather than the observed ex post real interest rates: higher ex post real interest rates in Italy during the early 1990 s partly reflected market views about the probability of disinflation failure.

- The real exchange rate, the other determinant of monetary conditions, was ignored. In real effective terms, the deutsche mark appreciated by about 20 percent in the first half of the 1990s. By contrast, the French franc and the Dutch guilder appreciated between 0-5 percent, while the lira and pound depreciated to different extents. EU (2002a) argues that the effects of the appreciation during the first half of the 1990s should have been unwound by now. And pre-EMU versions of the OEF model suggest that real exchange rate movements have only a small, short-run effect on GDP in Germany. A key issue is the interaction of monetary policy and the exchange rate: in the OEF model, a 5 percent appreciation of the exchange rate triggers a 0.5 percentage point cut in interest rates after one year. Thus, GDP drops only by 0.2 percentage points initially but returns to the baseline after three years. ${ }^{41}$ However, the real exchange rate powerfully affects output in the industrial sector in the OEF model, an issue which is discussed further in the main text. ${ }^{42}$

\footnotetext{
${ }^{41}$ If interest rates were kept unchanged, the loss in output would be 0.4 percentage point.

${ }^{42}$ See also Chapter II, which discusses external competitiveness.
} 


\section{References}

Akerlof, George A and Janet L. Yellen (1990), The Fair Wage-Effort Hypothesis and Unemployment," Quarterly Journal of Economics, vol. 105, pp. $255-83$.

Argyle, M. (1987), The Psychology of Happiness, Methuen, London.

Barro, R. J. and X. Sala-î-Martin (1995), Economic Growth, McGraw-Hill, New York.

Baily, M. N. (2002), "The New Economy: Post Mortem or Second Wind?," Journal of Economic Perspectives, vol. 16, pp. 3-22.

Bassanini, A. and E. Ernst (2002), "Labour Market Institutions, Product Market Regulation, and Innovation: Cross-Country Evidence," Economics Department Working Papers, No. 316, OECD.

Bassanini, A., Scarpetta S,. and P. Hemmings (2001), "Economic Growth: The Role of Policies and Institutions," Economics Department Working Papers, No. 283, OECD,

Blanchard and Katz (1997), "What We Know and Do Not Know About the Natural Rate of Unemployment," Journal of Economic Perspectives, vol. 11 (1), pp. 51-72.

Blanchard, O. (1998), "Revisiting European Unemployment, Capital Accumulation, and Factor Prices," mimeo, MIT, Cambridge (MA).

Blanchard, O. and J. Wolfers (1999), "The Role of Shocks and Institutions in the Rise of European Unemployment: the Aggregate Evidence," NBER Working Paper No. 7282.

Blanchflower, D. and A. Oswald (1994), The Wage Curve, MIT Press, Cambridge (MA).

Blanchflower, D. and A. Oswald (1995), "International Wage Curves", in Freeman and Katz (eds.), Differences and Changes in Wage Structures, University of Chicago Press, Chicago.

Borga, M. and D. R. Yorgason (2002), Direct Investment Positions for 2001: Country and Industry Detail, Bureau of Economic Analysis.

Bundesbank (2000), Monthly Report, August. (2001), Monthly Report, July.

Burda, M. C. and J. Hunt (2001), "From Reunification to Economic Integration: Productivity and the Labor Market in East Germany", Brookings Papers on Economic Activity (2), pp. 1-92. 
Burda, Michael C. and Antje Mertens (2001), "Estimating Wage Losses of Displaced Workers in Germany", Labour Economics Vol. 8, pp. 15-41.

Calmfors, Lars and John Driffill (1988), "Bargaining Structure, Corporatism, and Macroeconomic Performance," Economic Policy, vol. 6, pp. 14-61.

Edison, H. and T. Sløk (2001a), "Wealth Effects of the New Economy", IMF Working Paper WP/01/77.

(2001b), "New Economy Stock Valuations and Investment in the 1990", IMF Working Paper WP/01/78.

European Union (2002a), "Germany's Growth Performance in the 1990s," Economic Paper No. 170, Directorate General Economic and Financial Affairs, Brussels.

(2002b), "Public Finances in EMU 2002," European Economy, No. 3., Directorate General Economic and Financial Affairs, Brussels.

Grund (1999), "Stigma Effects of Layoffs? Evidence from German Micro-Data," Economics Letters, Vol. 28, pp. 51-75.

IMF (2000), Germany - Selected Issues, IMF, Washington DC.

(2001), France, Germany, Italy and Spain--Selected Issues-Rules-Based Fiscal Policy and Job-Rich Growth in Euro-Area Countries, IMF, Washington DC.

(2002), The Kingdom of the Netherlands-Selected Issues, IMF, Washington DC.

Jorgensen, D, W., 1971, "Econometric Studies of Investment Behavior: A Survey," Journal of Economic Literature, vol. 9, pp. 1111-47.

Katz, L. (1986), "Efficiency Wage Theories: A Partial Evaluation," in S. Fischer (ed) NBER Macroeconomics Annual 1986, Cambridge, Mass. MIT Press.

Layard, R. and S. Nickell (1999), "Labor Market Institutions and Economic Performance," in O. Ashenfelter and D. Card (eds), Handbook of Labor Economics, Elsevier.

Layard, R., Nickell, S., and R. Jack man (1991), Unemployment, Oxford University Press.

Ljungqvist, Lars and Thomas J. Sargent (1998), "The European Unemployment Dilemma," Journal of Political Economy, vol. 106, pp. 514-550.

McKinsey Global Institute (2001), US Productivity Growth 1995-2000, Washington DC.

Mélitz, J., and F. Zumer, 1998, Regional Redistribution and Stabilization by the Center in Canada, France, the UK, and the United States, CEPR Discussion Paper No. 1829. 
Nickell, S. J. (1996), "Competition and Corporate Performance," Journal of Political Economy, vol. 104, pp. 724-746.

Nickell, S. J, and G. Quintini, 2002, "The Recent Performance of the UK Labour Market," Oxford Review of Economic Policy, vol. 18, pp. 202-219.

Nicoletti, G., Scarpetta, S., and O. Boylaud (2000), "Summary Indicators of Product Market Regulation with an Extension to Employment Protection Legislation," Economics Department Working Papers, No. 226, OECD.

Nicoletti, G., Bassanini, A., Ernst, E., Jean, S., Santiago, P., and P. Swain (2001), "Product and Labour Market Interactions in OECD Countries," Economics Department Working Papers, No. 312 , OECD.

OECD (1999), Benefit Systems and Work Incentives, OECD, Paris.

OECD (2002), Knowledge and Skills for Life: First Results from PISA 2000, OECD, Paris.

Oxford Economic Forecasting (1996), The New Oxford World Model: An Overview.

Pissarides, C. A. (1990), Equilibrium Unemployment, Oxford: Basil Blackwell.

Romer, D. (1996), Advanced Macroeconomics, McGraw-Hill, New York.

Rotemberg and Woodford (1999), "The Cyclical Behavior of Prices and Costs," in J. Taylor and M. Woodford (eds.), Handbook of Macroeconomics, North Holland Elsevier, New York.

Sala-î-Martin, X. and J. Sachs, 1992, AFiscal Federalism and Optimum Currency Areas: Evidence for Europe from the United States, in Establishing a Central Bank: Issues in Europe and Lessons from the United States, ed. by M.B. Canzonieri, V. Grilli, and P.R. Masson (Cambridge, Massachusetts: Cambridge University Press).

Scarpetta, S., Bassanini, A., Pilat, D., and Paul Schreyer (2000), "Economic Growth in the OECD Area: Recent Trends at the Aggregate and Sectoral Level," Economics Department Working Papers, No. 248, OECD.

Serres de, A., Scarpetta, S., and C. de la Maisonneuve (2002), "Sectoral Shifts in Europe and the United States: How They Affect Aggregate Labour Shares and the Properties of the Wage Curve," Economics Department Working Papers, No. 326, OECD.

Shapiro, C. and J. Stiglitz (1984), "Equilibrium Unemployment as a Worker Discipline Device," American Economic Review, No. 74, pp. 433-444. 
Von Hagen, J, 1992, AFiscal Arrangements in a Monetary Union: Evidence from the United States, in Fiscal Policy, Taxes, and the Financial System in an Increasingly Integrated Europe, ed. by D.E. Fair and C. De Boissieu (Boston, Massachusetts: Kluwer).

Wasmer, E., 2002, "Interpreting Europe and US Labor Markets Difference: The Specificity of Human Capital Investments," IZA Discussion Paper No. 549.

Watson, C., Bakker, B., Martijn, J., and I. Halikias (1999), “The Netherlands: Transforming a Market Economy," Occasional Paper, No. 181, IMF, Washington D.C. 
Table I-1. Gernany's Economic Performance, 1992-2001

(Geometric average in percent, unless otherwise indicated)

\begin{tabular}{|c|c|c|}
\hline & $1997-2001$ & $1992-2001$ \\
\hline \multicolumn{3}{|c|}{ Per capita real GDP growth $1 /$} \\
\hline France & 2.6 & 1.7 \\
\hline Germany & 1.8 & 1.3 \\
\hline West & 2.0 & 1.1 \\
\hline Italy & 2.1 & 1.6 \\
\hline Netherlands & 2.9 & 2.3 \\
\hline Ünited Kingdom & 2.3 & 2.3 \\
\hline \multicolumn{3}{|c|}{ Real GDP growth, business sector } \\
\hline France & 3.1 & 2.0 \\
\hline Germany & 2.1 & 1.8 \\
\hline Italy & 2.3 & 1.9 \\
\hline Netherlands & 3.4 & 2.9 \\
\hline United Kingdom & 3.0 & 3.1 \\
\hline \multicolumn{3}{|c|}{ Potential GDP growth per capita, OECD 1/ } \\
\hline France & 1.8 & 1.6 \\
\hline Germany & 1.7 & 1.7 \\
\hline Italy & 2.3 & 1.8 \\
\hline Netherlands & 2.9 & 2.5 \\
\hline United Kingdom & 2.0 & 2.1 \\
\hline \multicolumn{3}{|c|}{ Potential GDP growth per eapita, IMF I/ } \\
\hline France & 1.9 & 1.7 \\
\hline Germany & 1.9 & 1.7 \\
\hline Italy & 1.9 & 1.8 \\
\hline Netherlands & 2.3 & 2.3 \\
\hline United Kingdom & 1.9 & 2.2 \\
\hline Ouput gaps, OECD $2 /$ & 1991 & 2001 \\
\hline France & 0.2 & 0.5 \\
\hline Germany & 1.2 & -1.4 \\
\hline Italy & -0.5 & -1.4 \\
\hline Netherlands & 1.3 & 0.0 \\
\hline United Kingdom & -3.9 & 0.1 \\
\hline Ouput gaps, IMF $2 /$ & 1991 & 2001 \\
\hline France & 0.6 & 0.0 \\
\hline Germany & 2.9 & -1.0 \\
\hline Italy & 1.1 & -1.0 \\
\hline Netherlands & 0.8 & 1.3 \\
\hline United Kingdom & -0.1 & 0.4 \\
\hline
\end{tabular}

Sources: OECD Economic Outlook database; and IMF WEO database.

1/ Based on working age population.

$2 /$ In percent of potential output. 
Table I-2. The Years Preceding German Unification, 1989-1991

(Geometric average, uniess otherwise indicated)

\begin{tabular}{|c|c|c|}
\hline & $1989-1991$ & $1989-2001$ \\
\hline \multicolumn{3}{|l|}{ Real GDP growth } \\
\hline France & 2.6 & 2.1 \\
\hline Germany & 4.7 & 2.2 \\
\hline Italy & 2.1 & 1.7 \\
\hline Netherlands & 3.7 & 3.0 \\
\hline United Kingdom & 0.5 & 2.2 \\
\hline \multicolumn{3}{|c|}{ Private real consumption growth } \\
\hline France & 2.2 & 1.8 \\
\hline Germany & 4.0 & 2.1 \\
\hline Italy & 2.9 & 1.8 \\
\hline Netherlands & 3.7 & 3.0 \\
\hline United Kingdom & 0.9 & 2.8 \\
\hline \multicolumn{3}{|c|}{ Real gross fixed capital formation } \\
\hline France & 3.1 & 2.3 \\
\hline Germany & 6.9 & 2.1 \\
\hline Italy & 3.1 & 2.0 \\
\hline Netherlands & 2.2 & 2.9 \\
\hline United Kingdom & -1.8 & 2.1 \\
\hline \multicolumn{3}{|c|}{ Real total domestic demand } \\
\hline France & 2.4 & 1.9 \\
\hline Germany & 3.8 & 1.8 \\
\hline Italy & 2.6 & 1.6 \\
\hline Netherlands & 3.3 & 2.8 \\
\hline United Kingdom & 0.1 & 2.4 \\
\hline \multicolumn{3}{|c|}{ Current account balance (in percent of GDP) if } \\
\hline France & -0.6 & 1.0 \\
\hline Germany & 2.3 & 0.1 \\
\hline Italy & -1.6 & 0.4 \\
\hline Netherlands & 3.1 & 3.9 \\
\hline United Kingdom & -3.7 & -1.9 \\
\hline
\end{tabular}

Sources: WEO database; and SM/94/213 for Germany in 1989-91.

Note: Data for 1989-91 are for West Germany only. Data for 1989-2001 are for West Germany for 1989-91 and unified

Germany for 1992-2001.

1/ Arithmetic average. 
Table [-3. Germany's Labor Market Perfornance, 1992-2001

(Arithmetic average in percent, unless otherwise indicated)

\begin{tabular}{|c|c|c|c|}
\hline & 1991 & 1996 & 2001 \\
\hline \multicolumn{4}{|c|}{ Unemployment rate } \\
\hline France & 9.4 & 12.1 & 8.7 \\
\hline Getmany & 5.4 & 8.5 & 7.4 \\
\hline West & 4.2 & 7.2 & 6.4 \\
\hline Italy & 8.6 & 11.7 & 9.6 \\
\hline Netherlands & 5.4 & 6.6 & 2.2 \\
\hline United Kingdom & 8.2 & 7.9 & 5.1 \\
\hline \multicolumn{4}{|c|}{ Natural unemploynent rate, OECD } \\
\hline France & 9.7 & 9.9 & 9.3 \\
\hline Germany & 6.7 & 7.2 & 7.3 \\
\hline Italy & 9.3 & 10.2 & 9.2 \\
\hline Netherlands & 7.1 & 5.3 & 4.0 \\
\hline United Kingdom & 8.2 & 6.3 & 5.5 \\
\hline \multicolumn{4}{|c|}{ Natural unemployment rate, IMF } \\
\hline France & 9.2 & 9.7 & 8.8 \\
\hline Germazy & 72 & 7.5 & 7.2 \\
\hline Italy & 11.0 & 9.7 & 8.7 \\
\hline Netherlands & 5.8 & 5.5 & 3.9 \\
\hline United Kingdom & 8.2 & 7.0 & 5.5 \\
\hline \multicolumn{4}{|l|}{ Hours worked 1/ } \\
\hline France & 106.4 & 104.0 & 101.0 \\
\hline Gemany & 100 & 97.7 & 95.4 \\
\hline Italy & 107.9 & 105.8 & 105.7 \\
\hline Netherlands & 92.3 & 89.7 & 86.9 \\
\hline United Kingdom & 114.4 & 112.4 & 110.4 \\
\hline \multicolumn{4}{|c|}{$\begin{array}{l}\text { Employment ratio (in percent of } \\
\text { 15-64 years old; EUROSTAT) }\end{array}$} \\
\hline France & 60.1 & 59.7 & 62.7 \\
\hline Gemany & 66.6 & 64.1 & 65.7 \\
\hline Taly & 52.3 & 50.6 & 54.5 \\
\hline Netherlands & 63.7 & 65.4 & 74.1 \\
\hline United Kingdom & 68.1 & 68.7 & 71.6 \\
\hline \multicolumn{4}{|c|}{ Hours adjusted employment ratio $2 !$} \\
\hline France & 64.0 & 63.5 & 66.4 \\
\hline Germany & 66.6 & 64.1 & 65.7 \\
\hline Italy & 56.4 & 54.8 & 60.3 \\
\hline Netherlands & 58.8 & 60.1 & 67.5 \\
\hline United Kingdom & 77.9 & 79.0 & 82.8 \\
\hline
\end{tabular}

Sources: OECD Economic Outlook and Analytical databases; EUROSTAT; and IMF, World Economic Outlook database.

I/ Average hours worked by employees in the business sector; in percent of Gerraany.

$2 /$ Employment rate multiplied by index of hours worked. 
Table I-4. Germany: Growth Accounting, 1992-2001

(Geometric averages in percent, unless otherwise noted)

\begin{tabular}{|c|c|c|}
\hline & $1997-2001$ & $1992-2001$ \\
\hline \multicolumn{3}{|c|}{ Business GDP growth } \\
\hline France & 3.1 & 2.0 \\
\hline Germany & 2.1 & 1.8 \\
\hline Italy & 2.3 & 1.9 \\
\hline Netherlands & 3.4 & 2.9 \\
\hline United Kingdorn & 3.0 & 3.1 \\
\hline \multicolumn{3}{|c|}{ Total factor productivity contribution } \\
\hline France & 1.2 & 0.9 \\
\hline Germany & 1.0 & I. 1 \\
\hline Italy & 0.2 & 0.8 \\
\hline Netherlands & 0.9 & 1.1 \\
\hline United Kingdom & 1.1 & 1.5 \\
\hline \multicolumn{3}{|l|}{ Labor contribution } \\
\hline France & 0.8 & 0.1 \\
\hline Germany & 0.4 & -0.1 \\
\hline Italy & 0.8 & -0.1 \\
\hline Netherlatids & 1.3 & 0.8 \\
\hline \multicolumn{3}{|l|}{ Of which: Hours } \\
\hline France & -0.4 & -0.3 \\
\hline Germany & -0.3 & -0.3 \\
\hline Italy & 0.0 & -0.1 \\
\hline Netherlands & -0.4 & -0.4 \\
\hline United Kinglom & -0.3 & -0.3 \\
\hline \multicolumn{3}{|c|}{ Capital contribution } \\
\hline France & 1.0 & 1.0 \\
\hline Germany & 0.6 & 0.8 \\
\hline Italy & 1.3 & 1.1 \\
\hline Netherlands & 1.3 & 1.0 \\
\hline United Kingdom & 1.0 & 0.8 \\
\hline \multicolumn{3}{|c|}{$\begin{array}{l}\text { Labor contribution, population } \\
\text { adjusted } 1 /\end{array}$} \\
\hline France & 0.7 & -0.1 \\
\hline Germany & 0.4 & -0.2 \\
\hline Italy & 0.8 & -0.1 \\
\hline Netherlands & I. 0 & 0.5 \\
\hline United Kingdom & 0.6 & 0.4 \\
\hline \multicolumn{3}{|c|}{$\begin{array}{l}\text { Memorandum items: Working age } \\
\text { population growth }\end{array}$} \\
\hline France & 0.2 & 0.3 \\
\hline Germany & 0.0 & 0.1 \\
\hline Italy & 0.0 & 0.0 \\
\hline Netherlands & 0.4 & 0.4 \\
\hline United Kingdon & 0.4 & 0.4 \\
\hline
\end{tabular}

Sources: OECD Econotric Outlook database; and author's calculations.

I/ Adjustment made by subtracting from the labor contribution working age population growth multiplied by the average labor share in business sector GDP. 
Table 1-5. Germany: Labor Cost Developments

(In percent, unless otherwise noted)

\begin{tabular}{|c|c|c|c|}
\hline & $1992-1996$ & $1997-2001$ & $1992-2001$ \\
\hline \multicolumn{4}{|c|}{ Real compensation rate, hours adjusted } \\
\hline France & 1.9 & 6.2 & 8.1 \\
\hline Germany & 8.9 & 4.8 & 14.1 \\
\hline Italy $1 /$ & 3.7 & -1.0 & 2.7 \\
\hline Netherlands & 6.0 & 6,1 & 12.4 \\
\hline United Kingdom & 6.8 & 12.7 & 20.4 \\
\hline \multicolumn{4}{|c|}{ Share of payroll taxes in wages $2 /$} \\
\hline France & 1.5 & -2.3 & -0.8 \\
\hline Germany & 1.8 & -0.9 & 0.9 \\
\hline Italy $1 /$ & 5.7 & -13.0 & -7.3 \\
\hline Netherlands & 1.6 & 6.7 & 8.3 \\
\hline United Kingdom & .0 .9 & 0.2 & -0.7 \\
\hline \multicolumn{4}{|c|}{ Real effective compensation, hours adjusted } \\
\hline France & -2.8 & -4.0 & -6.6 \\
\hline Germany & 0.2 & -3.2 & -3.0 \\
\hline Italy $2 t$ & -5.8 & -2.4 & -9.1 \\
\hline Netherlands & -4.3 & -0.8 & -5.1 \\
\hline United Kingdom & -6.3 & 4.5 & -2.0 \\
\hline
\end{tabular}

Sources: OECD Economic Outlook database; and author's caiculations.

1/ For 1997-2001, reflects largely substitution of payroll taxes witl a tax on value added (IRAP).

2/ Change in percentage points. 
Table I-6. Net Replacement Rates, 1999

(In percent, after tax and including family and housing benefits)

\begin{tabular}{|c|c|c|c|c|}
\hline & \multicolumn{2}{|c|}{100 percent of ayerage wage } & \multicolumn{2}{|c|}{67 percent of average wage } \\
\hline & Single & $\begin{array}{l}\text { Martied } \\
2 \text { children }\end{array}$ & Single & $\begin{array}{l}\text { Married } \\
2 \text { children }\end{array}$ \\
\hline & \multicolumn{4}{|c|}{ First month of benefit receipt } \\
\hline France & 71 & 74 & 83 & 86 \\
\hline Germany & 60 & 74 & 69 & 74 \\
\hline Italy & 36 & 54 & 36 & 52 \\
\hline Netherlands & 75 & 85 & 92 & 90 \\
\hline \multirow[t]{2}{*}{ United Kingdom } & 50 & 64 & 73 & 83 \\
\hline & \multicolumn{4}{|c|}{ Long-term unemployed } \\
\hline France & 38 & 50 & 55 & 60 \\
\hline Germany & 54 & 52 & 75 & 61 \\
\hline Italy & 28 & 62 & 39 & 75 \\
\hline Netherlands & 60 & 79 & 84 & 94 \\
\hline United Kingdom & 50 & 73 & 73 & 95 \\
\hline
\end{tabular}

Source: OECD (1999). 
Table I-7. Labor Productivity Gaps and Capital Stock Growth, 1992-2001

\begin{tabular}{|c|c|c|c|c|}
\hline & \multicolumn{2}{|c|}{ Productivity, butsiness sector } & & \\
\hline & \multirow[b]{2}{*}{$\begin{array}{c}\text { In percent of Germany } \\
1992\end{array}$} & \multirow{2}{*}{$\begin{array}{c}\text { In percent of } \\
\text { western Germany } \\
1992\end{array}$} & \multicolumn{2}{|c|}{ Per capita capital stock, 1992-2001 } \\
\hline & & & $\begin{array}{l}\text { Predicted growth difference } \\
\text { relative to Germany }\end{array}$ & $\begin{array}{l}\text { Actual growth difference } \\
\text { telative to Germany }\end{array}$ \\
\hline \multicolumn{5}{|c|}{ Labor productivity } \\
\hline France & 116 & 101 & -0.5 & 0.2 \\
\hline Gernuany & 100 & 87 & 0.0 & 0.0 \\
\hline Italy & 111 & 97 & -0.3 & 0.9 \\
\hline Netherlands & 123 & 107 & -0.7 & 0.1 \\
\hline United Kingdom & 91 & 79 & 0.3 & 0.4 \\
\hline
\end{tabular}

Soutce: OECD 2000.

Note: Productivity is GDP per man-hour.

Table I-8. TFP Growth, 1981-2001

\begin{tabular}{|c|c|c|c|c|c|c|}
\hline \multirow[b]{2}{*}{ France } & \multicolumn{3}{|c|}{$\frac{\text { Actual TFP Growth }}{1997-20011992-20011981-91}$} & \multicolumn{3}{|c|}{$\begin{array}{l}\text { HP-filtered TFP Growth } \\
1997-2001 \quad 1992-20011981-91\end{array}$} \\
\hline & 1.2 & 0.9 & 2.0 & 1.0 & 1.0 & 1.9 \\
\hline Germany & 1.0 & 1.1 & 1.8 & 1.3 & 1.4 & 1.6 \\
\hline Italy & 0.2 & 0.8 & 1.4 & 0.7 & 0.9 & 1.6 \\
\hline Netberlands & 0.9 & 1.1 & 2.5 & 1.2 & 1.4 & 2.1 \\
\hline UK & 1.1 & 1.5 & 1.5 & 1.2 & 1.2 & 1.7 \\
\hline \multicolumn{7}{|c|}{ Memorandum item: } \\
\hline US & 1.4 & 1.4 & 1.1 & 1.4 & 1.3 & 1.1 \\
\hline
\end{tabular}

Source: OECD Economic Outlook database and author's calculations. 
Tabie 1-9a. Germany: Regulatory Reform in Product Markets, 1978-1998 V/

(Scale 0-6 from least to most restrictive)

\begin{tabular}{|c|c|c|c|c|c|c|c|}
\hline & \multirow[t]{2}{*}{1978} & \multirow[t]{2}{*}{1982} & \multirow[t]{2}{*}{1988} & \multirow[t]{2}{*}{1993} & \multirow[t]{2}{*}{1998} & $1988-98$ & $1978-98$ \\
\hline & & & & & & \multicolumn{2}{|c|}{ Percent change } \\
\hline France & 6.0 & 5.9 & 5.7 & 4.7 & 3.9 & -31.6 & -35.0 \\
\hline Germany & 5.2 & 5.2 & 4.7 & 3.8 & 2.4 & -48.9 & -53.8 \\
\hline Italy & 5.8 & 5.8 & 5.8 & 5.3 & 4.3 & -25.9 & -25.9 \\
\hline Netherlands & 5.3 & 5.5 & 5.5 & 4.1 & 3.0 & -45.5 & -43.4 \\
\hline United Kingdom & 4.3 & 4.2 & 3.5 & 1.9 & 1.0 & -71.4 & -76.7 \\
\hline United States & 4.0 & 3.3 & 2.5 & 2.0 & 1.4 & -44.0 & -65.0 \\
\hline
\end{tabular}

Source: Nicoletti et al. (2001).

1/ Simple average of indicators for 7 industries: gas, electricity, post, telecoms air transport, railways, freight.

2/ In percest.

Table I-9b. Germany: Detailed Indicators of Product Market Regulation, 1998 1/ (Scale 0-6 from least to most restrictive)

\begin{tabular}{lcccccc}
\hline & France & Germany & Italy & Netherlands & $\begin{array}{c}\text { United } \\
\text { Kingdom }\end{array}$ & $\begin{array}{c}\text { Memorandum } \\
\text { item: } \\
\text { United States }\end{array}$ \\
\hline Overali & 2.1 & 1.4 & 2.3 & 1.4 & 0.5 & 1.0 \\
State control & 2.6 & 1.8 & 3.9 & 2.3 & 0.6 & 0.9 \\
Barriers to entrepreneurship & 2.7 & 2.1 & 2.7 & 1.4 & 0.5 & 1.3 \\
Barriers to trade and investment & 1.0 & 0.5 & 0.5 & 0.5 & 0.4 & 0.9 \\
Economic regulation & 2.3 & 1.4 & 3.5 & 2.1 & 0.6 & 1.0 \\
Administrative regulation & 3.1 & 2.7 & 3.0 & 1.5 & 0.5 & 1.2 \\
\hline
\end{tabular}

Source: Nicoletti et al. (2000).

I/ Scetors covered include retail distribution, road freight, air passenger and railway transport, and telecommunications. 
Table I-10. Germany: R\&D Expenditure, 1980-2000 // (Averages, in percent of GDP)

\begin{tabular}{|c|c|c|c|c|}
\hline & \multicolumn{2}{|c|}{$1980 \mathrm{~s}$} & \multicolumn{2}{|c|}{$1990 \mathrm{~s}$} \\
\hline & Business & Total & Business & Total \\
\hline France & 1.26 & 2.15 & 1.42 & 2.30 \\
\hline Germany & 1.92 & 2.70 & 1.63 & 2.38 \\
\hline Italy & 0.61 & 1.07 & 0.59 & 1.09 \\
\hline Netherlands & 1.12 & 1,98 & 1.04 & 1.98 \\
\hline United Kingdom & 1.48 & 2.23 & 1.30 & 1.96 \\
\hline \multicolumn{5}{|c|}{ Memorandum item: } \\
\hline United States & 1.88 & 2,59 & 1.86 & 2.57 \\
\hline
\end{tabular}

Source: OECD Science and Technology database.

1/ Comparsions across time are affected by data breaks.

Table I-11. Germany: Employment Protection Legislation (Scaie 0-6 from least to most restrictive)

\begin{tabular}{lcccc}
\hline & \multicolumn{2}{c}{ Late 1980s } & \multicolumn{2}{c}{ Late 1990s } \\
\cline { 2 - 5 } & $\begin{array}{l}\text { Regular } \\
\text { employment }\end{array}$ & Overall & $\begin{array}{c}\text { Regular } \\
\text { employment }\end{array}$ & Overall \\
\hline France & 2.3 & 2.7 & 2.3 & 3.0 \\
Germany & 2.7 & 3.2 & 2.8 & 2.5 \\
Italy & 2.8 & 4.1 & 2.8 & 3.3 \\
Netherlands & 3.1 & 2.7 & 3.1 & 2.1 \\
United Kingdom & 0.8 & 0.5 & 0.8 & 0.5 \\
Memoorandum item: & & & & 0.2 \\
United States & 0.2 & 0.2 & 0.2 & \\
\hline
\end{tabular}

Source: OECD, Labor Market Indicators database. 
Table I-12. Germany; Education, 1970-98

(Average number of years of education in working-age population)

\begin{tabular}{lrrrrr}
\hline & 1970 & 1980 & 1990 & 1998 & $\begin{array}{c}\text { Change } \\
1990-981 /\end{array}$ \\
\hline France & 8.8 & 9.5 & 10.0 & 10.6 & 6.4 \\
Germany & 9.5 & 11.4 & 12.9 & 13.6 & 5.1 \\
Italy & 6.6 & 7.3 & 8.4 & 9.8 & 17.1 \\
Netherlands & 9.0 & 10.1 & 11.2 & 11.9 & 5.7 \\
United Kingdom & 9.1 & 10.1 & 10.9 & 12.0 & 9.7 \\
Memorandum item: & & & & & \\
United States & 11.6 & 12.2 & 12.6 & 12.7 & 1.0 \\
\hline
\end{tabular}

Source: Bassanini et al. $(2001)$.

1/ In percent.

Table I-13. Germany: Ranking Educational Achievement Based on 2000 PISA Study

(Highest and lowest possible rank among 32 industrial and developing counfries)

\begin{tabular}{lccc}
\hline & Reading & Mathematics & Science \\
\hline France & $11 / 16$ & $10 / 15$ & $13 / 18$ \\
Germany & $21 / 25$ & $20 / 22$ & $19 / 23$ \\
Italy & $19 / 24$ & $26 / 28$ & $22 / 25$ \\
Netherlands & $\mathrm{NA}$ & $\mathrm{NA}$ & $\mathrm{NA}$ \\
United Kingdom & $5 / 9$ & $6 / 10$ & $3 / 7$ \\
Memorandum item: & & & $11 / 21$ \\
United States & $10 / 20$ & $16 / 23$ & \\
\hline
\end{tabular}

Source: $O E C D(2002 a)$. 
Table I-14. The Role of the Public Sector, 1992-2001

(Geometric average in percent, unless otherwise indicated)

\begin{tabular}{lcc}
\hline & $1997-2001$ & $1992-2001$ \\
\hline Per eapita real GDP growth $1 /$ & & \\
France & 2.6 & 1.7 \\
Germany & 1.8 & 1.3 \\
Italy & 2.1 & 1.6 \\
Netherlands & 2.9 & 2.3 \\
United Kingdom & 2.3 & 2.3 \\
Per capita real GDP growth, & & \\
business sector 1/ & & \\
France & 2.8 & 1.8 \\
Germany & 2.1 & 1.7 \\
Italy & 2.3 & 1.8 \\
Netherlands & 3.0 & 2.5 \\
United Kingdom & 2.5 & 2.7 \\
Government employment & & \\
France & & \\
Germany & 0.8 & 0.9 \\
Italy & -1.7 & -1.7 \\
Netherlands & -0.5 & -0.5 \\
United Kingdom & 1.3 & 0.4 \\
Government employment $2 /$ & 1991 & -1.4 \\
France & 5.3 & 2001 \\
Germany & 5.2 & 4.3 \\
Italy & 3.6 & 3.4 \\
Netherlands & 0.0 & 0.7 \\
United Kingdom & 5.1 \\
\hline & & \\
\hline
\end{tabular}

Sources: OECD Economic Outlook database; and IMF WEO database.

1/ Based on working age population.

2/ Employment level, in millions. 
Table I-15. Explatining the Per Capita Real GDP Growth Differences, 1992-2001 (In percent)

\begin{tabular}{|c|c|c|c|c|c|c|c|c|}
\hline & \multicolumn{2}{|c|}{ France } & \multicolumn{2}{|c|}{ Italy } & \multicolumn{2}{|c|}{ Netherlands } & \multicolumn{2}{|c|}{ United Kingdom } \\
\hline & $1997-2001$ & $1992-2001$ & $1997-2001$ & $\{992-200\}$ & $1997-2001$ & $1992-2001$ & $1997-2001$ & $1992-2001$ \\
\hline \multicolumn{9}{|l|}{ Real GDP per capita } \\
\hline \multicolumn{9}{|l|}{ German growth rate less } \\
\hline country growth rate & -0.8 & -0.3 & -0.3 & -0.2 & -1.1 & -1.0 & -0.5 & -0.9 \\
\hline \multicolumn{9}{|l|}{ Additional German growth with } \\
\hline Same fiscal impuise & 0.1 & 0.4 & 0.1 & -0.2 & 0.3 & 0.3 & -0.8 & 0.1 \\
\hline Same interest rate & -0.1 & 0.0 & 0.2 & 0.0 & 0.1 & 0.1 & 0.0 & 0.0 \\
\hline Sum & 0.1 & 0.4 & 0.3 & -0.2 & 0.3 & 0.4 & -0.8 & 0.1 \\
\hline \multicolumn{9}{|l|}{ Remaining growth gap } \\
\hline With same fiseal & -0.7 & 0.0 & -0.2 & -0.4 & -0.8 & -0.7 & -1.3 & -0.9 \\
\hline With same fistalintertest rate & -0.7 & 0.0 & 0.0 & -0.4 & -0.7 & -0.6 & -1.3 & -0.9 \\
\hline \multicolumn{9}{|l|}{ Private Consumption per capita } \\
\hline \multicolumn{9}{|l|}{ German growth rate less } \\
\hline country growth rate & -0.5 & 0.0 & -0.9 & -0.1 & -1.3 & -0.9 & .7 .8 & -1.5 \\
\hline \multicolumn{9}{|l|}{ Additional growth: } \\
\hline Same fiscal impulse & 0.2 & 0.7 & 0.2 & -0.4 & 0.5 & 0.6 & -1.5 & 0.1 \\
\hline Same interest rate & -0.1 & 0.0 & 0.2 & 0.0 & 0.1 & 0.1 & 0.0 & 0.0 \\
\hline Sum & 0.2 & 0.7 & 0.4 & -0.4 & 0.6 & 0.7 & -1.5 & 0.1 \\
\hline \multicolumn{9}{|l|}{ Renaaituing growth gap } \\
\hline With same fiscal & -0.3 & 0.8 & -0.7 & -0.5 & -0.8 & -0.4 & -3.3 & -1.4 \\
\hline With same fiscalfinterest rate & -0.3 & 0.8 & -0.5 & 0.5 & -0.7 & -0.3 & -3.4 & -1.4 \\
\hline
\end{tabular}

Sources: OECD Analytical Database; WEO; and author's simulations with OEF model. 
Table I-16. The Size of Industry, Energy and the Construction Sectors (In percent of total value added)

\begin{tabular}{lccccc}
\hline & \multicolumn{2}{c}{ Industry and energy } & & \multicolumn{2}{c}{ Construction } \\
\cline { 2 - 3 } \cline { 6 - 6 } & 1991 & 2001 & & 1991 & 2001 \\
\hline France & 20.8 & 21.7 & & 6.0 & 4.2 \\
Germany & 28.6 & 23.8 & & 6.5 & 5.0 \\
Italy & 24.4 & 23.8 & & 5.9 & 5.0 \\
Netherlands & 22.5 & 20.8 & & 9.2 & 8.7 \\
United Kingdom & 25.9 & 22.4 & & 5.5 & 4.7 \\
\hline
\end{tabular}

Sources: Eurostat; and author's calculations.

Table I-17, Value Added Excluding Construction, Industry, and Energy (Average annual percent change)

\begin{tabular}{lcccc}
\hline & & \multicolumn{2}{c}{ Value added excluding: } & \\
\cline { 3 - 3 } & & Construction & Industry, energy & Value added \\
\hline \multirow{2}{*}{ France } & $1992-2001$ & 1.9 & 1.6 & 1.8 \\
Germany & $1997-2001$ & 2.8 & 2.4 & 2.6 \\
& $1992-2001$ & 1.9 & 2.4 & 1.8 \\
Italy & $1997-2001$ & 2.5 & 2.4 & 2.2 \\
\multirow{2}{*}{ Netherlands } & $1992-2001$ & 1.7 & 1.7 & 1.7 \\
\multirow{3}{*}{ United Kingdom } & $1997-2001$ & 2.1 & 2.1 & 2.0 \\
& $1992-2000$ & 2.9 & 3.0 & 2.8 \\
& $1997-2000$ & 3.8 & 4.3 & 3.7 \\
& $1992-2001$ & 2.8 & 3.2 & 2.8 \\
& $1997-2001$ & 3.0 & 3.8 & 3.0 \\
\hline
\end{tabular}

Sources: Eurostat; and author's calculations. 
Table I-18 . Job Growth in Manufacturing (In percent per andum)

\begin{tabular}{lcc}
\hline & $1992-2001$ & $1997-2001$ \\
\hline France & -1.2 & -0.2 \\
Germany & -2.8 & -0.5 \\
Italy & -0.8 & 0.1 \\
Netheriands & -0.8 & 0.7 \\
United Kingdom & -1.8 & -2.0 \\
\hline
\end{tabular}

Sources: OECD; and author's calculations.

Table 1-19. Turbulence: Standard Deviation of Sectoral Growth Rates (Average over 1992-2001, in percent)

\begin{tabular}{lcc}
\hline & Valte adided & Employment \\
\hline France & 2.5 & 2.1 \\
Germany & 2.8 & 3.8 \\
Italy & 1.9 & 2.4 \\
Netherlands & 2.4 & 2.4 \\
United Kingdom & 2.4 & 3.1 \\
\hline
\end{tabular}

Sources: OECD; Eurostat; and author's calculations. 
Table I-20. Germany: Public Sector Balances (In percent of GDP)

\begin{tabular}{|c|c|c|c|c|c|}
\hline & \multicolumn{2}{|c|}{ General Government Balance } & \multirow[b]{2}{*}{$\begin{array}{l}\text { Trewhand } \\
\text { (3) }\end{array}$} & \multirow{2}{*}{$\begin{array}{c}\text { Public } \\
\text { enterprises } \\
\text { (4) }\end{array}$} & \multirow[b]{2}{*}{$\begin{array}{c}\text { Total } \\
(1)+(3)+(4)\end{array}$} \\
\hline & $\begin{array}{c}\text { Total } 1 / \\
\text { (1) }\end{array}$ & $\begin{array}{c}\text { Primary } 1 / \\
\text { (2) }\end{array}$ & & & \\
\hline 1990 & -2.0 & 0.1 & -0.2 & -0.4 & -2.6 \\
\hline 1991 & -3.0 & -0.6 & -0.7 & -0.5 & -4.2 \\
\hline 1992 & -2.5 & 0.2 & -0.9 & -0.8 & -4.3 \\
\hline 1993 & -3.1 & -0.3 & -1.2 & -0.6 & 4.9 \\
\hline 1994 & -2.4 & 0.5 & -1.0 & -0.6 & -4.0 \\
\hline 1995 & -3.3 & -0.1 & $\ldots$ & $\ldots$ & -3.3 \\
\hline 1996 & $-3,4$ & -0.2 & $\ldots$ & $\ldots$ & -3.4 \\
\hline 1997 & -2.7 & 0.5 & $\ldots$ & $\ldots$ & -2.7 \\
\hline 1998 & -2.2 & 1.1 & $\ldots$ & $\ldots$ & -2.2 \\
\hline 1999 & -1.5 & 1.6 & $\ldots$ & $\ldots$ & -1.5 \\
\hline 2000 & 1.1 & 4.1 & & $\ldots$ & 1.1 \\
\hline 2001 & -2.8 & 0.1 & $\ldots$ & $\ldots$ & $-2,8$ \\
\hline
\end{tabular}

Souree: OECD Economic Surveys, Gernany 1995, Table 6, p. 26.

Note: Treuhand Anstalt: Operations wound up in at end 1994; successor organization financed directly from government budget. Post and Telecoms were incorporated in 1995 while railways now receive subsidies directly both from state and federal governments; the debt of the railways was taken over by the government at end 1994. Excludes East Gemaan housing debt taken over by goveminent in 1995 .

1/ For 2000 , includes receipts from the sale of UMTS licenses equivalent to roughly 2.5 percent of GDP. These receipts are excluded from calculations of the structural balance.

Table I-21. Primary Structural Fiscal Balancess, 1991 2001 (In percent of potential GDP)

\begin{tabular}{lccccc}
\hline & France & Germany 1/ & Italy & Netherlands & $\begin{array}{c}\text { United } \\
\text { Kingdom }\end{array}$ \\
\hline 1991 & -0.3 & -3.8 & -0.8 & 1.2 & -1.3 \\
1992 & -1.1 & -3.2 & 1.6 & 0.8 & -3.9 \\
1993 & -0.7 & -2.1 & 3.4 & 2.6 & -4.4 \\
1994 & -0.7 & -1.3 & 2.8 & 1.6 & -3.5 \\
1995 & -0.7 & -0.2 & 4.0 & 1.5 & -2.0 \\
1996 & 1.3 & 0.4 & 4.8 & 3.8 & -0.7 \\
1997 & 2.0 & 1.5 & 7.0 & 3.1 & 1.7 \\
1998 & 1.4 & 1.8 & 5.6 & 2.8 & 2.9 \\
1999 & 1.8 & 2.2 & 5.5 & 2.9 & 3.4 \\
2000 & 1.0 & 1.5 & 4.9 & 3.2 & 3.4 \\
2001 & 1.0 & 0.6 & 4.3 & 2.3 & 1.5 \\
\hline
\end{tabular}

Soutees: WEO databaste; and author's calculations.

$1 /$ Inctuding the spending by public enterprises and the Treuhand Anstalt shown in Table 16. 
Figure I-1. A Factor Decomposition of Business Sector Real GDP Growth, 1980-2001
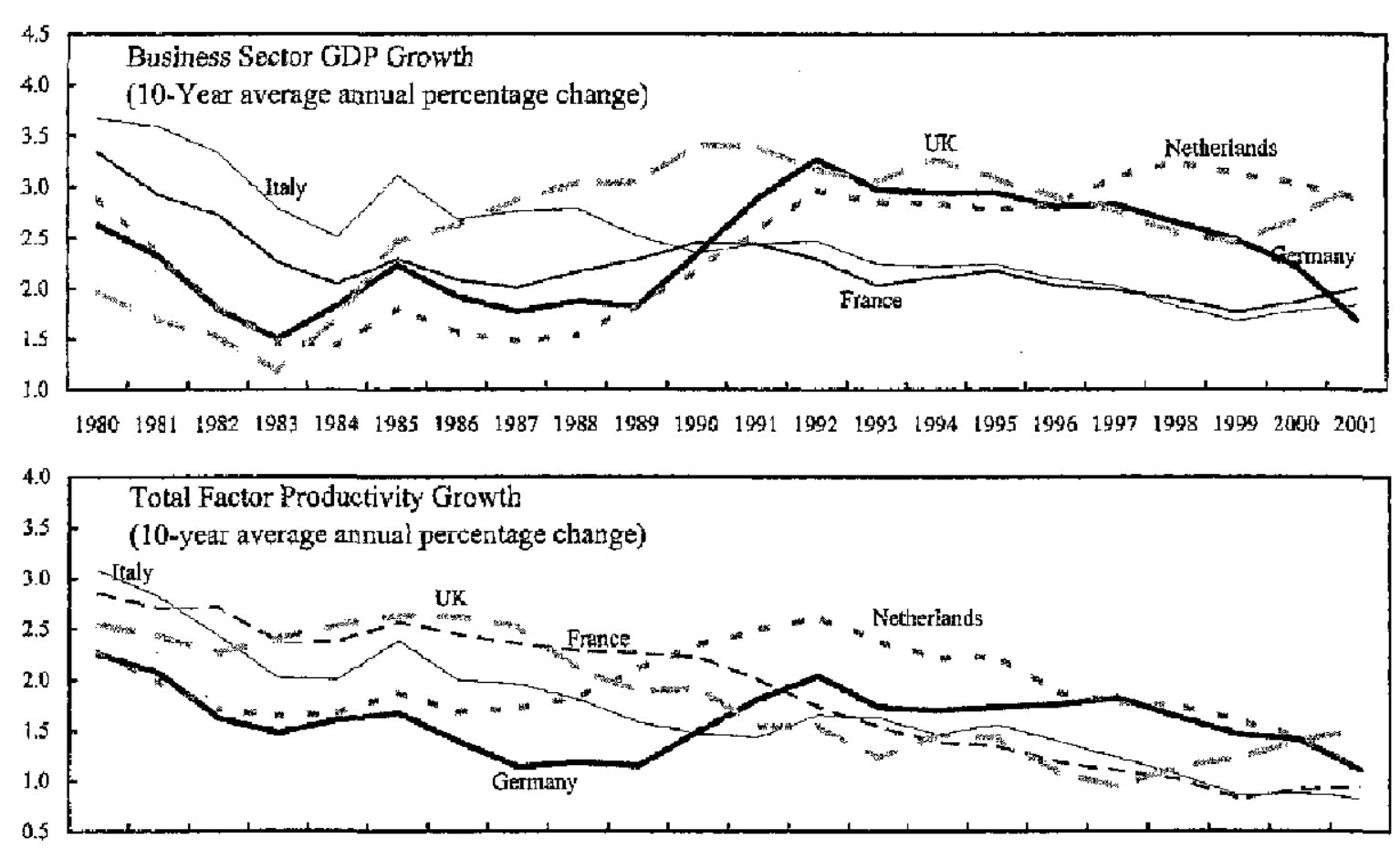

$\begin{array}{llllllllllllllllllllll}1980 & 1981 & 1982 & 1983 & 1984 & 1985 & 1986 & 1987 & 1988 & 1989 & 1990 & 1991 & 1592 & 1993 & 1994 & 1995 & 1996 & 1997 & 1998 & 1999 & 2000 & 2001\end{array}$
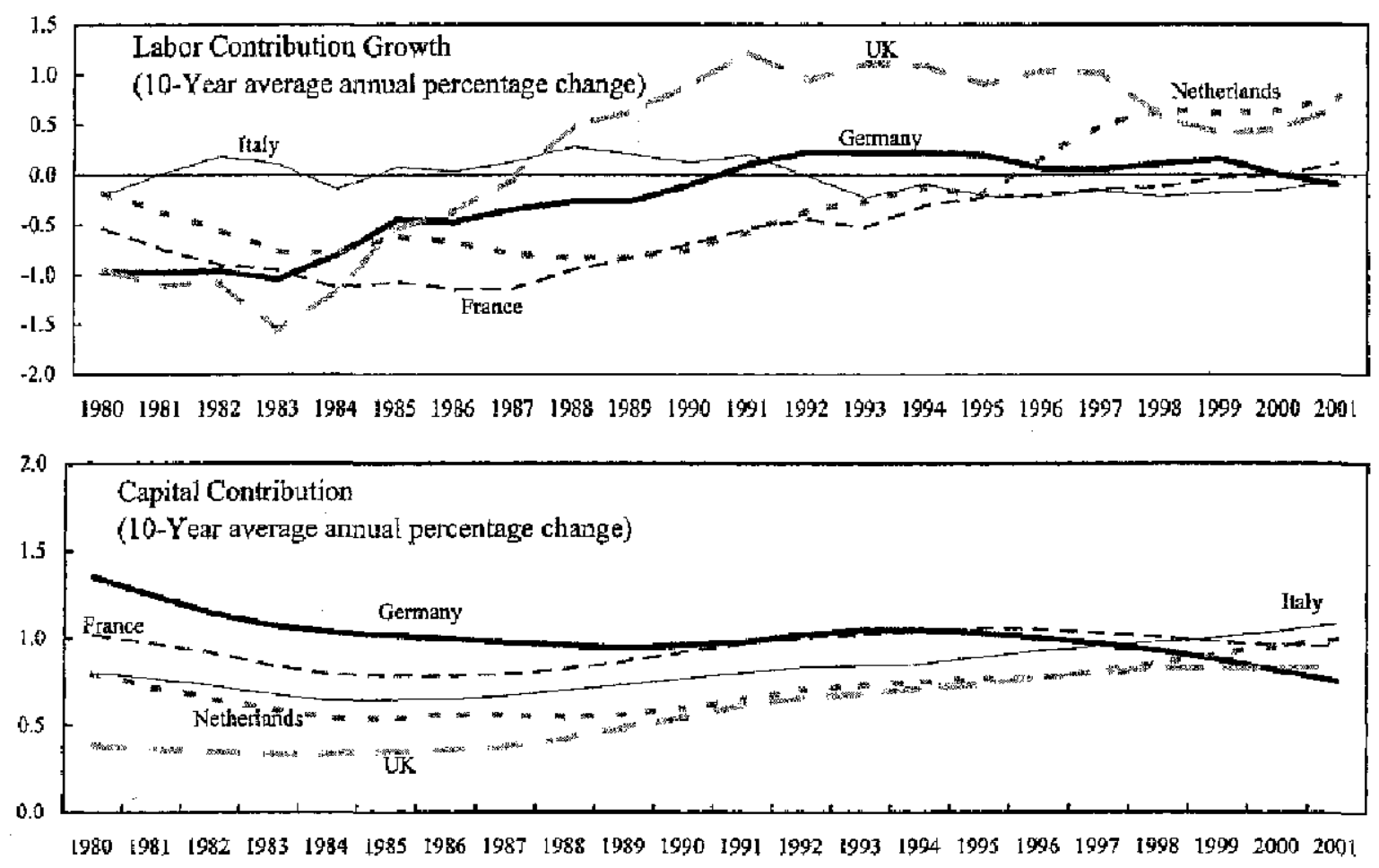

Soutces: OECD Economic Outlook database; and author's calculations. 
Figure I-2. Labor Supply and Factor Proportions, 1980-2001
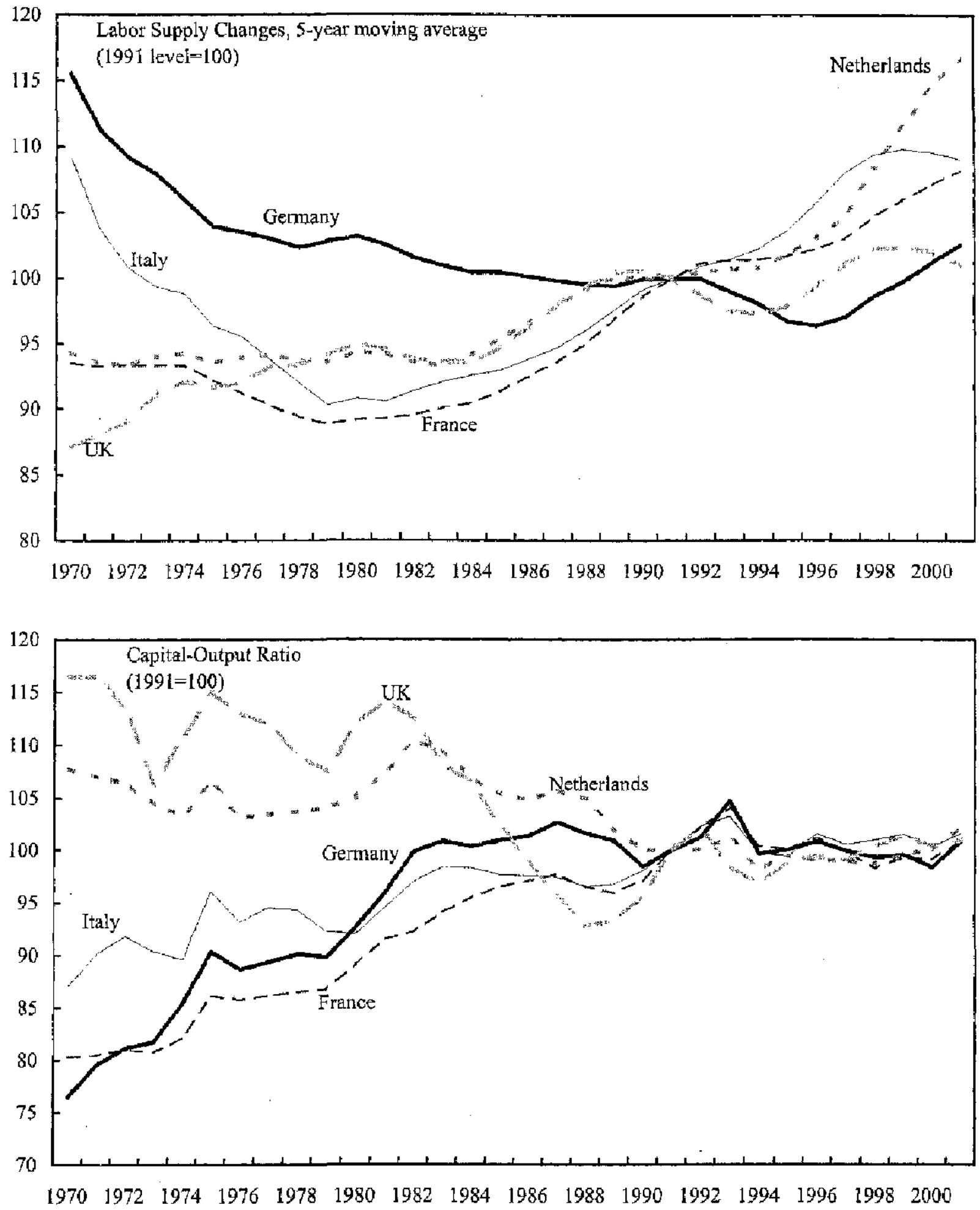

Sources: OECD Economic Outlook database; and authort's calculations. 
Figure I-3. Unemployment and Gross Replacement Rates, 1971-2001
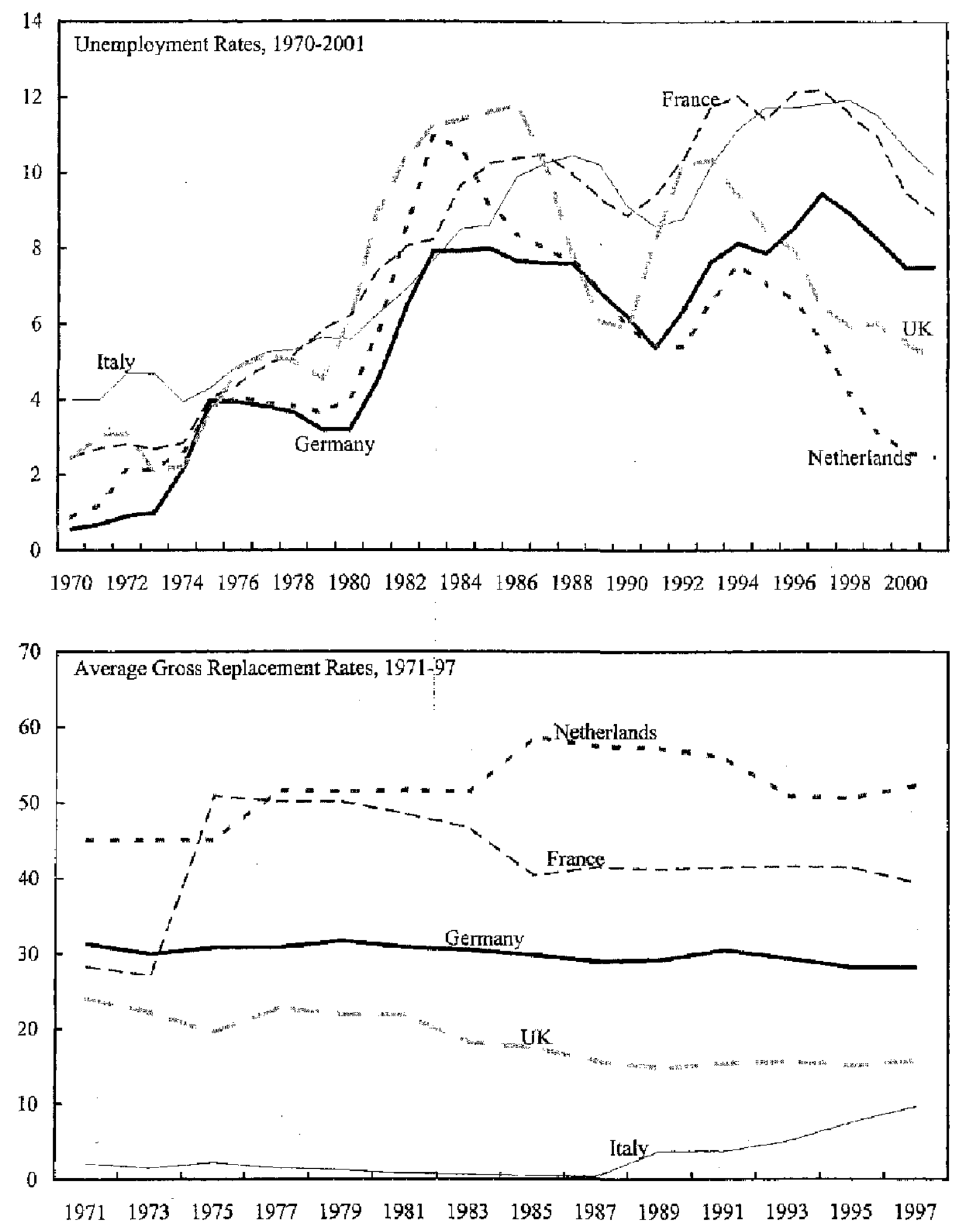

Sources: OECD Economic Outlook database; and OECD Benefit and Work Incentives database. 1i Replacement rates are an average for various individuals in various earning categories. For Italy, the replacement rate includes only unemployment insurance. 
Figure I-4. Taxes and Contributions, 1980-2001
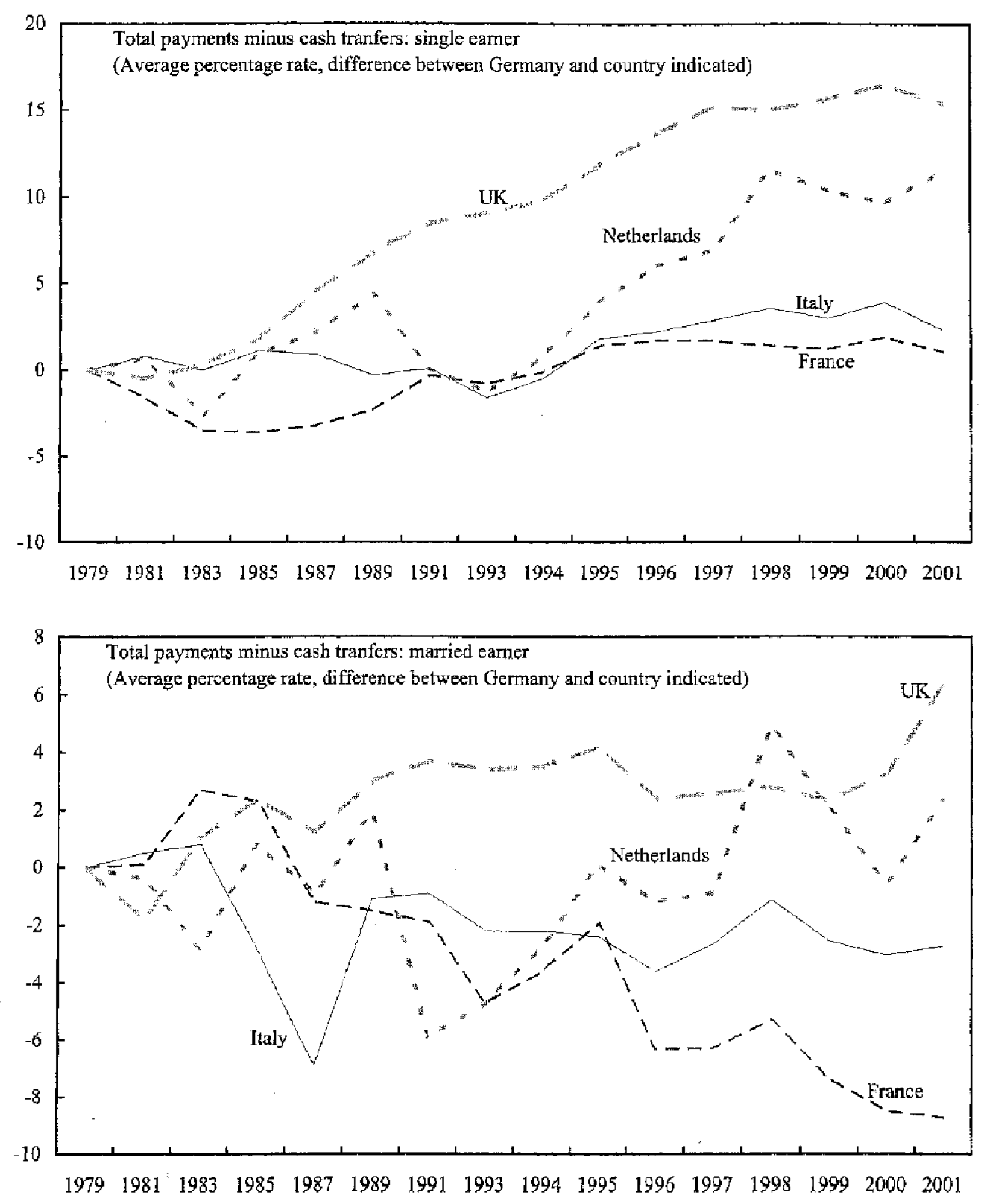

Source: OECD Tax and Benefits database. 
Figure I-5. Labor Demand and Payroll Taxes, 1970-2001
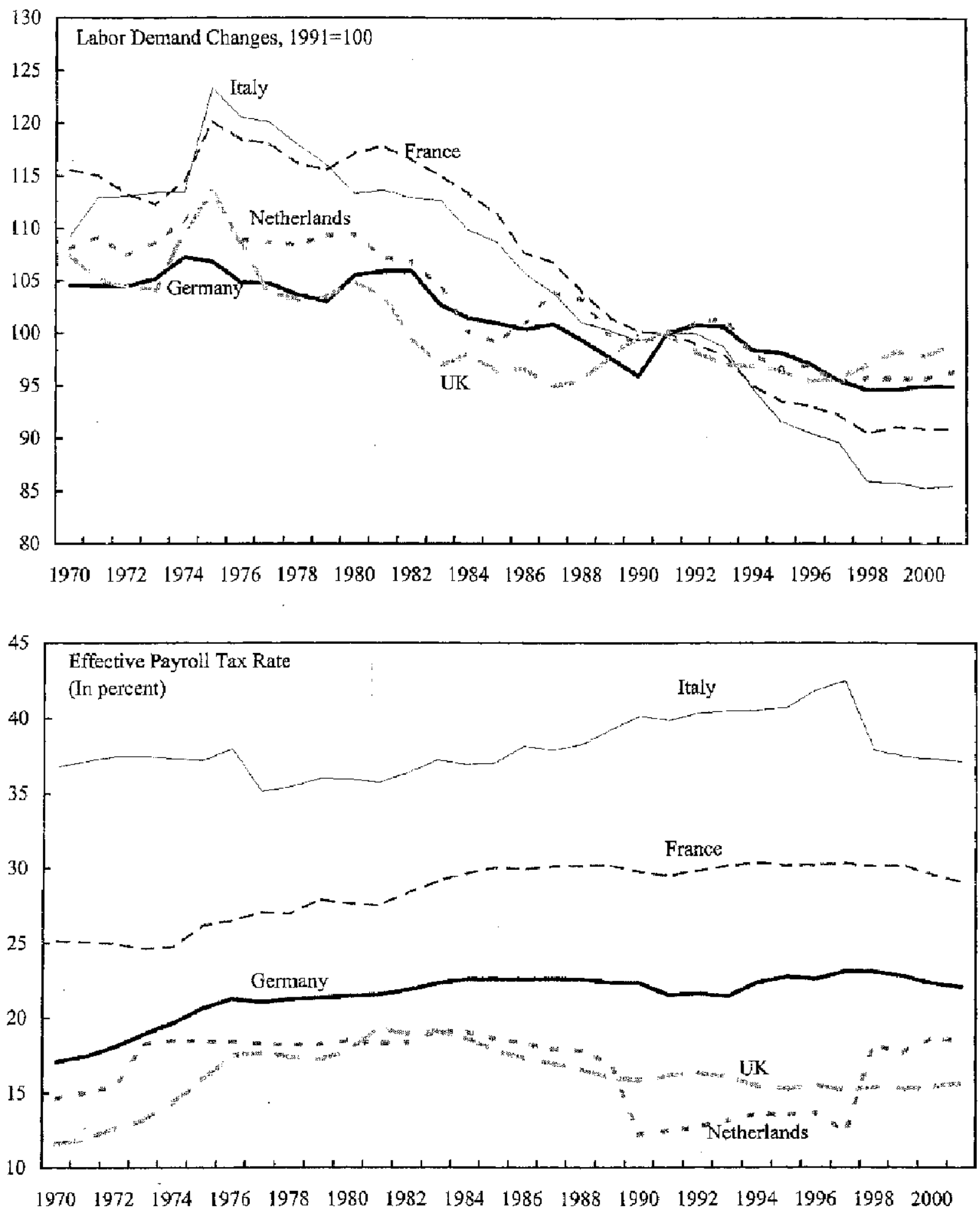

Sources: OECD Economic Outlook database; and author's calculations. 
Figure I-6. Fiscal Policy and Monetary Conditions, 1991-2001
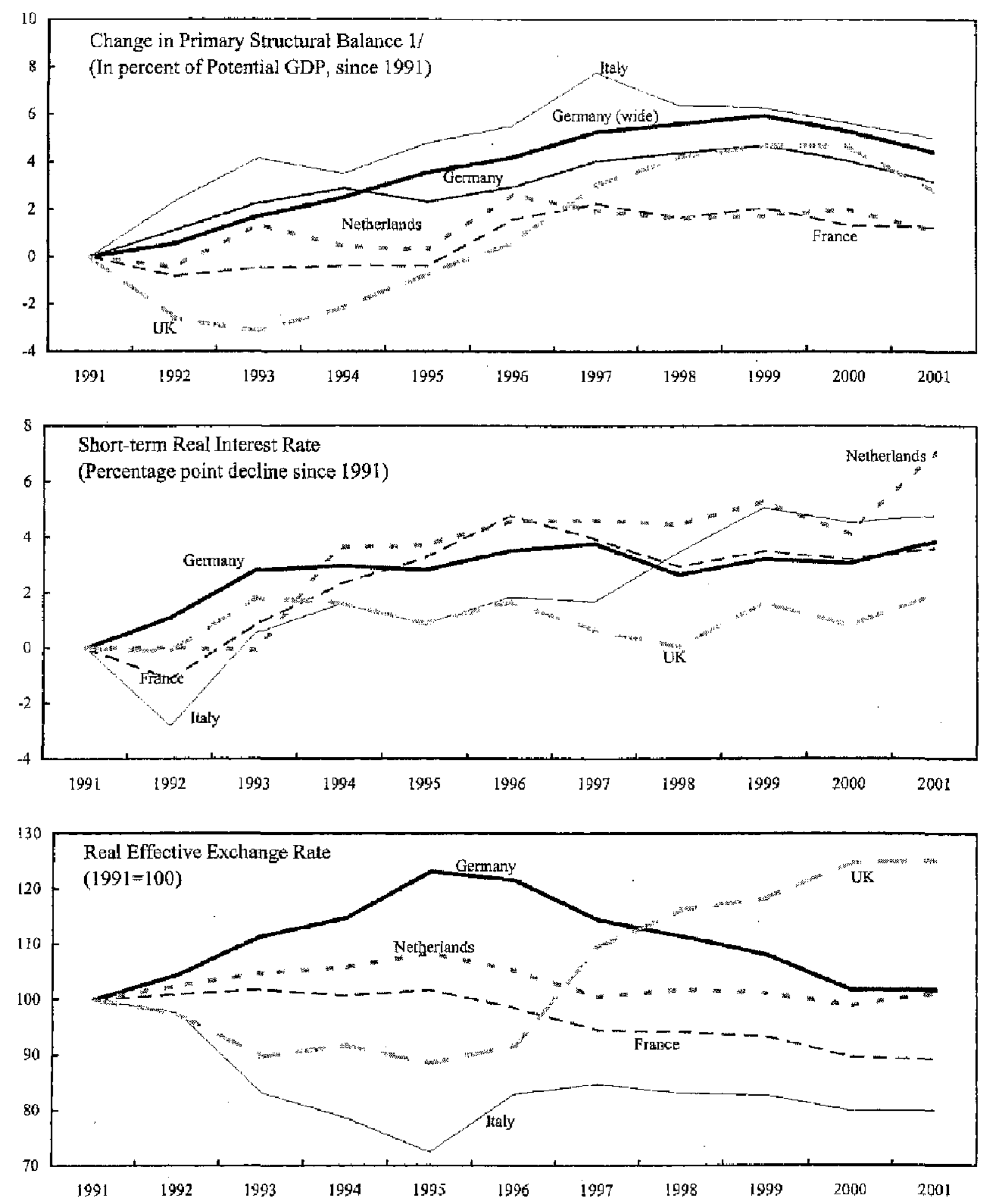

Sources: IMF, World Economic Outlook; OECD Economic Survey for Germany (1996); and author's calculations.

1/ The "wide" prinary structural balance for Germany includes the unification-related deficits of the major public enterprises and the Treuhand Anstalt. 
Figure 1-7. Government Revenue and Primary Expenditure, 1991-2001
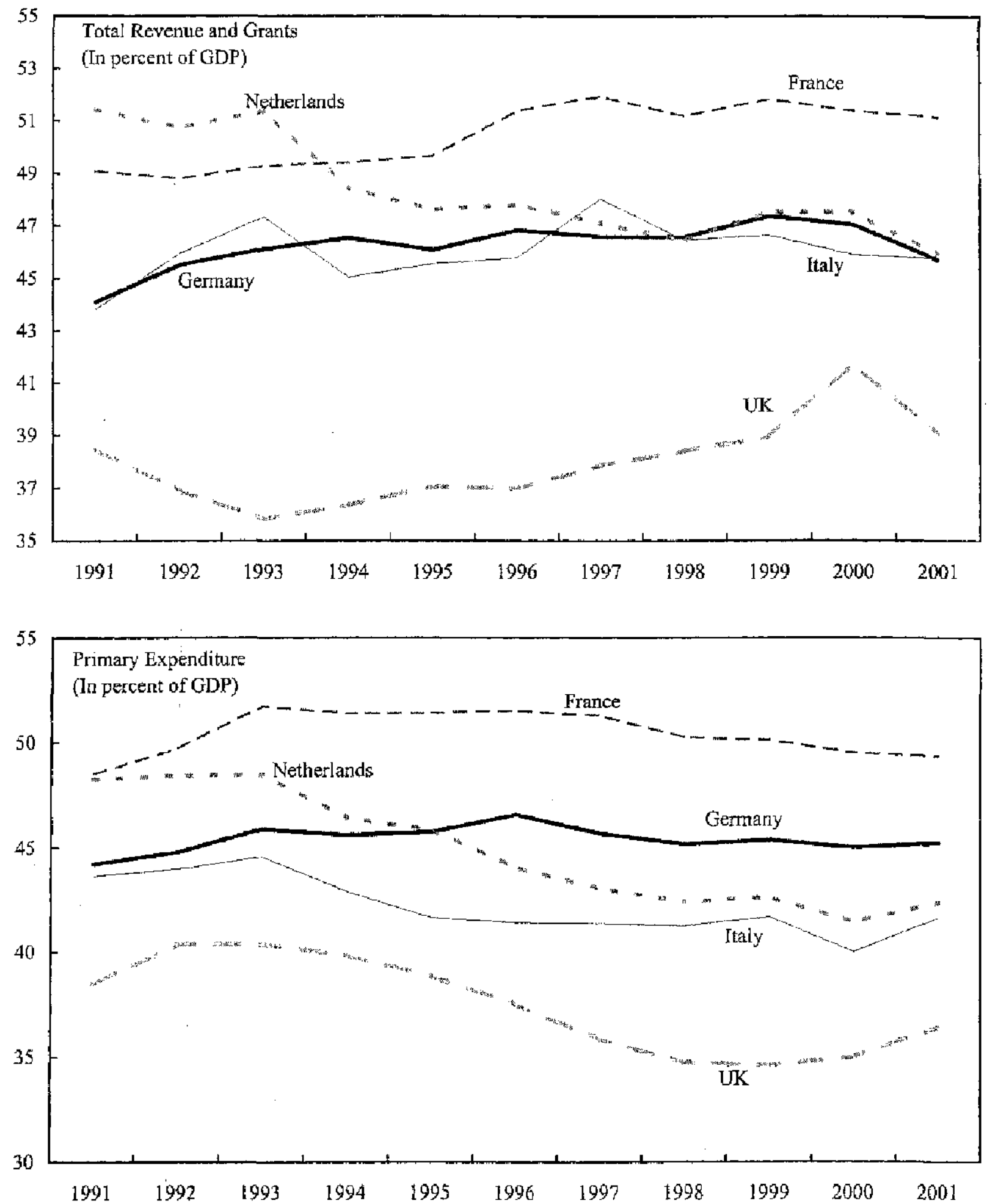

Source: IMF, World Economic Outlook. 
Figure I-8. Value Added in Industry and Energy and the Real Exchange Rate, 1980-2001
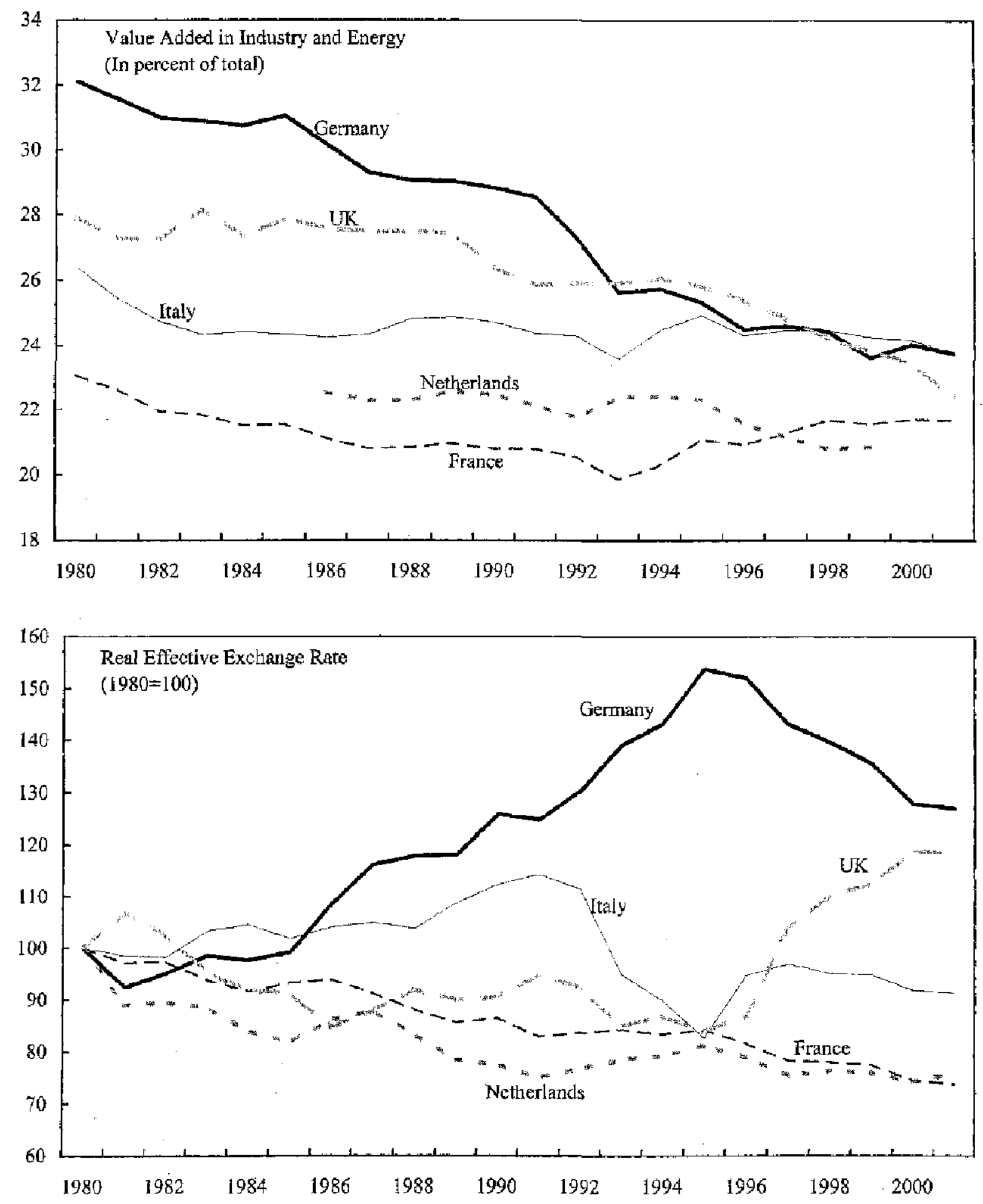

Sources: Eurostat; and IFS database. 
Figure I-9. Eastern Germany: Economic Convergence Compared, 1991-2001
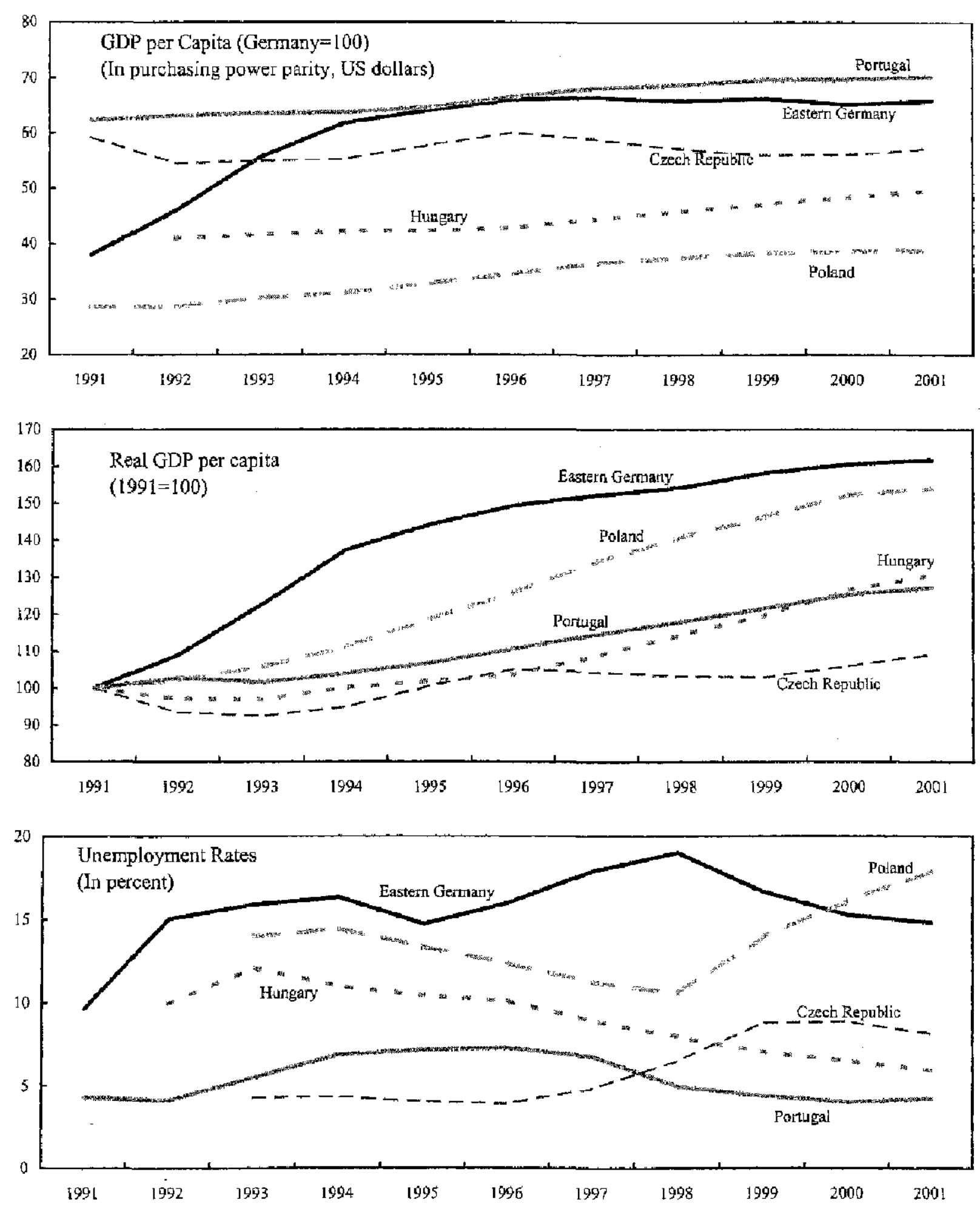

Sources: OECD Economic Outlook database, Volkswitschaftliche Gesantrechinungen (for East Germany), and staff calculations. 
Figure I-10. Germany: East-West Convergence, 1991-2001
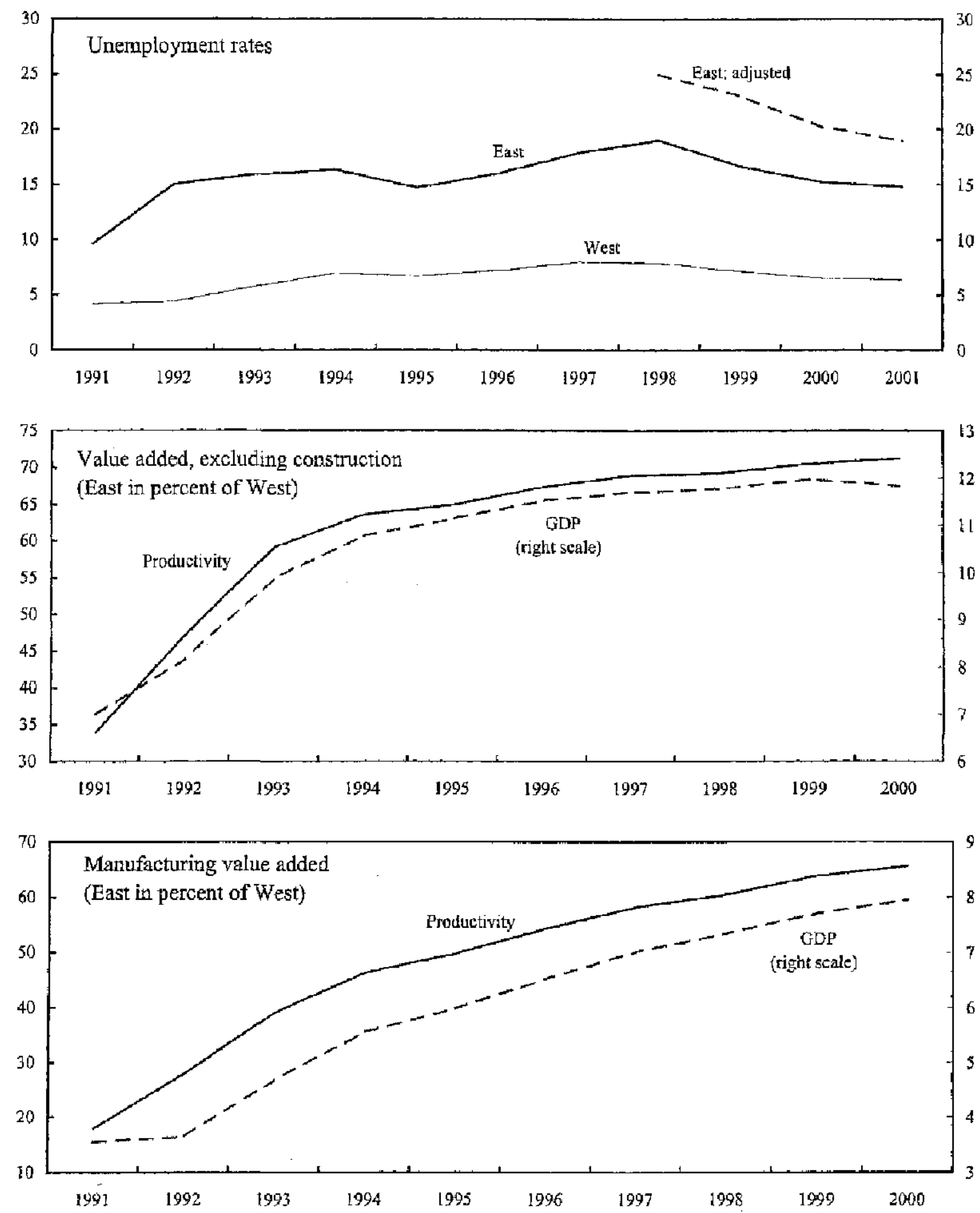

Sources: Volkswirtschaftliche Gesantrechnungen; Eurostat; and author's calculations. 
Figure 1-11. Germany: East-West Unemployment and Labor Costs, 1991-2001

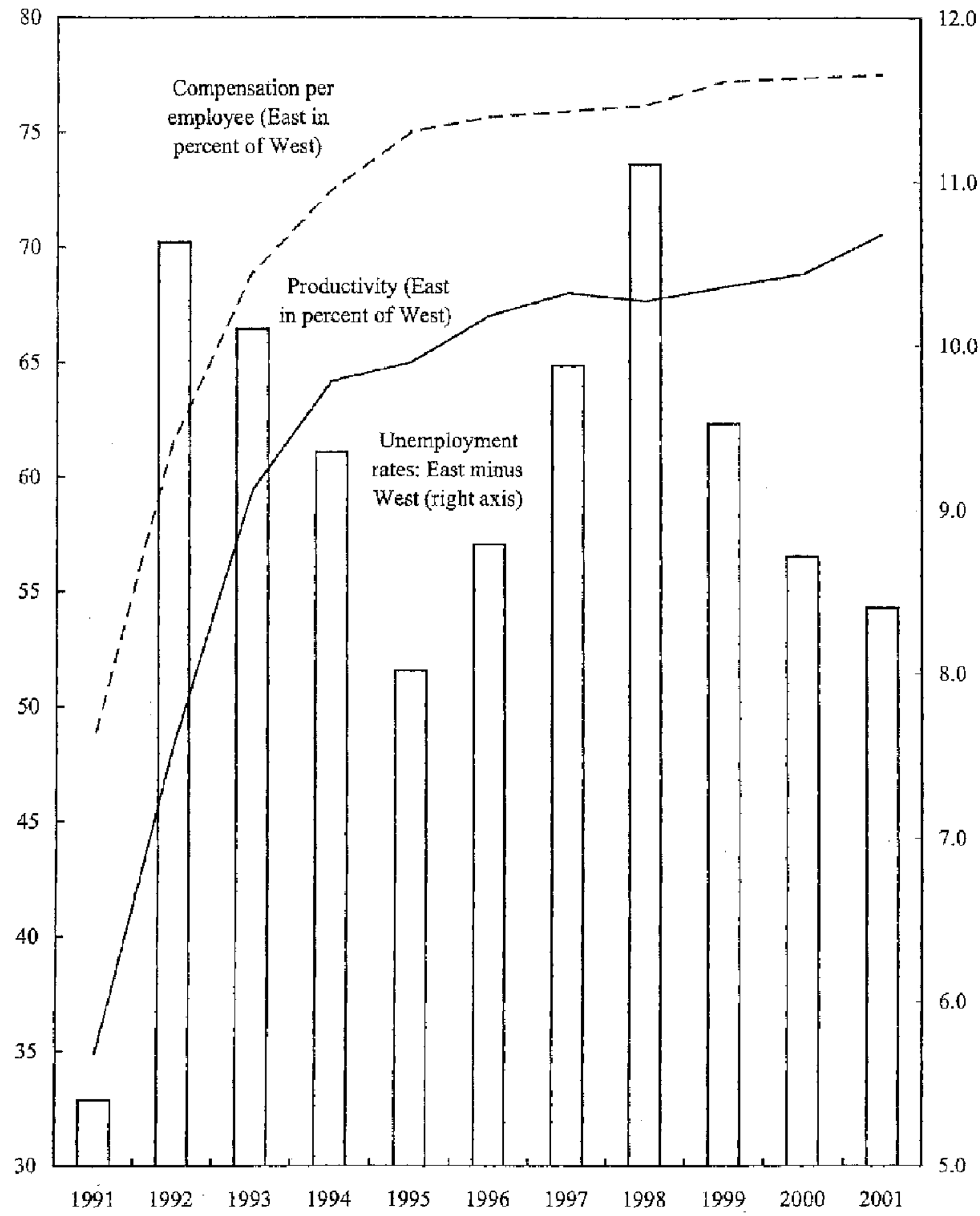

Source: Volkswirtschafthiche Gesamrechnungen; Eurostat; and author's calculations. 
Figure 1-12. Real GDP Growth and Asset Prices
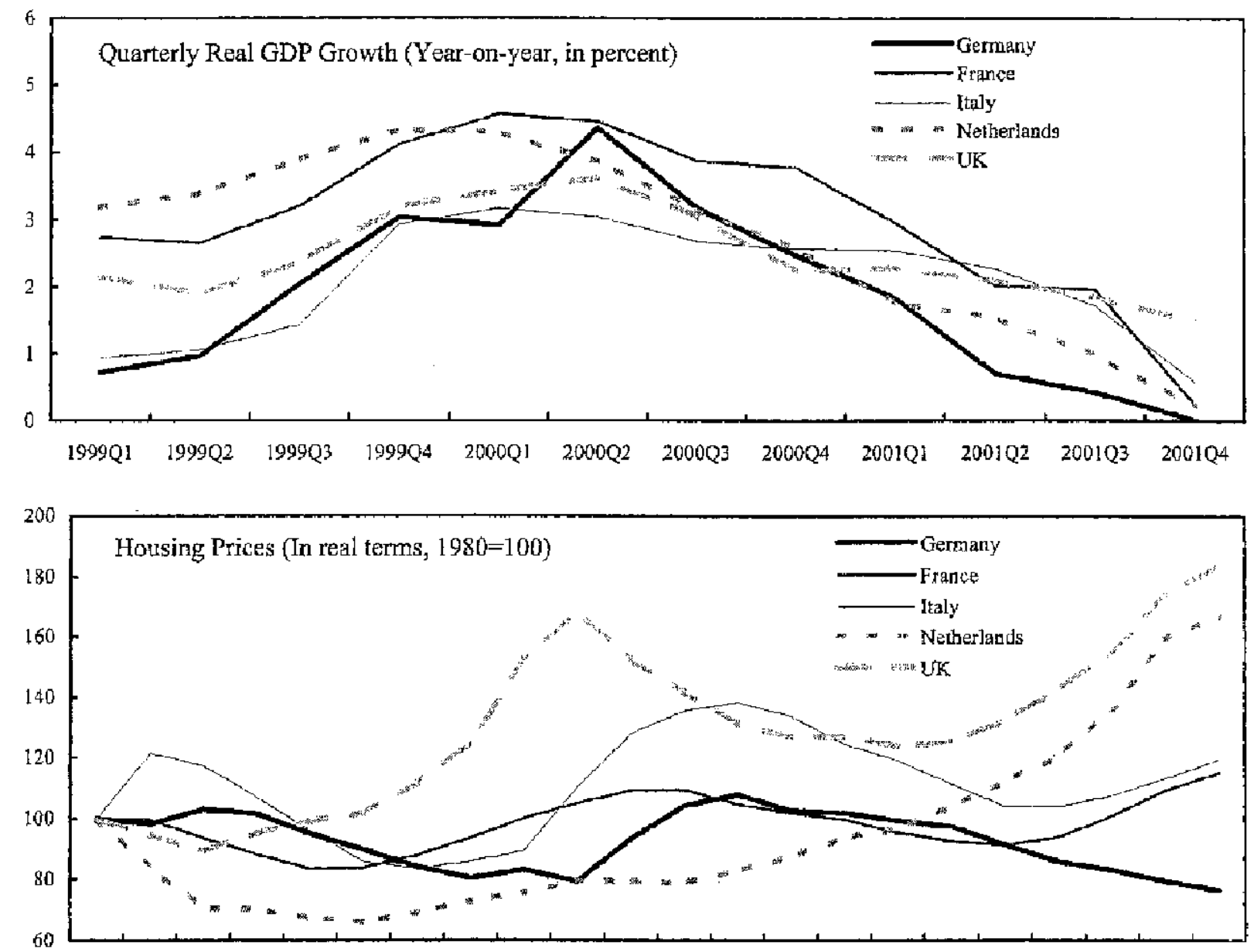

$1980 \quad 198119821983198419851986198719881989199019911992199319941995199619971998199920002001$

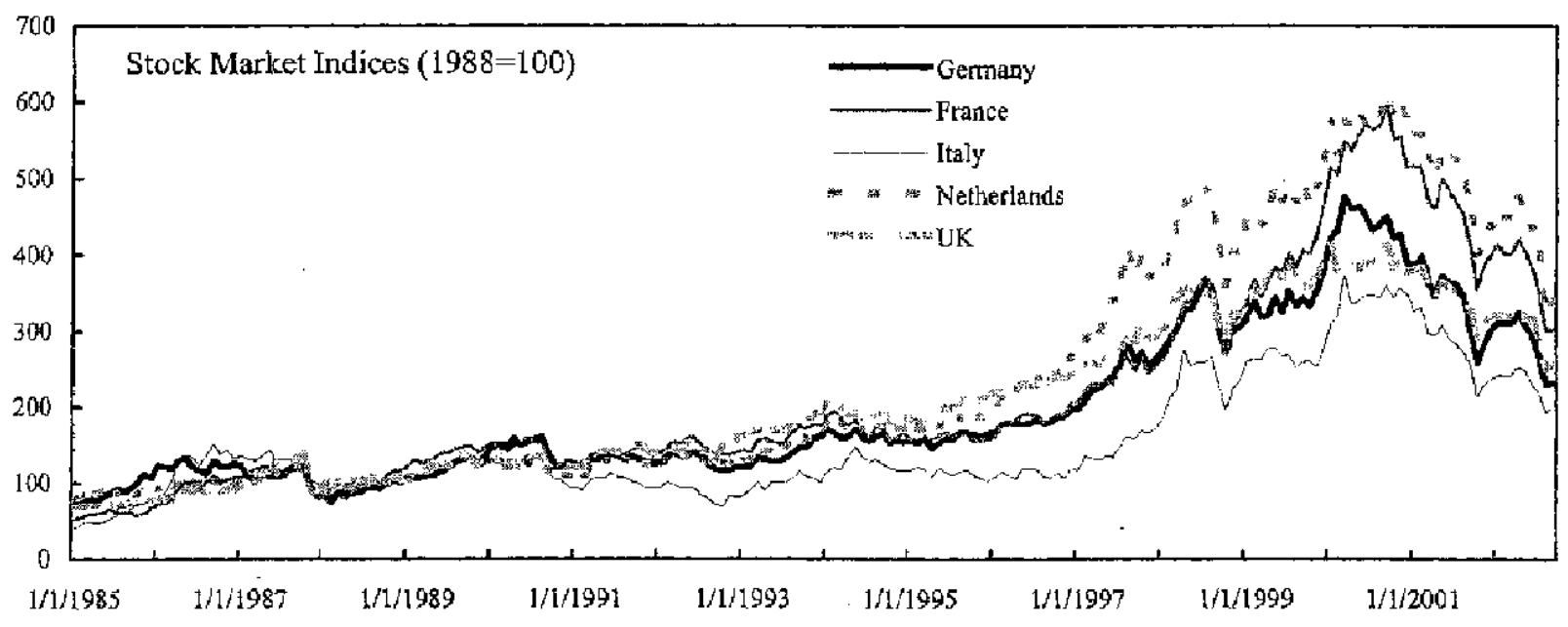

Sources: WEO database; BIS; and Bloomberg. 
Figure I-13a. Real GDP Growth Rate in Selected Countries:

Response to Innovation in US Real GDP Growth Rate, 1992:1-2001:4 1/
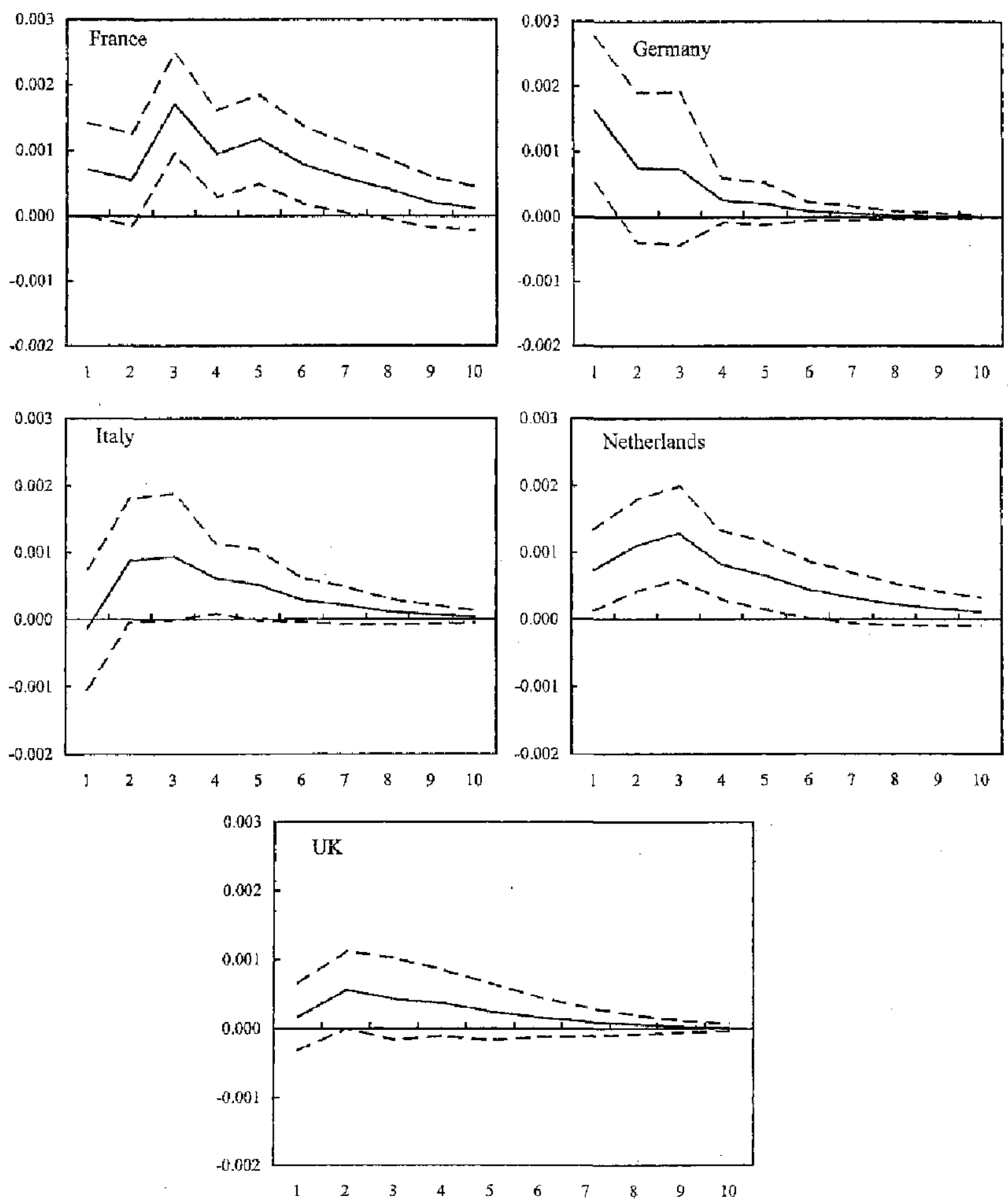

Source: IMF, World Economic Outlook and staff calculations.

1/ Obtained from running bivariate VARs. Size of innovation is one standard error. Error bands are two standard errors wide. 
Figure I-13b. Real GDP Deviation from HP-Filtered Real GDP in Selected Countries:

Response to Innovation in Deviation of US Real GDP from US HP-Filtered Real GDP, 1992:1-2001:4 1/
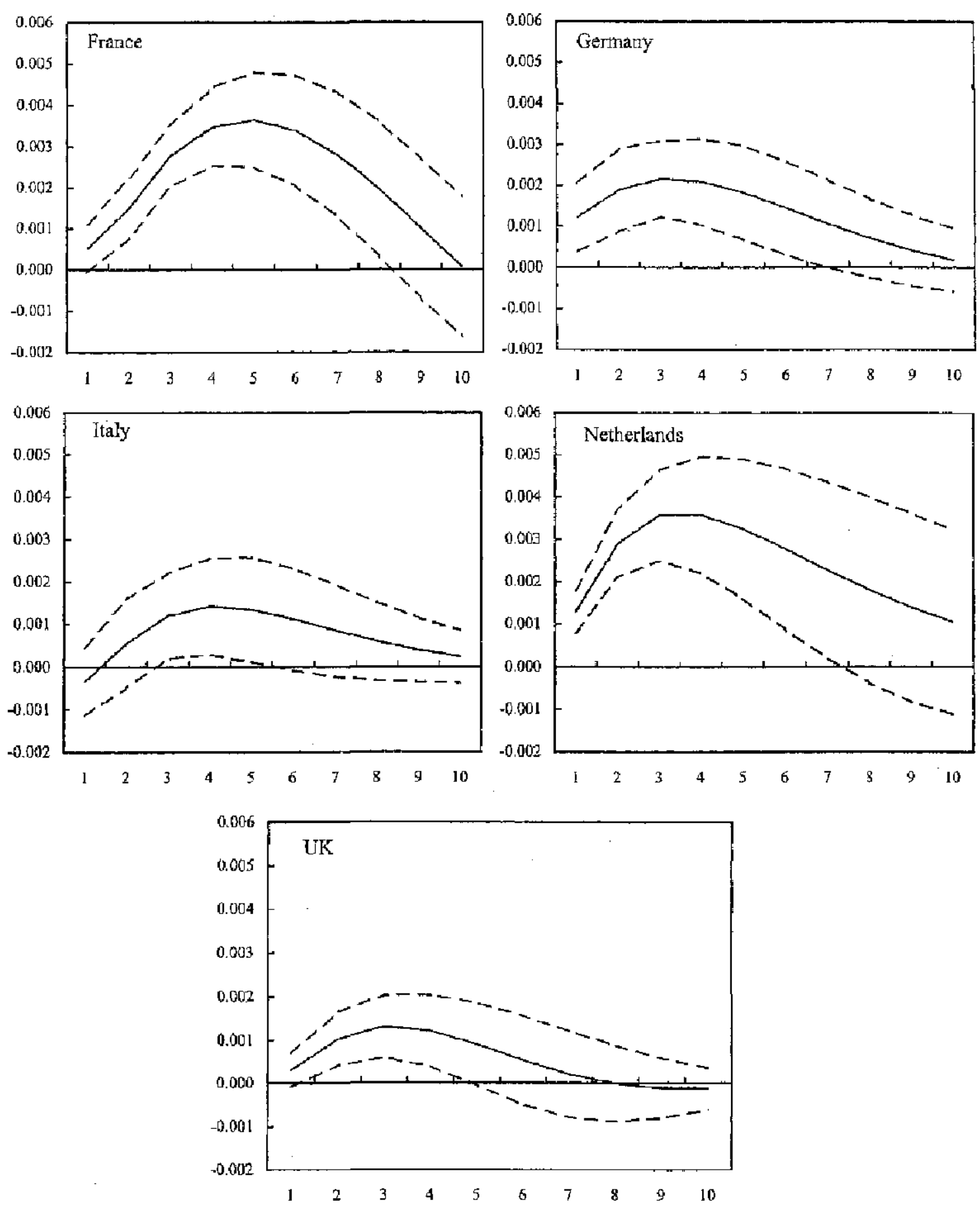

Source: IMF, World Economic Outlook and staff calculations.

l/ Obtained from running bivariate VARs. Size of inrovation is one stancard error. Error bands ate two standard errors wide. 


\section{Is Germany Competitive? ? $^{43}$}

65. Despite a large positive contribution to growth from the external sector in the latest downswing, questions remain as to whether Germany has fully recovered from the loss of competitiveness that followed unification. This chapter attempts to provide some perspective on the current status of competitiveness. Because the debate is sometimes cast as "did Germany enter EMU at the wrong exchange rate," the paper distinguishes between Germany's competitiveness within and outside the euro area. In addition to analyzing trends in measures of the real exchange rate and profitability, the chaptet assesses competitiveness from the perspective of the equilibrium external current account balance and looks at recent trends in Germany's export market shares.

66. Most of the present concerns about German competitiveness are linked to the sharp appreciation of the real exchange rate following unification. However, two points need to be stressed. First, the appreciation was not an unusual event from an historical perspective and moreover, at least on a multilateral basis, it was reversed in the second half of the 1990s. And second, large real exchange rate swings are part of the resource allocation. process following an economic shock and do not necessarily indicate disequilibrium. In particular, the macroeconomic policies associated with unification helped to fuel a surge in domestic demand that was in part satisfied by imports and financed by foreign savings. Exchange rate appreciation facilitated this process. Nonetheless, some key questions for competitiveness are whether the exchange rate overshot and whether moves toward more fixed nominal exchange rates within Europe (and eventual monetary union in 1999) bindered the subsequent unwinding of the high real exchange rate. To the extent that adjustment of the real exchange rate had to come about more through wage and productivity adjustments, as opposed to nominal depreciation, Germany could have found itself uncompetitive within Europe for an extended period, with potential implications for economic performance.

\section{The following main conclusions emerge:}

- On a multilateral basis, Germany appears to be comfortably competitive. The real effective exchange rate is below historical trend values and at a level consistent with medium-term macroeconomic balance. Competitiveness derives to a large extent from a relatively favorable value of the euro against other major currencies and is thus a euro-area characteristic.

- Germany's competitiveness against euro area partners is less clear, but most indicators are within bounds of normal variation. Competitiveness has improved since the mid-1990s and, in more recent years, earlier losses of Germany's euro area export market share have started to be reversed.

${ }^{43}$ Prepared by Laura Kodres. 


\section{A. Real Exchange Rate Trends and Profitability}

68. From a longer-term perspective, the real effective appreciation of the deutsche mark after 1990 was large, but was not unprecedented. Using CPI-based indices, the deutsche mark exhibits several lengthy cycles from the late 1960s onward (Figure II-1). ${ }^{44}$ The post-unification appreciation was larger than run ups in the real exchange rate in the $1980 \mathrm{~s}$, but much smaller than the appreciation in the first half of the 1970s. After changing direction in 1995, the real exchange rate had fallen back to below pre-unification levels by the late $1990 \mathrm{~s}$. A similar story is told by data on relative unit labor costs (ULCs) in the business sector-although on this basis, the real appreciation of the early 1990 s was larger than the rise in relative CPIs. Its subsequent decline was also larger.

Figure II-1. Germany: Real Effective Exchange Rates Against 19 Industrial Countries, 1960-2002

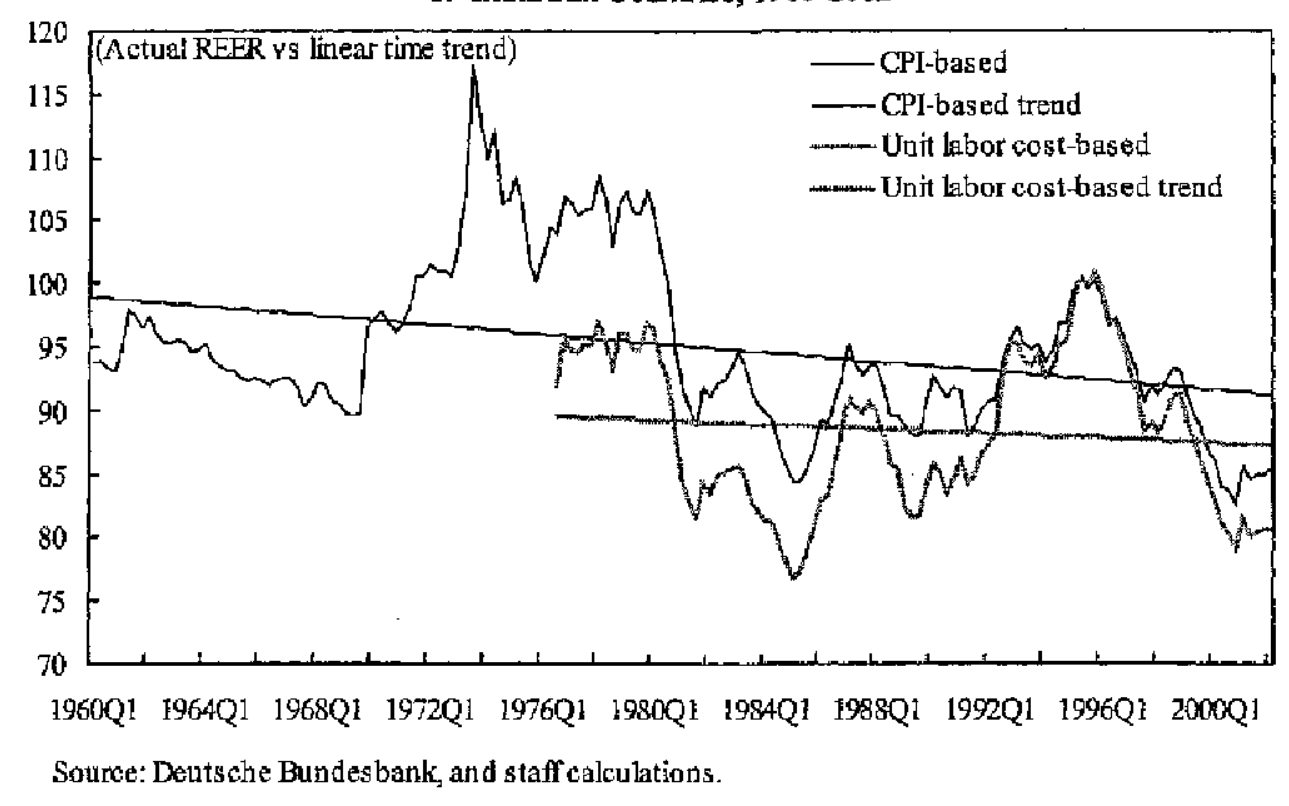

69. The shlfts in the real effective exchange rate (REER) in the 1990s reflected reinforcing movements in nominal exchange rates and wage costs. The run up in the exchange rate was a combination of a nominal effective appreciation of the deutsche mark and rapid wage growth, both due to wage convergence in eastern Germany and-preceding unification somewhat-wage inflation in western Germany (Figure II-2). The shift of course in the ULC-based REER was prompted by nominal effective depreciation of the deutsche mark-and later the euro-as well as moderating ULC inflation relative to that of trade partners. Lower ULC inflation in Germany mainly reflected falling employment and a corresponding surge of productivity in manufacturing.

\footnotetext{
${ }^{44}$ Data in Figure II- 1 are calculated from CPIs and ULCs from 18 partner countries by the Bundesbank. IMF estimates based on more countries show a similar pattern.
} 
70. By the late 1990s, measures of the real effective exchange rate were also below their long-term trend values. Such trends provide only a rudimentary benchmark and are hostage to choice of start and end periods.

Nonetheless, the deviations from trend in early 2002 were significant: about 6 percent for CPI-based measures and 7 percent for ULC-based measures. REER measures suffer from various limitations. However, more broadly defined measures based on price or cost deflators of total sales are also more than 6 percent below their long-term averages. ${ }^{45}$

71. A sirnilar pattern is observed in movements in Germany's real effective exchange rate agalnst its euro area partners in the 1990 s (Figure II- 3 ). ${ }^{46}$ There was a

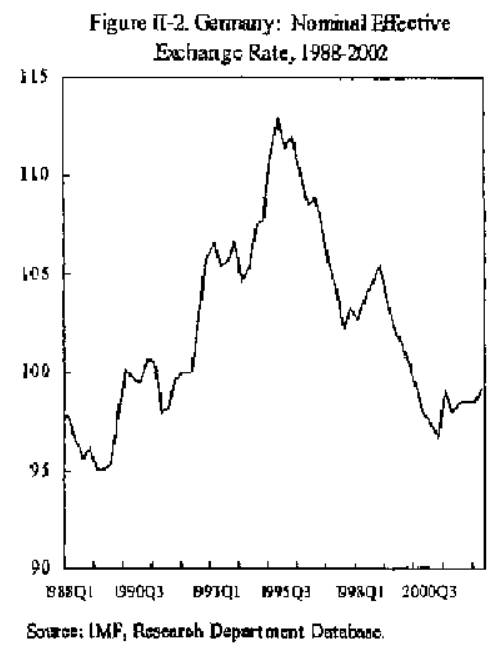
large loss of competitiveness in first half of 1990 s followed by some recovery in the second half. The real effective appreciation in the first half of the 1990 s against the euro area partly reflected revaluations within ERM and the deutsche mark's anchor role in the system. The devaluations of the lira, and, to a lesser extent, the peseta and escudo, during the 1992 and 1994 ERM crises led to a sharp nominal appreciation of the deutsche mark, which peaked in mid-1995. Bilateral exchange rates within the ERM stabilized around end-1996 and were fixed when monetary union came into effect in 1999. Those that devalued within the ERM generally had higher inflation than Germany in the late 1990 s permitting a steady erosion of their initial competitiveness gain. Germany's real exchange rate against euro area partners measured in CPI-terms thus peaked in 1995 and subsequently depreciated at a modest pace. By the beginning of 2002, it was still somewhat appreciated relative to its 1990 level.

72. Based on relative ULCs, competitiveness against euro area partners has been improving more rapidly since the mid-1990s, although from a more appreciated position (Figure II-4). The appreciation in the early 1990s was more pronounced than for the CPI-based measures because of Germany's lack of wage moderation compared to that in key partners. ${ }^{47}$ Since the mid-1990s, Germany's ULC inflation in the business sector-and, more narrowly, in manufacturing-has been significantly lower than elsewhere in the euro area. However, by early 2001 , the real exchange rate was still about 10 percent higher than it was in $1990 .^{48}$

${ }^{45}$ See Deutsche Bundesbank, Monthly Report, August 2002, p. 43.

${ }^{46}$ The euro area partners consist of Austria, Belgitum, Finland, France, Greece, Ireland, Italy, the Netherlands, Portugal, and Spain. Data are from the Bundesbank and composite indices are based on trade weights.

${ }^{47}$ See Chapter I for more details.

${ }^{48}$ Deutsche Bundesbank (1998) notes that the cress-country comparability of manufacturingbased ULC measures is not ideal. In particular, they do not take into account the fact that the 
Figure II-3a. Germany: Nominal Effective Exchange Rate and Selected Bilateral Rates Against Euro Area, $1988-2002$

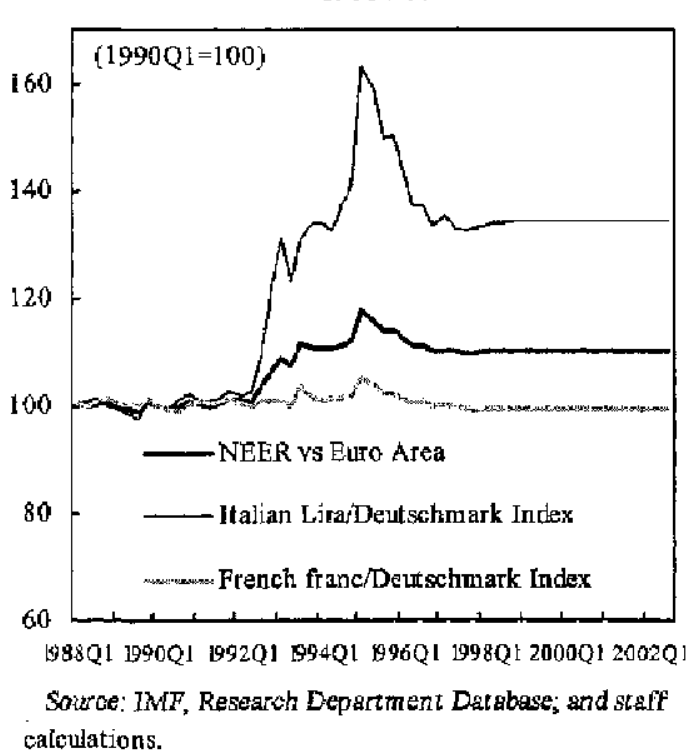

Figure 11-4a. Gemany: Real Effective Exchange Rate Based on Unit Labor Cost in Manufacturing, 1988-2002

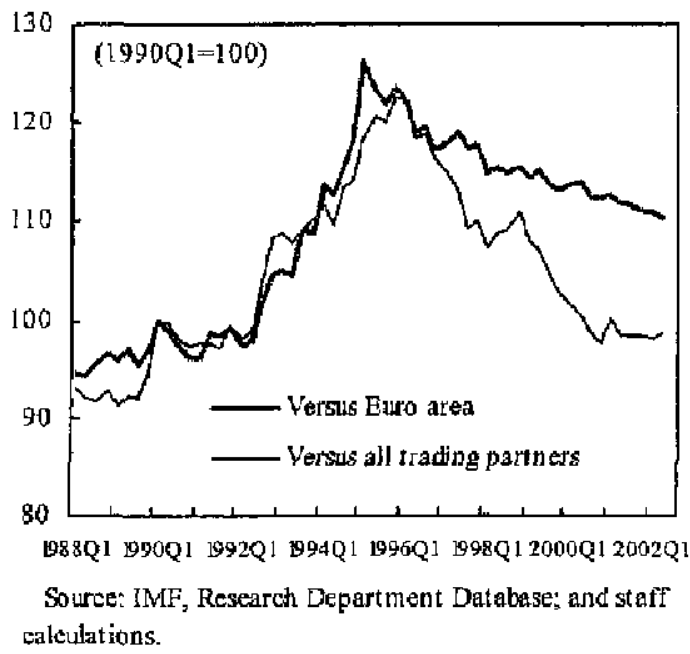

Figure II-3b. Germany: Real Effective Exchange Rate CPI-Based Against Euro Area, 1988-2002

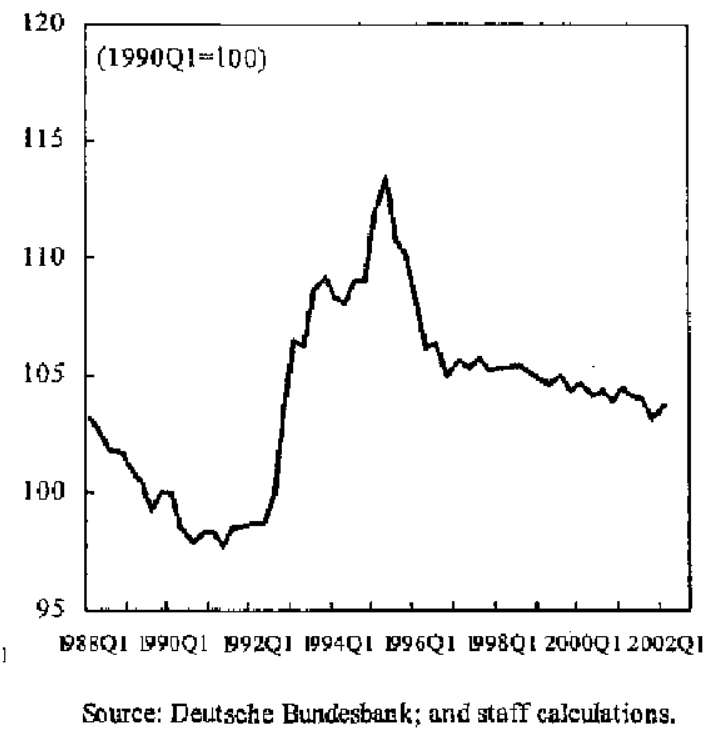

Figure Il-4b. Germany: Real Effective Exchange Rate Based on Unit Labor Cost in Business Sector, 1988-2002

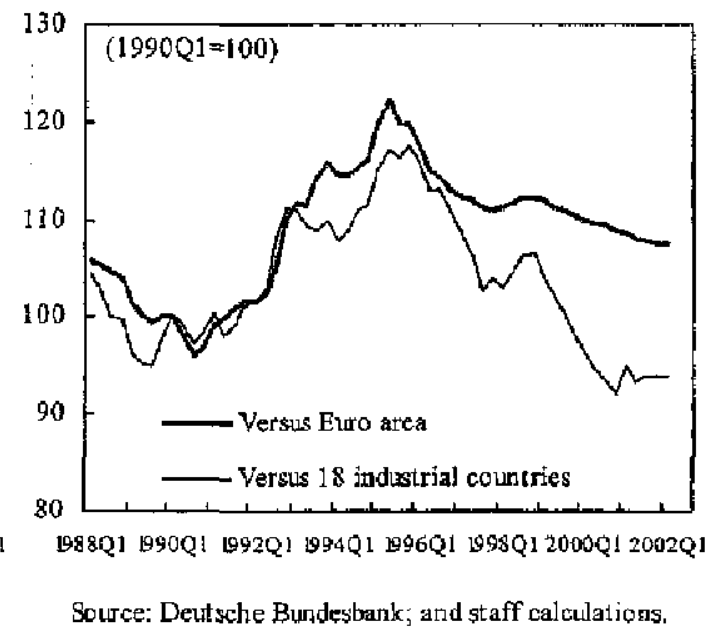

manufacturing sector in Germany uses relatively more labor input from the service sector as well as relatively more imported intermediate inputs than other countries. However the picture of competitiveness looks similar using either manufacturing or business sector data. U.S. Bureau of Labor Statistics estimates reach a similar conclusion regarding labor cost trends between Germany and her trading partners in Europe. 
73. With nominal exchange rates within the euro area essentially pegged in the second half of the 1990s, and wages slow to adjust, employment bore the brunt of adjustment to the earlier real appreciation. During the 1990 s, the downsizing of manufacturing employment was more dramatic than its main euro-area partners (Figure II-5). This in turn raised productivity substantially, reducing unit labor costs. However, manufacturing output also experienced a severe shakeout in the 1993 recession, strinking the size of an important part of Germany's export base.

\section{Relative profitability measures suggest that} competitiveness losses against euro area partners were stemmed around the middle of the $1990 \mathrm{~s}$, although they do not point to a subsequent significant improvement. Profitability is arguably the most direct way to measure competitiveness within the tradable sector, however data availability is a severe limitation. ${ }^{49}$ Crude estimates of profitability for the business sector suggest that Germany's profitability did not improve on average in the first half of the $1990 \mathrm{~s}$, in contrast to similar measures for Germany's main euro area trading partners (Figure II-6). In the second half of the 1990 s, a recovery in profitability in Germany has broadly followed that of the other countries.

\section{With Germany's competitiveness within} Europe on an improving track as EMU approached, the analysis does not provide a definitive answer as to whether Germany pegged at an uncompetitive rate. When exchange rates within the ERM settled down during the latter part of 1996 near the convergence rates eventially chosen, it seems likely from real exchange rate measures that Germany was slightly uncompetitive. But, given the ongoing adjustment in the manufacturing sector, any misalignment would have shrunk by the time of EMU in 1999. Other research has suggested that any overvaluation at the time of unification was probably small. ${ }^{50}$

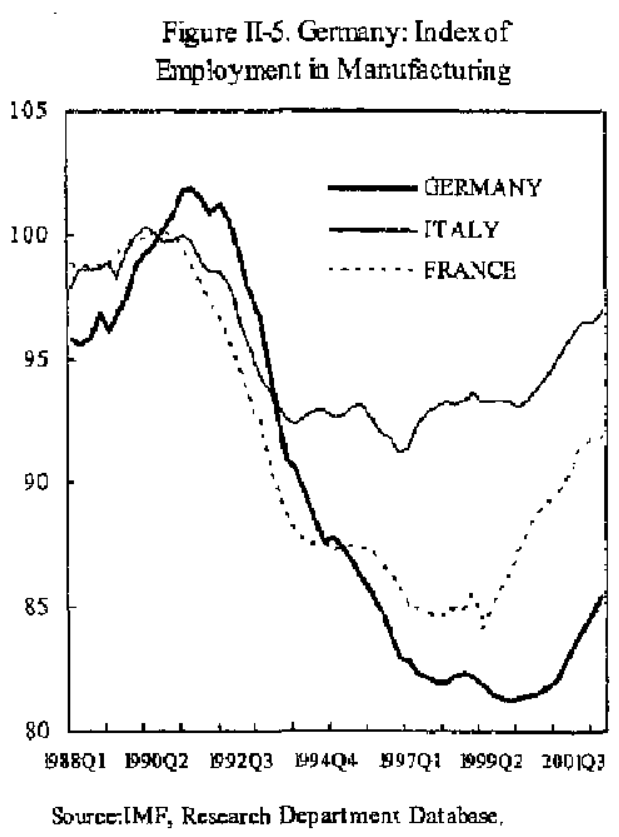

Figure II-6. Selected European Countries: Business Sector Profitability L 1/ 1988-2001

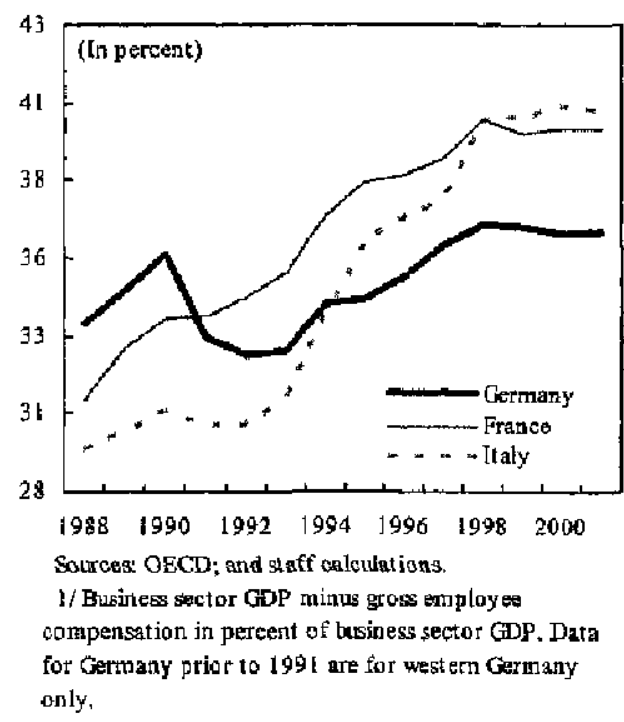

${ }^{49}$ See Lipschitz and McDonald (1991).

${ }^{50}$ For example, Alberola et al (1999) conclude that the deutsche mark was overvalued at entry by only about 3 percent--not a measurably significant amount. 
76. In summary, the various indicators suggest that competitiveness is currently comfortable on a multilateral level-in fact, it is favorable relative to longer-run trends-but Germany's competitiveness within the euro area is more ambiguous. Manufacturing sector data suggest the post-unification loss of competitiveness against euro area partners has yet to be fully reversed, even with the severe shakeout of employment, and relative profitability is still below its level in 1990. And though leaner, the manufacturing sector, and hence a key part of the export base, has shrunk.

\section{B. The Macrobalance Approach}

77. The macrobalance approach provides an alternative framework for assessing competitiventess by utilizing information on the external balance of payments and other macroeconomic data. REER measures only allow for assessment of changes/trends in cost or price competitiveness: no "appropriate level" can be inferred. The macrobalance approach assesses the level of the REER consistent with internal and external balance of the economy. ${ }^{51}$ The framework compares the underlying current account balance with a measure of the equilibrium current account, or, equivalently, the savings-investment balance (the "SI-norm"). The underlying current account is essentially the actual balance adjusted for differences in cyclical demand positions between Germany and her trade partners and the pass-through of lagged exchange rate changes. An underlying current account surplus below equilibrium is evidence of an overvalued or uncompetitive exchange rate.

78. The SI-norm depends on structural and institutional features of the economy, such as the demographic profile and the underlying fiscal position, relative to other countries. Following IMF (2001), it is estimated here as the following partial-adjustment equation:

$\mathrm{CUR}=\mu_{\mathrm{i}}+\lambda \mathrm{CUR}_{1}+\beta_{1} \mathrm{SUR}+\beta_{2} \mathrm{DEM}+\beta_{3} \mathrm{YPCAP}+\beta_{4} \mathrm{GAP}$

where CUR is the current account to GDP ratio, YPCAP is the income per capita, and SUR is the fiscal surplus (as a ratio to GDP), DEM is the dependency ratio, GAP is the output gap (as a ratio to potential GDP) all relative to their respective industrial country averages, and the $\mu_{\mathrm{i}}$ are country-specific coefficients. The latter include a set of dummy variables to capture the effects of unification from 1990 to 1996 . The model is estimated with annual data for 21 industrial countries from 1972 to 2002 (staff estimates for 2002), using a fixed-effect, pooled, time-series regression. After rearranging (1) and assuming output gaps close, the long-run equilibrium current account balance (as a percent of GDP) or SI-norm is:

$\mathrm{CUR}=c_{\mathrm{f}}+\gamma_{1} \mathrm{SUR}+\gamma_{2} \mathrm{DEM}+\gamma_{3} \mathrm{YPCAP}$

where $c_{i}=\mu_{i} /(1-\lambda)$ and $\gamma=\beta /(1-\lambda)$.

${ }^{51}$ See IMF Occașional Paper 167 (1998) and IMF Occasional Paper 209 (2001). 
79. The underlying current account balance is derived from a trade elasticities model. Again following IMF (2001), the parameters and lag structure of the determinants of the current account (the real exchange rate, domestic and foreign dentand) are imposed according to the following:

$$
\begin{aligned}
\mathrm{CA} / \mathrm{Y}_{\mathrm{UND}} & \left.=\mathrm{CA} / \mathrm{Y}-\left[(\mathrm{M} / \mathrm{Y}) \beta_{\mathrm{m}}+(\mathrm{X} / \mathrm{Y}) \beta_{\mathrm{x}}\right)\right]\left[0.3\left(\mathrm{R}-\mathrm{R}_{\mathrm{I}}\right)+0.35\left(\mathrm{R}_{-1}-\mathrm{R}_{-2}\right)\right. \\
& \left.+0.15\left(\mathrm{R}_{-2}-\mathrm{R}_{-3}\right)+0.1\left(\mathrm{R}_{-7}-\mathrm{R}_{4}\right)+0.05\left(\mathrm{R}_{-4}-\mathrm{R}_{-5}\right)+0.05\left(\mathrm{R}_{5}-\mathrm{R}_{-6}\right)\right] \\
& +(\mathrm{M} / \mathrm{Y})\left(\psi_{\mathrm{m}}\right) \mathrm{YGAP}-(\mathrm{X} / \mathrm{Y})\left(\psi_{\mathrm{x}}\right) \mathrm{YGAPF}
\end{aligned}
$$

where $M, X$, and $Y$ represent the nominal domestic currency values of imports, exports, and GDP, respectively; YGAP is the logarithm of the ratio of real output to potential output for the economy in question; YGAPF is the trade-weighted average of gaps for competitors; $\mathrm{R}$ is the logarithm of the real multilateral exchange rate in terms of relative prices of unit labor costs; $\beta_{\mathrm{m}}$ is the long-run elasticity for imports with respect to the real exchange rate (set here at 0.92 ); $\beta_{\mathrm{x}}$ is the equivalent value for exports (set at 0.71 ); and $\psi_{\mathrm{m}}$ and $\psi_{\mathrm{x}}$ are the elasticities of real imports and exports with respect to activity (both set at 1.5). The underlying current account is then derived by removing the effect of domestic and foreign output gaps and adjusting for the pass through of past real exchange rate changes.

80. The results shows that the current account was below its long-run equilibrium value for much of the late $1990 \mathrm{~s}$, consistent with weak competitiveness in this period (Figure II-7). After unification, the current account swung from a sizable surplus into deficit. Smoothing for cyclical and exchange rate pass-through effects, the underlying current account balance initially deteriorated by more than the actual balance, peaking at a deficit of about $2 \frac{1}{2}$ percent of GDP in 1994 . This compares with an estimated equilibrium surplus of around $1 \frac{1}{2}$ percent of GDP. However, the actual and underlying current account balance improved substantially during the 1990 s and by $2000-01$ were in line with equilibrium.

\section{The improvement in the underlying current account position suggests that the real exchange rate has returned to equilibrium on a multilateral basis following a period of overvaluation. This is broadly in line with the conclusion from the analysis of trends in real exchange rate measures and profitability. While that analysis had suggested that Germany is, on a multilateral basis, fairly competitive from a historical basis, the margin of error for both frameworks is wide: nonetheless, on balance, both suggest that overall competitiveness is currently not problematic. Note that the macroeconomic balance estimates depend on the specification of unification dummy variables, assumed here to have a transitory impact on the equilibrium current account surplus. ${ }^{52}$ If the effect is assumed to be}

52 The dummy variables here are specified for the period 1991 to 1996 , although only the dummy for 1991 is statistically significant at the 5 percent level. By contrast, the Bundesbank maintains dummies starting in $1990 \mathrm{Q} 3$ through the end of 1998 when modeling the underlying current account balance. See Bundesbank (2001). 
more persistent, the equilibrium surplus would be lower and competitiveness would appear more favorable. In addition, the model ignores terms of trade effects. For example, the recent deterioration of the terns of trade due to higher oil prices might understate the underlying current account balance if the terms of trade shift proves transitory. ${ }^{53}$

Figure II-7. Germany: SI Norm and Underlying Current Account,

$1984-2001$

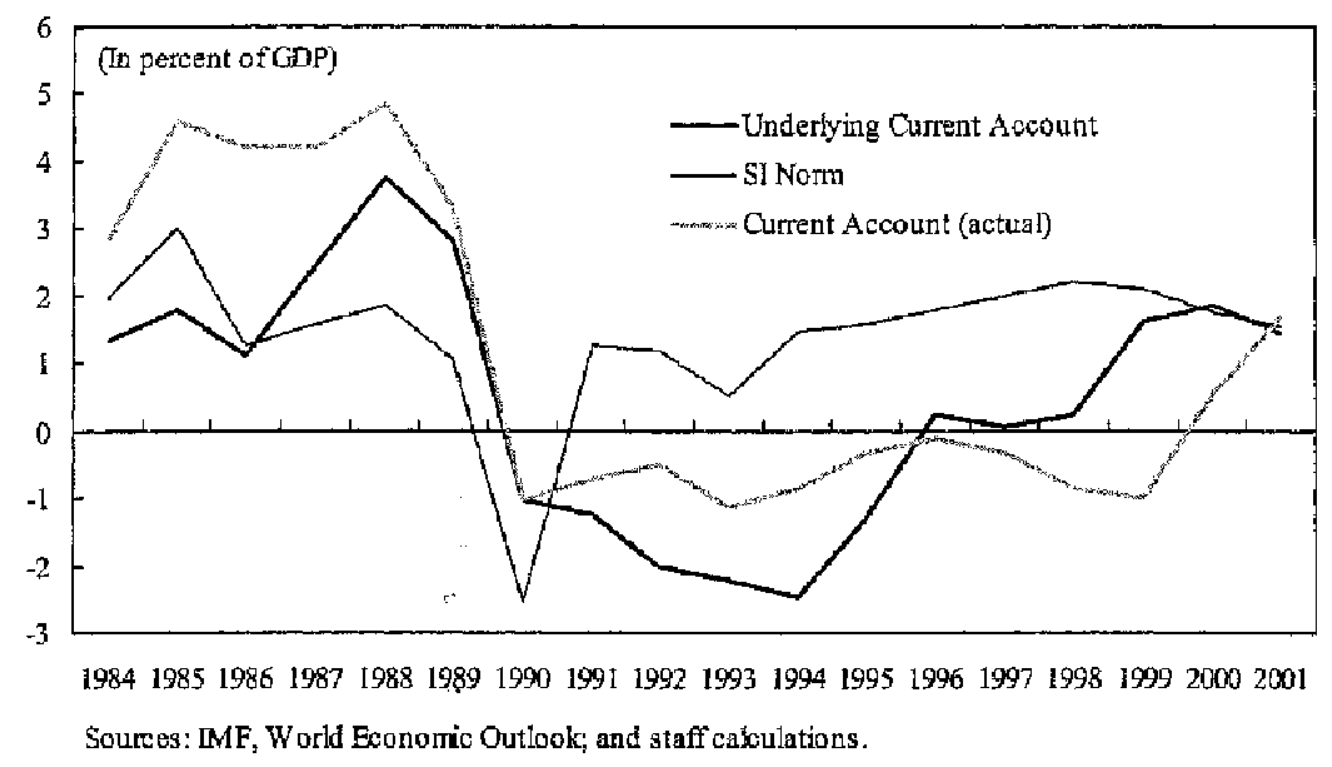

82. The estimates say nothing directly about competitiveness with the euro area, although implicitly the results point in the same direction as those arising from the analysis of trends in effective exchange rates. A similar exercise for the euro area as a whole suggests that the euro is below its ionger-term equilibrium value against other major currencies. Despite this, Germany real effective exchange rate is only broadly in equilibrium suggesting that competitiveness does not draw its strength from within the euro area.

\section{Export Market Shares}

83. Loss of market share provides alternative evidence of a loss of competitiveness. ${ }^{54}$ That said, there can be circumstances in which either market share gains or losses say little

${ }^{53}$ Bundesbank Monthly Report (January 2001) provides more analysis of the terms of trade, which need to be seen in their longer term context. In their absorption model of the external current account, a deteriorating terms of trade elicits over time a positive response from net real exports which tends to offset the price impact effect.

${ }^{54}$ Lipschitz and McDonald (1991): "Underlying the analysis is the presumption that an indicator of competitiveness should possess one critical property: when it points to a loss of competitiveness by a country, the producers of traded goods in that country should see an erosion of their shares in both domestic and foreign markets." 
about competitiveness as previously measured. For instance, nominal export market shares may increase if the terms of trade improve without a change in the real exchange rate. Or some elements, such as the quality of traded goods and services, which are not included in measures of competitiveness, may influence market shares.

84. Germany's share of industrial countries' and the euro area's markets for imported goods declined during the early $1990 \mathrm{~s}$ but has stabilized or rebounded slightly since mid-1997 (Figure II-8). The compositional changes, however, are relatively small with most movements within a one standard error either side of Germany's longer-term average market share. Improvements in the terms of trade from mio-1997 to 1999 also distort somewhat the nominal figures. Broader trends in Germany's geographical direction of trade reflect both globalization effects and bilateral exchange rate movements. Germany's trade is increasingly with developing countries. But within industrial countries, the share of exports going to the United States and United Kingdom have risen owing to the strength of the dollar and the pound.

Figure II-8. Germany: Export Market Shares within Various Regions, $1980-2001$
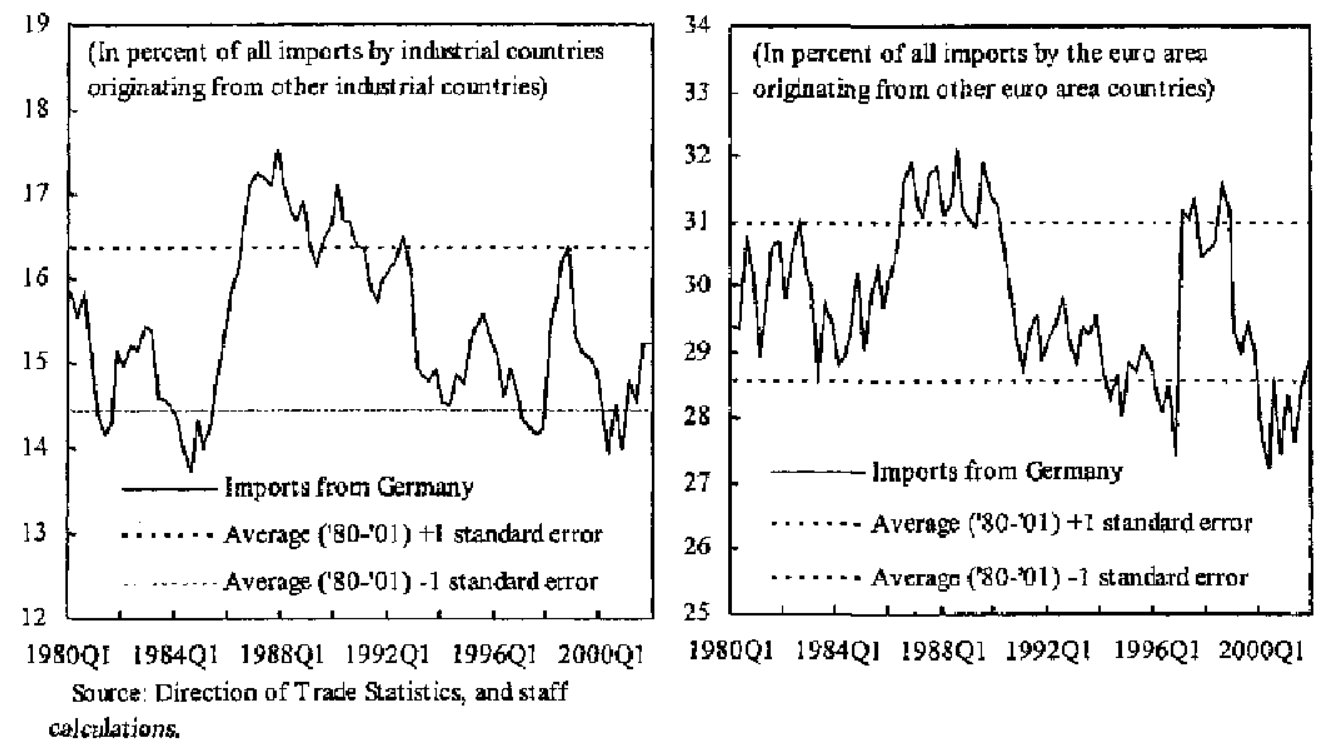

85. The trade share analysis confirms the earlier conclusions about competitiveness, although the data are highly volatile. The recovery of Germany's export market shares in the euro area has been slow and recent improvement has been modest. However, it appears the decline during the 1990 s has been arrested and trade shares are starting to improve. This is consistent with a lagged response to the steep real exchange rate appreciation in the early 1990 s and its subsequent unwinding. 


\section{References}

Alberola, Enrique, Susana G. Cervero, Humberto Lopez, and Angel Ubide, 1999, "Global Equilibrium Exchange Rates: Euro, Dollar, "Ins," "Outs," and Other Majority Currencies in a Panel Cointegration Framework," IMF Working Paper 99/175 (Washington: International Monetary Fund).

Deutsche Bundesbank, Monthly Report, November 1998, "The Indicator Quality of Different Definitions of the Real External Value of the Deutsche Mark," (Frankfurt, Germany), pp. 34-52.

Monthly Report, January 2001, "Structural Current Account Balances: Longer-Term Trends and Determinants," (Frankfurt, Germany), pp. 51-61.

Monthly Report, August 2002, "The Economic Scene in Germany in Summer 2002: Foreign Trade and Payments," (Frankfurt, Germany), pp. 42-51.

Isard, Peter and Hamid Fanuqee, 1998, Exchange Rate Assessment: Extensions of the Macroeconomic Balance Approach, MMF Occasional Paper No. 167 (Washington: International Monetary Fund).

Hamid Faruqee, G. Russell Kincaid, and Martin Fetherston, 2001, Methodology for Current Account and Exchange Rate Assessments, IMF Occasional Paper No. 209, (Washington: International Monetary Fund).

Lipschitz, Leslie and Donogh McDonald, 1991, "Real Exchange Rates and Competitiveness: A Clarification of Concepts, and Some Measurements for Europe," IMF Working Paper 91/25 (Washington: International Monetary Fund).

United States Bureau of Labor Statistics, 2000, "News: International Comparison of Hourly Compensation Costs For Production Workers in Manufacturing, 1998," (Washington: Bureali of Labor). 


\section{The Slowdown IN CREdT Growth ${ }^{55}$}

\section{A. Introduction and Summary}

86. Recent weakness in credit growth would appear to go beyond what can be explained by cyclical factors. Credit growth in Germany has all but balted in recent quarters and has been much weaker than elsewhere in the euro area (Figure III-1). Moreover, crude regressions of credit growth on GDP growth and interest rates predict that credit growth should have been stronger than it was, particularly since mid-2000 (Figure III-2). With the banking system under pressure due to low profitability, high cost bases, and deteriorating credit quality, some commentators have sought to place the blame on the unwillingness of banks to supply credit. Early adoption of credit risk management techniques forthcoming in Basel II capital requirements are also thought to be playing a role. This chapter seeks to determine whether there has been a supply-induced fall in credit growth by examining the explanatory role of various credit-risk variables that might be related to banks' decisions to provide loans.

\section{The chapter finds that various} econometric models fail to account for the depth of the credit slowdown. Identifying a stable credit supply function proved particularly problematic. This may be because the credit-risk variables chosen are not suitable proxies for the tightened credit conditions that firms claim to have experienced. Alternatively, changes over the years in lending practices and the structure of firms? financing may not be properly captured. Turning to the demand side, the evidence that the credit slump is related to the particular weakness of domestic demand and investment in the current downturn is also not convincing. In the final analysis, a significant portion of credit weakness is unexplained.
Figure ill-1, Growth of Private Domestic Credit to Non-Banks in Germany and the Euro Area $\mathrm{h} /$

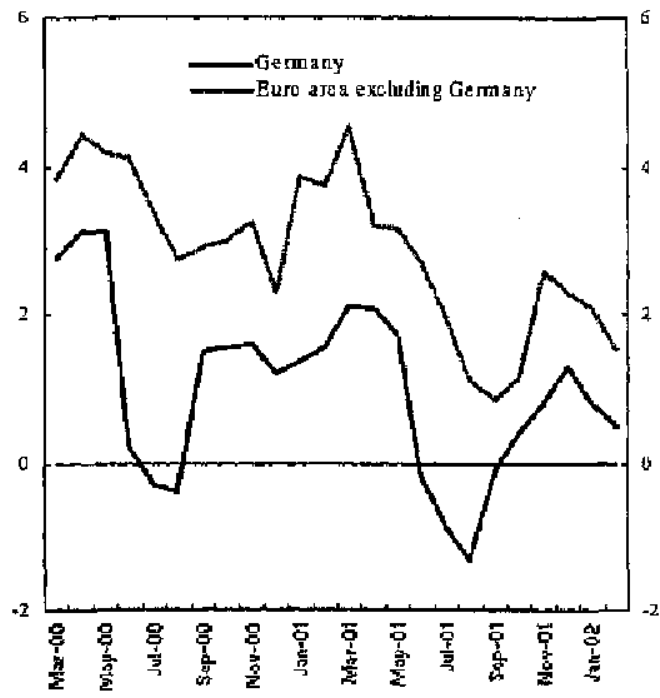

So urce: Deuts che Bundes ba ak.

y Eud of period, qua nex-o n-quarter pefeche change.

Figure III-2, Actual vs Projected Credit Growth $1 /$

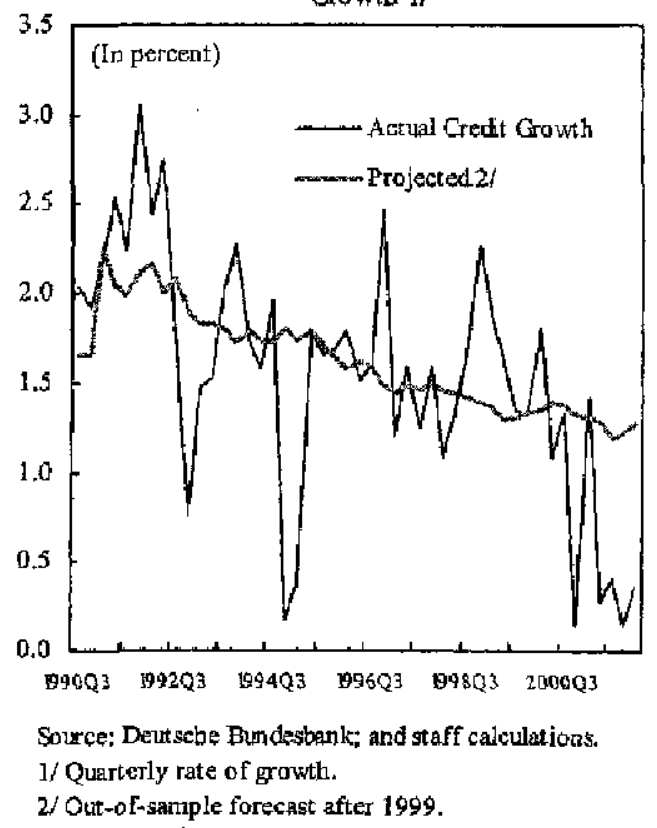

${ }^{55}$ Prepared by Laura Kodres. 


\section{B. Background}

88. Germany remains a bank-dominated financial system and thus credit markets are crucial for the financing of new investment. While year-to-year fluctuations are large and there has been a downward trend in the use of bank credit over the last decade, flow-offunds data show that loans still made up about 55 percent of external financing for nonfinancial corporations in 2000. Other means of financing increased in importance during the $1990 \mathrm{~s}$, but public equity financing and debt issuances remain relatively rare for most German firms. This is especially true for small and medium-sized enterprises (SMEs), called the Mittelstand in Germany, which make up about 80 percent of all businesses. The flotation costs are too high relative to the amount of funds that stich enterprises want to raise.

Publicly-traded equity of limited-liability companies amounted to only 6.3 percent of all nonfinancial corporations external financing, and bonds amounted to a mere 1 percent in 2000 . Other types of private equity (participating interests in corporations and in partnerships) used for financing, which include own funds accumulated by privately-held enterprises (retained earnings), amounted to 31 percent of external financing in 2000 .

89. There are many banks and many types of banks in Germany making the lending environment highly competitive. Interest rate margins, the difference between lending and borrowing rates for banks, are very low and are declining (Figure III-3). Recent attempts by banks to reduce their dependence on revenues from lending margins by entering into more commissionbased businesses have recently hindered, not helped, the problem of low profitability. Revenues from equity market trading, share and bond issuance, and other investment banking businesses have dropped off during the recession. Thus, profitability has been and continues to be very low it international comparison. In addition to falling revenues, the current recession has implied rising costs due to higher provisions as corporate bankruptcies have increased to record levels.

\section{Against the background of chronically}

low profitability, international efforts to revise the regulations for credit risk capital in the form of a "Basel If Accord" have added new impetus for German banks to improve their credit risk management systems. While it is unclear whether the new rules will require German banks, on average, to hold more regulatory capital, the specter of the new regulations has spurred the development of a centralized data base and credit risk measurement tools by banking associations for their members. These new tools have raised the consciousness among banks whose previous credit management policies were not wellattuned to the risks of their clients. This appears to have been particularly true for the smaller banks serving the Mittelstand. The Mittelstand, in turn, has feared that the price of credit 
would rise if more risk-based lending practices were adopted and have successfully lobbied for various changes to the initial drafts of Basel II. These changes effectively exclude the smallest of them from the capital requirements or treat small businesses more leniently within the new methodology linking risk measures to capital. Nonetheless, anecdotal evidence suggests that, within the last year, loan terms and conditions have tightened. A broad survey of Mittelstand companies reports that a majority of respondents found that obtaining bank financing had become more difficult. ${ }^{56}$ This set of events suggests that the drop in credit growth may have a supply-induced component, even though the improvement in risk management policies will ultimately lead to a better functioning lending market.

\section{Modeling Credit Growth}

91. The analytical approach centers on a search for systematic supply-side influences on credit growth. This is done through estimating structural and non-structural models of credit growth that incorporate variables that might be expected to shift the credit supply curve. Non-equilibrium explanations of weak credit growth, in which credit is not priced properly and is implicitly rationed, are also possible. However, such models go beyond the scope of this chapter. ${ }^{57}$ Alternative definitions of credit and economic activity are tried in the various models to test whether credit weakness might stem from either an overly narrow definition of credit or from the particular composition of demand in the current downturn.

\section{The structural model}

\section{The structural model specifies separate equations for the supply of and demand} for credit. Nominal credit (CR) demand is assumed to depend positively on an activity variable (nominal GDP) and negatively on the lending rate (LEND). Supply depends positively on the spread between lending and deposit rates (LEND-DEP) and, depending on their specification, positively or negatively on various credit risk variables (CRISK). ${ }^{58}$ It is these latter variables that would pick up shifts in the credit supply curve. The study uses three credit risk measures: the ratio of capital to assets, the ratio of capital and reserves to assets, and the ratio of provisions to assets. The sign of the coefficient on the first two variables

56 "Wirtschaftslage und Finanzierung im Mittelstand," Creditreform, Spring 2002.

${ }^{57}$ See Laffont and Garcia (1977), Pazarbaşioğlou (1997) and Ghosh and Ghosh (1999) for applications of such models to the analysis of credit markets.

${ }^{58}$ In the literature, the price of alternative financing choices are often included in the demand function: gross operating surplus to represent the cost of internal funds; stock market indices to represent the cost of equity based financing; and the commercial paper rate. Since the use of other types of financing for German firms are quite limited, only the lending rate is used here. Some model formulations also include an activity variable in the credit supply equation. The relative explanatory power of different activity variables is examined below. 
would be expected to be positive to the extent that a high capital ratio might loosen the constraint on loanable funds. However, the opposite sign would be expected if the imposition of higher capital requirements caused banks to scale back lending-a situation evidenced in Japan. ${ }^{59}$ The sign of the coefficient on the provisions ratio would be expected to be negative on the grounds that an increase in provisions would signal a need to rebuild bank capital by foregoing an expansion of credit. In the model, variations in the lending rate are assumed to equate supply and demand. In log-linear form, the model can be represented as:

$\ln \left(C_{t}\right)^{\text {DEMAND }}=\alpha_{0}+\alpha_{1} \ln \left(G_{D P}\right)-\alpha_{2} L_{E N D}$

$\ln \left(\mathrm{CR}_{\mathrm{t}}\right)^{\mathrm{SUPPLY}}=\beta_{0}+\beta_{1}\left(\mathrm{LEND}_{\mathrm{t}}-\mathrm{DEP}_{\mathrm{t}}\right)+\beta_{2} \mathrm{CRISK}_{\mathrm{t}}$

where $\ln ($.$) refers to the natural \log$ of the variable and trefers to time.

93. Estimation of the structural model must address two problems that could cause parameter estimates to be inconsistent: endogeniety, especially of the lending rate; and the non-stationarity of some of the data series. ${ }^{60}$ The first problem is solved by instrumental variable techniques - a two-stage least squares (2SLS) procedure in which the lending rate is replaced by its fitted value from a regression of the lending rate on all the variables in the system. For the non-stationarity problem, one response would be to respecify the model in logged first differenees. However, additional tests pointed to the co-integration of credit with GDP and interest rates, suggesting that an error correction model (ECM) framework for credit demand was appropriate. The model was thus estimated in the following form:

$$
\begin{aligned}
\operatorname{Din}\left(\mathrm{CR}_{\mathrm{t}}\right)^{\text {DEMAND }}=\beta_{0} & +\beta_{1}\left[\ln \left(\mathrm{CR}_{\mathrm{t}-1}\right)-\beta_{11}\left(\ln \left(\mathrm{GDP}_{\mathrm{t}-1}\right)-\beta_{\mathrm{t} 2}\left(\mathrm{LEND}_{\mathrm{t}-1}\right)\right]+\beta_{2} \mathrm{Dln}\left(\mathrm{GDP}_{\mathrm{t}}\right)\right. \\
& +\beta_{3} \mathrm{D}\left(\mathrm{LEND}_{\mathrm{t}}\right)
\end{aligned}
$$

$$
\operatorname{Dln}\left(\mathrm{CR}_{\mathrm{t}}\right)^{\mathrm{SUPPLY}}=\beta_{4}+\beta_{\mathrm{S}} \mathrm{D}\left(\mathrm{LEND}_{\mathrm{N}} \mathrm{DEP} \mathrm{t}\right)+\beta_{6} \mathrm{CRISK}_{\mathrm{t}}
$$

where "D" refers to the difference operator. A dummy variable for the quarter in which unification affected the differenced data was also added to each equation.

\footnotetext{
${ }^{59}$ See Woo (1999).

60 Augmented Dickey-Fuller tests reject a unit root in the differenced series for GDP and credit, but accepts one in the level series suggesting that the two variables are integrated at order one. There is also evidence of unit roots in the lending and deposit rate data, although the test statistics were less significant than for GDP and credit.
} 
94. Estimation fails to uncover well-specified credit demand or supply functions (Table III-1). In the demand equation the high statistical significance of GDP and the significant, negative sign of the speed of adjustment factor, $\beta_{1}$, support earlier evidence for the ECM. According to the model, the long-term elasticity of credit with respect to GDP is greater than unity and deviations from long-term trend credit growth revert to the mean over about nine quarters. But the lending rate is not statistically significant in the long-run adjustment equation, and the coefficient on the change in the lending rate has the wrong sign. In the supply equation, none of the relevant coefficients are statistically significant at the usual five percent level. That said, the coefficient on the interest rate spread has the correct sign - an increase in rnargins would increase the amount of credit supplied. All of the coefficients on the credit risk variables are small and insignificant. The equation using the ratio of capital and reserves to assets shows the most overall promise, with the highest R-bar squared and a spread variable that is significant at the 28 percent level (see Table III-1, column 3).

\section{The poor specification of the model could reflect inappropriate interest rate} variables. The lending rate is an average and may not be representative of the marginal cost of funds to individual borrowers. Recent research has emphasized that to obtain such a link between interest rates and credit, firm-specific data is necessary--that is the investment by an individual firm is (statistically) tied to the lending rate faced by that firm. ${ }^{61}$

\section{The credit-risk variables could also be poor proxies for shifts in credit risk. It} could be that, faced with increased bankruptcies, banks have methods of restraining the supply of credit without altering the quantitative measures available to observe a decline in credit quality. It is well-known that specific provisions and adjustments to reserves in capital are lagging indicators of banking credit risk problems. In general, these variables only start to register deteriorations well after the bank has altered its credit distribution decisions. And, as mentioned above, endogeneity problems make it difficult to assign a priori whether the impact on credit supply of changes in capital ratio variables should be positive or negative.

97. Finally, the model may not capture structural breaks in behavier over time. Such breaks could have occurred on either the lending (supply) or borrowing (demand) side. The gradual decline in the pre-eminence of bank credit financing, for example, is not explicitly modeled by variables to capture the relative attractiveness of various financing options.

${ }^{61}$ See Guiso, Kashyap, Panetta, and Terlizzese (2002). 
Table III-1. Structural and Non-Structural Equation Results ${ }^{1 /}$

\begin{tabular}{|c|c|c|c|c|c|}
\hline Variable & $\begin{array}{c}\text { Demant } \\
\text { Relation } \\
\text { (Equation } 1 \text { ) }\end{array}$ & & $\begin{array}{c}\text { Supply Relation } \\
\text { (Equation 2) }\end{array}$ & & $\begin{array}{c}\text { Non-structural Model } \\
\text { with ECM } \\
\text { (Equation 3) }\end{array}$ \\
\hline Constant & $\begin{array}{l}-0.03768 \\
(-1.7761)\end{array}$ & $\begin{array}{l}0.005766 \\
(0.3559)\end{array}$ & $\begin{array}{l}0.007699 \\
(0.4392)\end{array}$ & $\begin{array}{l}0.01291 \\
(1.5479)\end{array}$ & $\begin{array}{l}-0.07053 \\
(-3.4819)\end{array}$ \\
\hline Error Correction Coefficient & $\begin{array}{l}-0.04949 \\
(-3.0309)\end{array}$ & $\ldots$ & $\cdots$ & $\cdots$ & $\begin{array}{c}-0.112 \\
(5.2159)\end{array}$ \\
\hline $\ln (\operatorname{GDP}(t-1))$ & $\begin{array}{c}1.2400 \\
(30.2804)\end{array}$ & $\cdots$ & $\ldots$ & $\ldots$ & $\begin{array}{c}1.331 \\
(46.9615)\end{array}$ \\
\hline $\operatorname{LEND}(\mathrm{t}-\mathrm{L})$ & $\begin{array}{l}0.007440 \\
(0.7083)\end{array}$ & $\ldots$ & $\cdots$ & $\ldots$ & $\begin{array}{l}0.004009 \\
(-1.1298)\end{array}$ \\
\hline$D \ln (\operatorname{GDP}(t))$ & $\begin{array}{l}0.07391 \\
(1.4835)\end{array}$ & $\cdots$ & $\ldots$ & $\cdots$ & $\begin{array}{l}0.08952 \\
(1.9358)\end{array}$ \\
\hline $\mathrm{D}(\mathrm{LEND})$ & $\begin{array}{l}0.004201 \\
(2.2441)\end{array}$ & $\ldots$ &. & $\ldots$ & $\begin{array}{l}-0.00134 \\
(0.7673)\end{array}$ \\
\hline D(LEND-DEP) & $\ldots$ & $\begin{array}{l}0.008269 \\
(0.9340)\end{array}$ & $\begin{array}{l}0.00971 \\
(1.0932)\end{array}$ & $\begin{array}{l}0.007436 \\
(0.8744)\end{array}$ & $\cdots$ \\
\hline LEND-DEP & $\cdots$ & $\cdots$ & $\ldots$ & $\cdots$ & $\begin{array}{l}-0.00281 \\
(-2.1041)\end{array}$ \\
\hline Capital Asset Ratio & $\cdots$ & $\begin{array}{l}0.002225 \\
(0.4293)\end{array}$ & $\cdots$ & $\cdots$ & $\cdots$ \\
\hline (Capital + Reserves)/Assets & $\ldots$ & $\cdots$ & $\begin{array}{l}0.001561 \\
(0.4103)\end{array}$ & $\ldots$ & $\begin{array}{c}-0.01507 \\
(-3.50064)\end{array}$ \\
\hline Specific Provisions/Assets & $\cdots$ & $\cdots$ & $\ldots$ & $\begin{array}{l}0.002218 \\
(0.2509)\end{array}$ & $\cdots$ \\
\hline Dummy $^{2 f}$ & $\begin{array}{c}0.08286 \\
(13.1689)\end{array}$ & $\begin{array}{c}0.08582 \\
(10.9638)\end{array}$ & $\begin{array}{c}0.08579 \\
(10.5914)\end{array}$ & $\begin{array}{c}0.08659 \\
(11.4257)\end{array}$ & $\begin{array}{c}0.08167 \\
(14.9034)\end{array}$ \\
\hline R-Bar Squared & 0.740 & 0.666 & 0.668 & 0.664 & 0.781 \\
\hline
\end{tabular}

Source: Staff estimates.

1/ $\mathrm{T}$-statistics in parentheses below coefficient estimate; standard error adjusted for use of fitted value in 2SLS approach.

2/ Durany variable for unification. 


\section{A less-structured model}

98. Given the difficulties of specifying supply and demand, an alternative approach is to estimate a less structurally constrained model. This approach places all the previously considered determinants of credit growth into a single equation. It is essentially a reduced form of the supply and demand model-although interest rates were also included in the specification on the grounds that they may include independent information that would help to explain and forecast credit growth. Guided by the estimation results and the time series properties of the data, the following ECM formulation was used:

$$
\begin{aligned}
\operatorname{Dln}\left(\mathrm{CR}_{t}\right)=\beta_{0} & +\beta_{1}\left[\ln \left(\mathrm{CR}_{\mathrm{t}-1}\right)+\beta_{11} \ln \left(\mathrm{GDP}_{\mathrm{t}-1}\right)+\beta_{12} \ln \left(\mathrm{LEND}_{\mathrm{t}-1}\right)\right]+\beta_{2} \mathrm{D} \ln \left(\mathrm{GDP}_{\mathrm{t}}\right) \\
& +\beta_{3} \mathrm{D}\left(\mathrm{LEND}_{\mathrm{t}}\right)+\beta_{4}\left(\mathrm{LEND}_{\mathrm{t}} \mathrm{DEP}_{\mathrm{t}}\right)+\beta_{5} \mathrm{CRISK}_{\mathrm{t}}
\end{aligned}
$$

99. Estimation finds that the supply-side variables add explanatory power, although their interpretation in the credit equation is not clear. Compared to the structural demand equation, the fit is somewhat better as reflected in a higher R-bar squared (see Table III-1). Interest rates and credit risk variables all have negative and statistically significant coefficients. However, the negative coefficient on interest rate spreads is hard to interpret and seems to suggest a dominant demand-side effect. The negative coefficient on the capital ratio variable lends some credence to the view that banks respond to falling capital ratios by foregoing lending. ${ }^{62}$ The sign on the specific provisions is the hypothesized sign-higher provisions would be associated with decreased growth of credit. Given the likelihood of endogeneity problems, the results should be viewed warily.

100. The model still does not explain recent credit developments well. The overprediction of credit growth is slightly smaller than that of the demand equation. Based on the within-sample fit, the cumulative overprediction of credit over the last year is 211 basis points for the non-structural model compared with 229 basis points using the demand equation alone (Figure III-4). In out-of-sample forecasts based on estimating the model through 1999 Q4, the overprediction is 339 basis points in the non-structural model versus 375 basis points for

Figure III-4. Model Projections of Credit Growth $1 /$

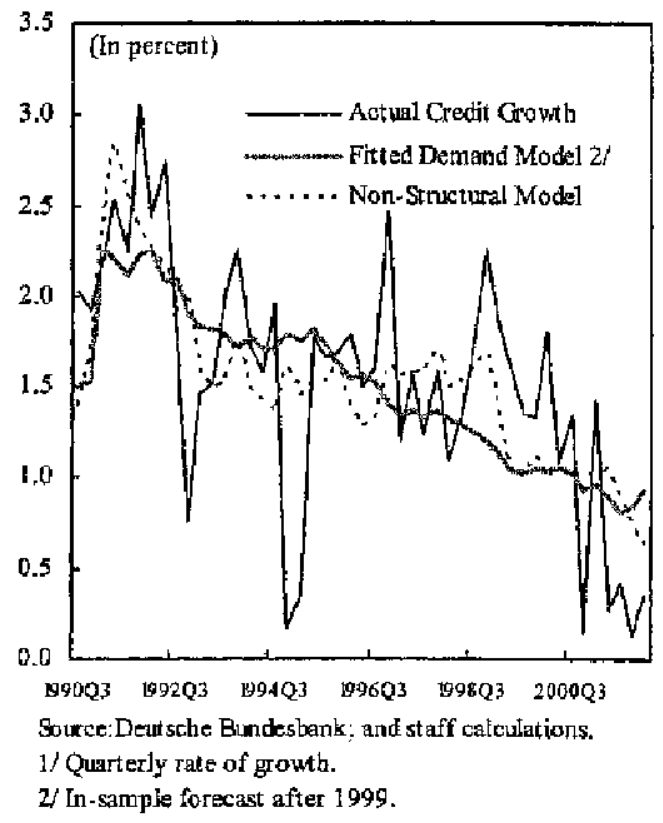

62 There is no evidence, however, that the authorities have encouraged or mandated higher capital and reserves than are already required in the EU Directive that implemented the Basel I Capital Accord. 
the demand equation. Formal F-tests weakly confirm there is a structural break in the equation at the end of 1999 . In sum, the addition of the supply-side variables does not repair the failings of simple credit demand equations.

\section{Alternative definitions of credit and activity}

101. The failure to explain recent credit growth could reflect either that the credit variable is too narrowly defined or that GDP is a poor proxy for activity. On the specification of credit, firms have in recent years increasingly chosen means of borrowing that are not recorded in the standard measures of domestic bank's loans to the non-financial sector. In particular, firms are borrowing through their foreign subsidiaries from banks in the host country or utilizing trade credit. Sometimes these are German banks operating abroad, but often they are foreign banks which provide cheaper credit to the subsidiary or affiliate. The subsidiary or affiliate then transfers the funds to the parent. The strong growth in such lending in recent years is visible through the balance of payment statistics (Figure III-5). Nonetheless, using an augmented credit variable in both the structural and non-structural models led to worse fits.

Figure III-5. Gemany: Total Ljabilities of Non-Financial Enterprises

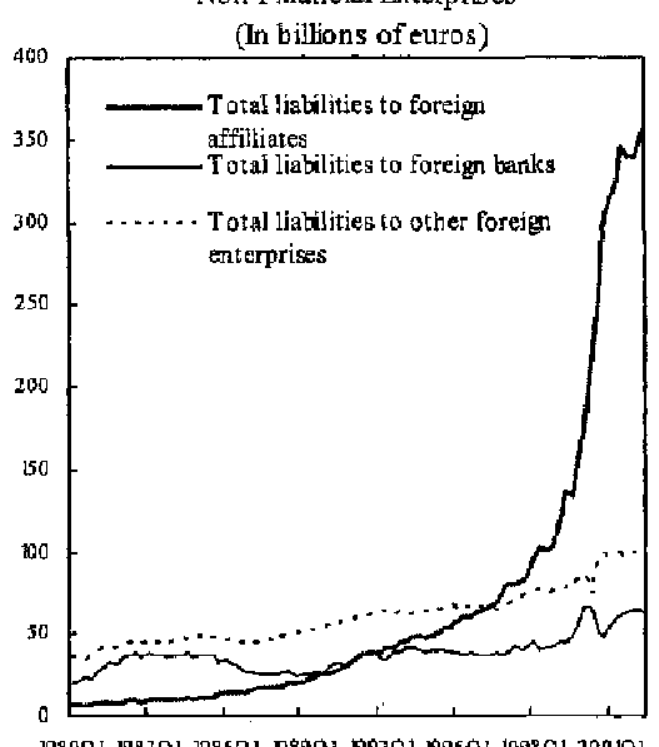

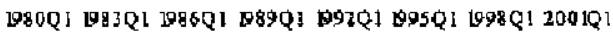
Sources: Deutsebe Bundesbank.

\section{Alternative measures of economic activity also fail to explain the overprediction} of recent credit growth. While GDP is a conventional choice for the activity variable in credit equations, other variables could in practice work better. In the current downturn, for example, it is reasonable to question whether the particular weakness of domestic demand and investment has played a role in the credit slowdown. Replacing GDP with total domestic demand in the credit models improved the full-sample fit of the non-structural model somewhat - the variance of credit growth explained rose to 81 percent, compared with 78 percent when GDP was the activity variable. However, the equation's out-of-sample forecast performance deteriorated: if the model is estimated through 1999Q4 and used to predict credit in the next five quarters, the cumulative overprediction of credit rises to 5 percent of the initial level of credit, compared to about $3 \frac{1}{2}$ percentage points when GDP is used. Investment and total domestic demand plus exports were also tried as alternative activity variables, but neither improved the fit or forecast performance of the non-structural model. 


\section{Conclusions}

103. The steep drop off in credit growth cannot be fully explained by simple models. On the one hand, credit weakness goes beyond what can be explained by demand factors, including the particular structure of demand in the recent downturn. On the other hand, efforts to pinpoint supply-side factors are disappointing. This mayy reflect the inadequateness of available measures of credit risk as well as other aggregation and specification problems. However, a structural break in credit supply in response to a need to improve credit risk management cannot be ruled out. This possibility would appear more likely if the current weakness in the growth of credit relative to activity were to persist. 


\section{Data Sources and Definitions}

104. Nominal credit is defined as credit granted to non-financial institutions from the domestic banks and comes from the Bundesbank's Banking Statistics (Bankenstatistiks). The augmented credit series include non-financial firms' borrowing from foreign banks, firm's borrowing through foreign affiliates, and borrowing from other foreign enterprises (comprising mostly trade credit). These data come from the Balance of Payments Statistics (Zahlungsbilanzstatistik). The lending rate is the rate assigned on medium-sized loans (between $€ 100,000$ and $€ 500,000$ ). The spread variable is the spread of the lending rate on medium-size loans over the deposit rate on medium-sized one-month time deposits (between $€ 50,000$ and $€ 500,000$ ). These interest rate data are taken from the Bundesbank's Monthly Report. Data on the credit-risk variables-the amount of capital as a proportion of total assets, the amount of capital plus reserves as a ratio to total assets, and the amount of provisions to total assets--all come from the Bundesbank's Banking Statistics (Bankenstatistiks). The data are sampled quarterly from 1980Q1 to 2002Q1. 


\section{References}

Ghosh, S.R and A.R. Ghosh, 1999, "East Asia in the Aftermath: Was There a Crunch?," IMF Working Paper 99/38 (Washington: International Monetary Fund).

Guiso, Luigi, Anil K. Kashyap, Fabio Panetta, Daniele Terlizzese, 2002, "How Interest Sensitive is Investment? Very (when the data are well measured)," Working Paper, University of Chicago, (Chicago, Illinois).

Laffont, J.-J. and R. Garcia, 1977, "Disequilibrium Econometrics for Business Loans," Econometrica, Vol. 45, No. 5, pp. 1187-1204.

Pazarbaşioğlou, Ceyla, 1997, "A Credit Crunch? Finland in the Aftermath of the Banking Crisis," Staff Papers, International Monetary Fund, Vol. 44, No. 3, pp. 315-327.

"Wirtschaftslage und Finanzierung im Mittelstand," Creditreform, Spring 2002, (Neuss, Germany).

Woo, David, 1999, "In Search of "Capital Crunch": Supply Factors Behind the Credit Slowdown in Japan," IMF Working Paper 99/3 (Washington: International Monetary Fund). 


\section{The Fiscal Challenge Of Aging: What neEds to Be Done ${ }^{63}$}

\section{A. Introduction and Results}

105. Demographic aging is increasingly being recognized as the major long-term policy challenge (Gruber, 2001 and Pfeiffer, 1999). Attempts to quantify the fiscal ramifications and possible policy responses in a comprehensive and coherent way, however, remain sparse. This chapter tries to put a price tag on all age-related public spending items and to project against this background the evolution of government finances over the next fifty years under present policies and alternative scenarios. Unsurprisingly, aging is found to put severe pressure on public finances, adding an estimated 6.7 percent of GDP to expenditure. Present consolidation efforts under the Stability Program and beyond help to mitigate the strains but would be both insufficient in the long run and difficult to implement in the nearer term unless they involve reform of entitlement and age-related spending programs.

106. Despite several studies on the aging problem it remains difficult to get a quantitative sense of the size of the fiscal challenge ahead. Quantifications on the part of the OECD (Dang et al., 2001), the Economic Policy Committee (2001), and the European Commission (2001) are not truly comprehensive: they consider only certain, but not all, agerelated spending items and they do not integrate the analysis into a broader long-term fiscal outlook. Other studies stick to a mainly qualitative assessment, such as the final report of the Enquete Commission of Germany's lower house of parliament (2002). There appears to be no study that accounts for all spending items that are severely affected by aging, incorporates recent policy commitments to fiscal consolidation over the next couple of years, and assesses the evolution of public deficits and debt in light of the constraints imposed by the Stability and Growth Pact (SGP). A recent Bundesbank working paper comes closest (Manzke, 2002). It utilizes generation accounting techniques to calculate the so-called sustainability gap, i.e., the amount of sustained fiscal adjustment needed now for the government's intertemporal budget constraint to hold.

\section{This chapter attempts to fill the analytical gap by constructing very long-term} fiscal projections to get a practical sense for the size of the problem and to evaluate policy options. Fiscal developments in the near term are mainly driven by the government's consolidation effort; developments in the outer years are dominated by demographics. The approach dissects expenditure into age-related spending, i.e., items that are highly sensitive to demographic change, interest payments, support for the unemployed, and all other expenditure. Age-related spending comprises (i) public pensions; (ii) civil service pensions; (iii) health care expenditure; (iv) long-term care for the elderly; and (v) child-related expenditure.

${ }^{63}$ Prepared by Christoph Klingen. 
108. The long-run challenge notwithstanding, demographics are unlikely to make themselves very much felt over the next 10 to 15 years. Through 2015 the total dependency ratio, i.e, the number of the elderly and the young relative to the population at econonically active age, will rise only mildly, to 63 percent compared to 61 percent in 2000 .

109. Age-related spending is likely to increase relative to GDP by 6.7 percentage points over the next fifty years on account of demographic factors (Figure $[V-1$ ). Such spending accounted for 23.7 percent of GDP in 2001 . Under present policies it is projected to remain roughly at this level through 2015, experience a steep increase between 2015 and 2030 , and to level off at 30.4 percent of GDP in 2050 . The bulk of the strain comes from the public and civil service pension systems, which add 5.1 percent of GDP and 1.0 percent of GDP, respectively, to expenditure. The projected increase in pension spending includes the effect of the recent pension reform, which provides some relief to benefit growth mainly in 2002-09. Health care and long-term care for the elderly contribute 1.3 percentage points and 0.7 percentage points, respectively. Child-related expenditure provides relief equivalent to 1.4 percent of GDP.

110. Factors other than demographic ones might further augment the increase of agerelated spending. This is particularly true of health care expenditure where technological change in medicine might very well add to cost pressures. The calculations of this chapter do not account for such effects and focus more narrowly on demographically induced expenditure increases. Besides, it would be very difficult to estimate the quantitative impact of technical change, even if the direction of the effect is quite clear. In the event, the overall increase of age-related spending would likely be higher than 6.7 percent of GDP if all factors were taken into account and not just demographic ones.

\section{The fiscal challenge of aging should be addressed as soon as possible even if the} main demographic onslaught on public finances is not yet imminent. First, it would be prudent to enter the hot phase of demographic transition with room for budget deficits and public debt to grow rather than with the back against the wall of SGP limits. This would avoid the need for drastic corrective measures and send a timely signal to financial markets that society has recognized the problem and is dealing with it. Second, implementing substantial reform requires significant lead time. Socio-political consensus must be forged and households need to be given time to adjust to new realities. This is especially true for pension benefits, on which people base long-run economic plans and decisions. Third, the economy's potential growth should be higher in the next 10 to 15 years before demographics inevitably slows it down. Implementing fiscal consolidation in the relatively fat years rather than the relatively lean years should be less difficult. 


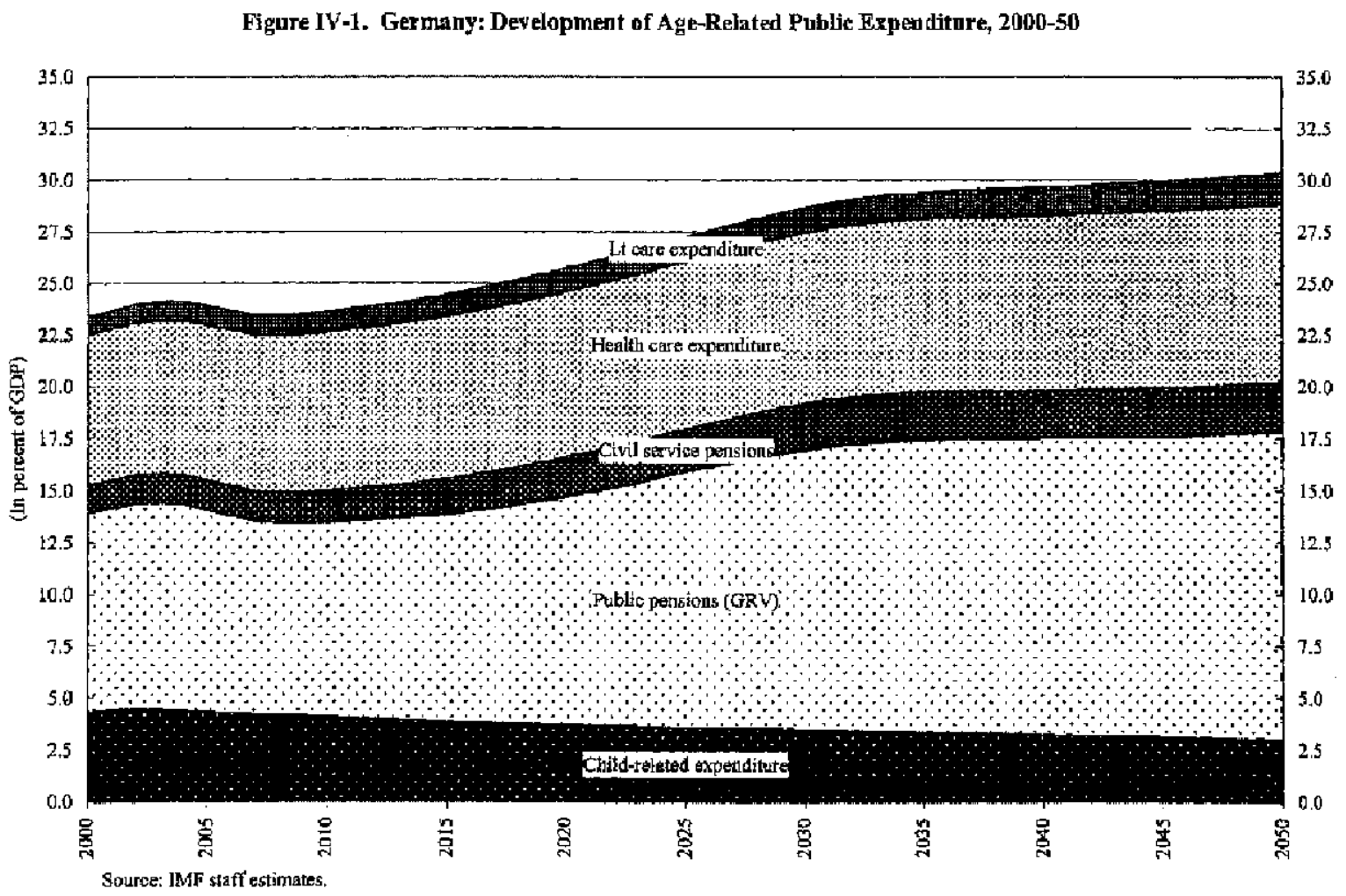

112. If policy makers fail to deliver front-loaded expenditure restraint or entitlement reform, public finances could spin out of control very quickly unless social security contribution rates are raised to unacceptable levels. Public debt and deficits would escalate if the government adopted a neutral stance, i.e., if it (i) simply held constant the ratio to GDP of all expenditure other than age-related spending, unemployment support, and the interest bill; (ii) absorbed the cost of already approved tax cuts; (iii) did not reform agerelated spending programs further; and (iv) refrained from tax increases (see "nonconsolidation scenario" in Table $\Gamma-1$ and Figures $\Gamma-2$ and $\Gamma-3$ ). Indeed, to offset the deterioration of public finances one would need to raise social security contribution rates to almost 65 percent by 2050 , from 41.3 percent currently. ${ }^{64}$ Such rates would probably be close to confiscatory given that income taxes would come on top.

\section{Strong consolidation efforts over the next few years, as envisaged by the} authorities' Stability Program, create room to accommodate future demographic spending pressures, but are insufficient to safeguard public finances in the long run. In

\footnotetext{
${ }^{64}$ More concreteiy, the increase of social security contribution rates in this and subsequent scenarios is calibrated so that deficit and public debt comply with SGP limits throughout the projection period and the deficit is contained at $1 \frac{1 / 2}{2}$ percent of GDP in 2050 , thus ensuring a reasonable safety margin to the three-percent-of-GDP deficit limit.
} 
line with current commitments, the "stability program scenario" assumes that the general government deficit is reduced to close to balance in 2004 in structural terms - the headline deficit approaches balance only by 2007 when the output gap will have closed according to the macroframework used here. Consolidation is brought about entirely by permanent retrenchments in other expenditure, ${ }^{65}$ which declines to 16.7 percent of GDP from 20 percent of GDP at present. While this ensures compliance with the 3-percent-of-GDP deficit ceiling through 2020, social security contribution rates would still need to be hiked to 56 percent to stabilize public finances through 2050 (see "stability program scenario" in Table IV-I and Figures IV-2 and IV-3).

114. Even extending the fiscal effort so as to reach a surplus equivalent to 1 percent of GDP by 2009, as envisaged in the Government's Fiscal Guidelines (Federal Ministry of Finance, 2000), would not stabilize public finances over the projection horizon. Other expenditure would then need to be compressed to around 15 percent of GDP, from 20 percent of GDP at present. This would keep the deficit ratio below 3 percent of GDP well into the 2030 s, but a modest increase of social security contribution rates would still be needed to contain the deficit ratio through 2050 (see "fiscal guidelines scenario" in Table IV-1 and Figures IV-2 and 3). Indeed, it would take an augmentation of surpluses to almost 2 percent of GDP by 2012 to avoid additional social security contribution hikes altogether. This in turn would require a reduction of other expenditure to some 14 percent of GDP (see "enhanced fiscal guidelines scenario" in Table IV-1 and Figures IV-2 and 3).

115. The effectiveness of front-loaded consolidation hinges primarily on the permanency of the underlying savings measures rather than the up-front reduction of public debt. True, in the "enhanced fiscal guidelines scenario" public debt declines substantially (to 43 percent of GDP by 2012 from around 60 percent of GDP presently) and this relieves the interest bill, which falls to 2.4 percent of GDP from 3.2 percent of GDP in 2001. But such interest savings are a drop in the bucket compared to the rise of age-related spending by 6.7 percent of GDP. Moreover, interest savings are only partly available for accommodating other spending - were they spent in full, debt would build up again and interest savings would wither away. The "transitory consolidation scenario," illustrates that a strategy that targets surpluses with less than fully sustainable savings measures can provide only false comfort. As the "enhanced guidelines scenario" it achieves a budget surplus of 1.9 percent of GDP by 2012 through curtailment of other expenditure to 14.3 percent of GDP. Thereafter, however, savings partly unravel and other expenditure creeps back to 17.2 percent of GDP. Public finances become unsustainable and it would take a hike of social

${ }^{65}$ The government has yet to decide which expenditure prograns to scale back under the Stability Program. However, retrenchments in the area of age-related spending seem not be on the agenda, with the possible exception of health care. But even there reform efforts are primarily about avoiding a further escalation of the expenditure ratio rather than unearthing a contribution to fiscal consolidation under the Stability Program. 
security contribution rates to 57 percent to rein in the deficit (see "transitory consolidation scenario" in Table IV-1 and Figures IV-2 and IV-3).

Table TW-1. Geranany: General Goverument Operatlons, 2001-50

\begin{tabular}{|c|c|c|c|c|c|}
\hline \multicolumn{6}{|c|}{ Non-zonoalidation Seenario } \\
\hline & 2001 & 2005 & 2015 & 2030 & 2050 \\
\hline & \multicolumn{5}{|c|}{ (in pertent of GDP) } \\
\hline Revenue & 46.7 & 45.7 & 43.8 & 45,0 & 45.1 \\
\hline Expendiure & 48.3 & 48.9 & 50.5 & 61.7 & 80.9 \\
\hline Age relared & 23.7 & 23.9 & 24.5 & 28.7 & 36,4 \\
\hline Unemployment support ti & 1,4 & 1,4 & 1.2 & 1,7 & 1.2 \\
\hline Interest & 3.2 & 3.3 & 5.0 & 11.5 & 29.1 \\
\hline Other & 20.0 & 20.4 & 20.3 & 20.3 & 20.3 \\
\hline Babnce & -1.7 & -3.2 & -7.1 & -16.7 & -35.8 \\
\hline Public debt & 59.5 & 62.3 & 94.9 & 220.5 & 5540 \\
\hline
\end{tabular}

Fixcal Guidelines Scenario

\begin{tabular}{|c|c|c|c|c|c|}
\hline & 2001 & 2065 & 2015 & 2030 & 2050 \\
\hline & \multicolumn{5}{|c|}{ (In percant of GDP) } \\
\hline Revenut & 45.5 & 44.2 & 43.8 & 45.0 & 45.5 \\
\hline Expenditure & 48.3 & 45,8 & 42.9 & 46.8 & 51.0 \\
\hline Age related & 23.7 & 23.9 & 24.5 & 28.7 & 30.4 \\
\hline Unesmpioyment suppont $1 /$ & 1.4 & 1.4 & 1.2 & 1.2 & 1.2 \\
\hline Interest & 3.2 & 3.2 & 2.1 & 1.7 & 4.3 \\
\hline Other & 26.0 & 17.3 & 152 & 15.2 & 15.2 \\
\hline Batance & 2.8 & -1.6 & 0.9 & -1.7 & -5.9 \\
\hline Pablic debt & 59.5 & 59.9 & 38.3 & 32.8 & 81.6 \\
\hline
\end{tabular}

Trassimry Consoldation Scenario

\begin{tabular}{|c|c|c|c|c|c|}
\hline & 2001 & 2005 & 2015 & 2030 & 2050 \\
\hline & \multicolumn{5}{|c|}{ (In percest of GDP) } \\
\hline Revenue & 45.5 & 44.2 & 43.8 & 45.0 & 45.1 \\
\hline Expetdisure & 48.5 & 45.8 & 45,0 & 51.0 & 599 \\
\hline Aşe related & 23.7 & 23.9 & 245 & 28.7 & 30.4 \\
\hline Unemployrneat $\$$ upport $1 /$ & 1.4 & 1.4 & 12 & 1.2 & 12 \\
\hline Interest & 3.2 & 3.2 & 2.1 & 3.9 & 11.1 \\
\hline Other & 20.0 & 173 & 172 & 17,2 & 172 \\
\hline Balance & -2.8 & -1.6 & -12 & -6.0 & $-14,8$ \\
\hline Public deb1 & 59.5 & 59.9 & 40.3 & 75.0 & 212.6 \\
\hline
\end{tabular}

Stability Program Scensarto

\begin{tabular}{|c|c|c|c|c|c|}
\hline & 2001 & 2005 & 2015 & 2030 & 2050 \\
\hline & \multicolumn{5}{|c|}{ (In percent of GDP) } \\
\hline Rovenus & 45.5 & 442 & 43.8 & 45.0 & 45.1 \\
\hline Expendiure & 48.3 & 45.8 & 45.0 & 50.8 & 59.1 \\
\hline Ayce rrlated & 23.7 & 23.5 & 24.5 & 28.7 & 30.4 \\
\hline Unetriployment support $1 /$ & 1.4 & 1.4 & 1.2 & 1.2 & 1.2 \\
\hline Interest & 3.2 & 3.2 & 2.8 & 4.3 & 10.9 \\
\hline Dther & 20.0 & 17.3 & 16.7 & 16.7 & 16.7 \\
\hline Balance & 2.8 & .1 .6 & -12 & -5.8 & $.14,0$ \\
\hline Public dè̀t & 59.5 & 59.9 & 51.4 & B1.5 & 208.4 \\
\hline
\end{tabular}

Enhanced Fbca! Guidelimes Scenario

\begin{tabular}{|c|c|c|c|c|c|}
\hline & 1001 & 2005 & 2015 & 2030 & 2050 \\
\hline & \multicolumn{5}{|c|}{ (Tr pereent of GDP) } \\
\hline Revenue & 45.5 & 44.3 & 43.8 & 45.0 & 45.1 \\
\hline Expenditure & 48.3 & 45.8 & 41.8 & 44.6 & .46 .5 \\
\hline Age related & 23.7 & 23.9 & 24.5 & 28.7 & 30.4 \\
\hline Unemp]oyment suppori I/ & 1,4 & 1,4 & 1.2 & 1.2 & 1.2 \\
\hline Interest & 3.2 & 3.2 & 19 & 0.5 & 0.8 \\
\hline Other & 20.0 & 17.3 & 14.3 & {$[4.3$} & 14.3 \\
\hline Balarce & -2.8 & -1.5 & 2.0 & 0.4 & -1.5 \\
\hline Public deot & 59.5 & $\$ 9.8$ & 33.9 & 8.4 & 14,7 \\
\hline
\end{tabular}

Enttlement Reform Sceenario

\begin{tabular}{|c|c|c|c|c|c|}
\hline & 2001 & 2005 & 2015 & 2030 & 2050 \\
\hline & \multicolumn{5}{|c|}{ (In percent of GDP\}) } \\
\hline Reteme & 45.5 & 44.2 & 43.8 & $4 \$ .0$ & 45.1 \\
\hline Expenditure & 48.3 & 45.8 & 43,5 & 45,3 & 46.6 \\
\hline Age related & 23.7 & 23.1 & 23.1 & 25.7 & $26 . ?$ \\
\hline Wnertiployme be support is & 1.4 & 0.9 & 0.8 & 0.8 & 0.8 \\
\hline unterest & 3.2 & 3.2 & 2.4 & 1.8 & 2.0 \\
\hline Other & 20.0 & 18.5 & 172 & 17.2 & 17.2 \\
\hline Babintice & -2.8 & -1.6 & 0.3 & -9.5 & -1.5 \\
\hline Public deb! & $\$ 9.5$ & $\$ 9.9$ & 44.0 & 34.0 & 36.7 \\
\hline
\end{tabular}


Figure VI-2. Germany: Evolution of Fiscal Deficits and Public Debt, 2000-50

Non-cons olidation Scenario

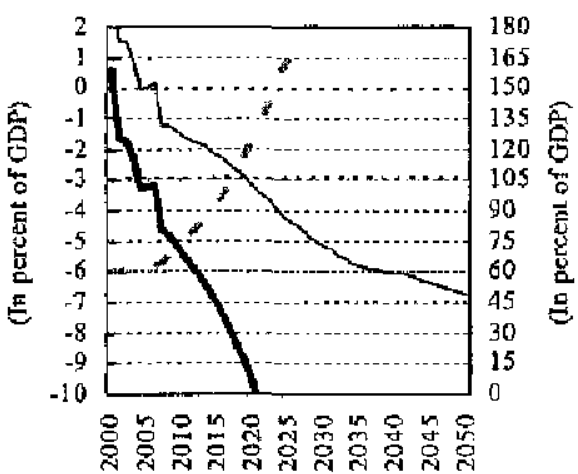

Fiscal Gujdelines Scenario

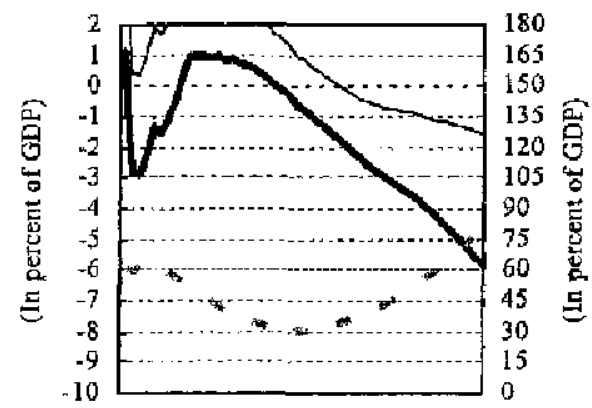

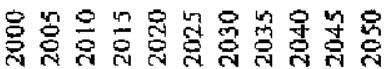

Transitory Cons olidation Scenario

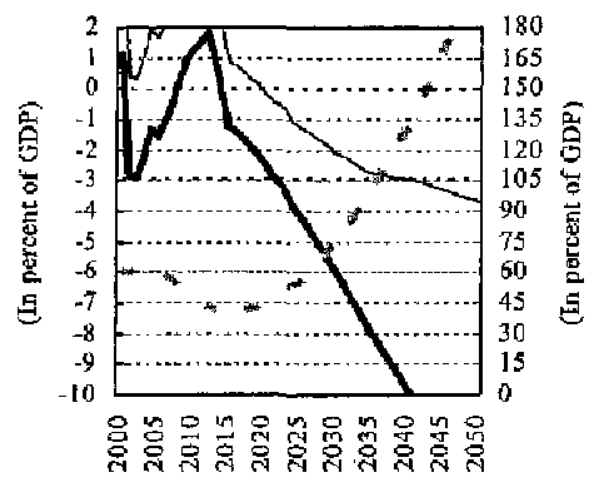

bold black line -- fiscai balance (left scale) black line - primary tiscal balance (left scale) dashed grey line - public debt (right scale)

Source: MP staff estimates.
Stability Program Seenarío

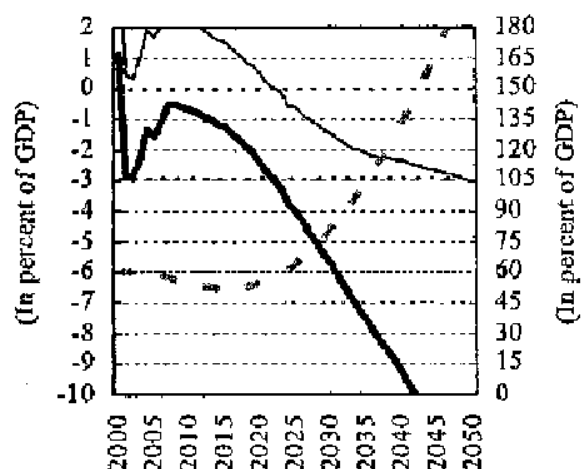

Enhanced Fls cal Guidelines Scenario

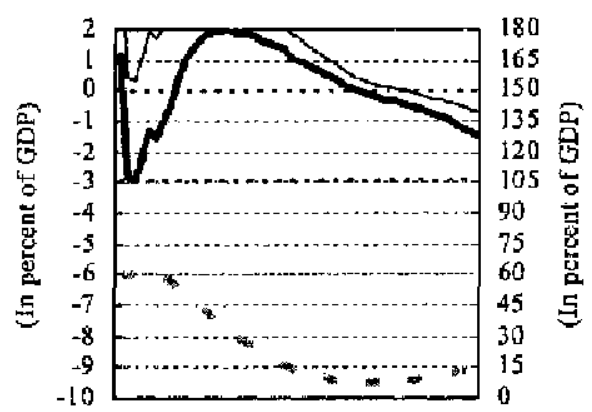

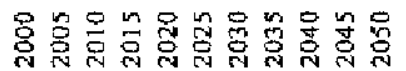

Entitlement Reform Scenario

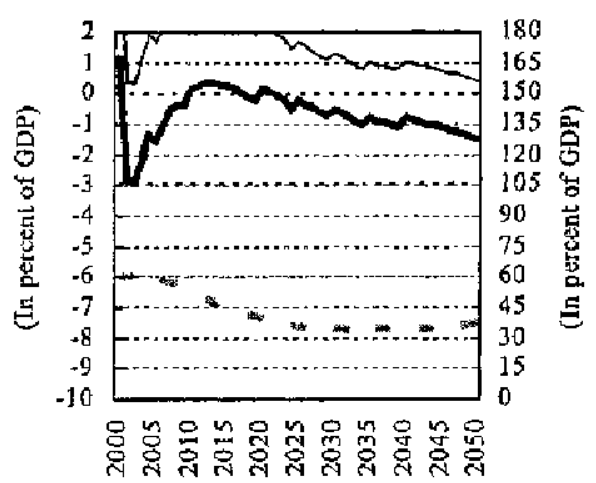


Figure IV-3. Germany: Evolution of Baseline and Required Social Security Contribution Rates, 2000-50 1/

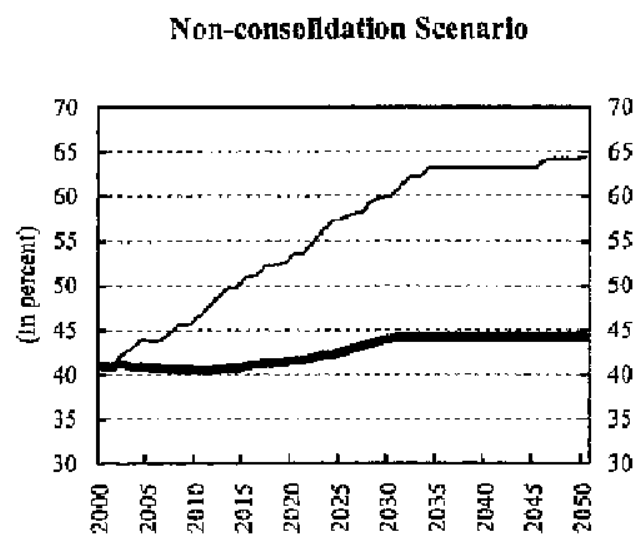

Fiscal Guidelines Scenarío

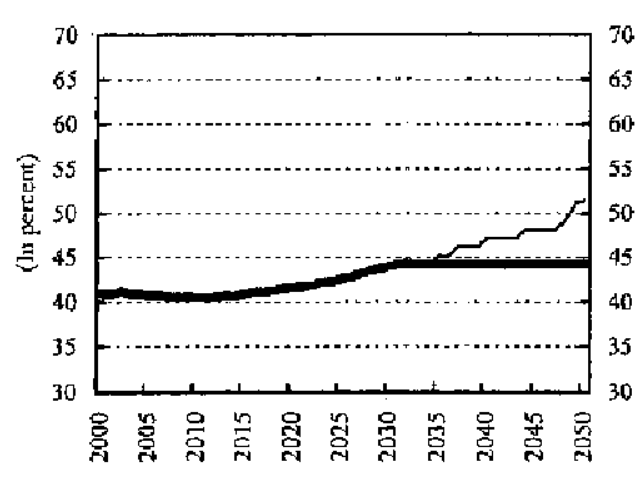

Transitory Consolidation Scenario

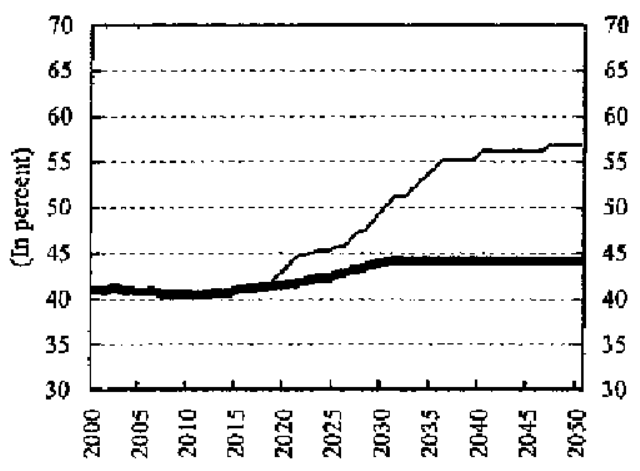

bold line - baseline social secturity contribution rate fine line - required social security contribution rate
Stability Program Scenario

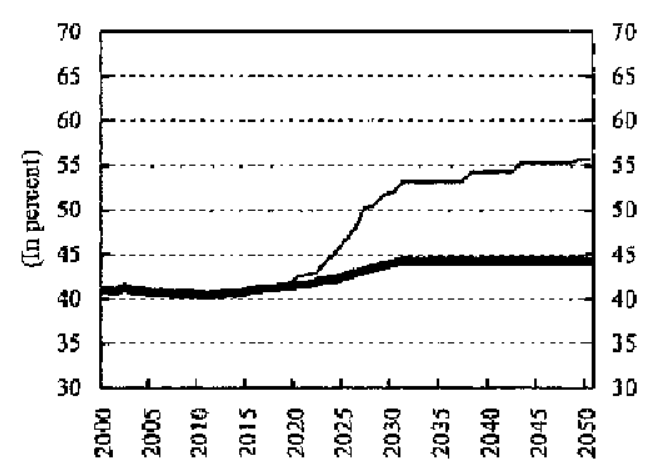

Enhanced Fisca] Guidelines Scenario

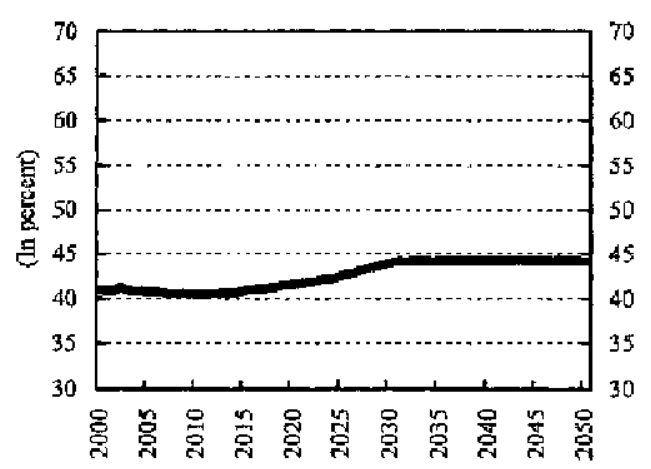

Entitlement Reform Scenarlo

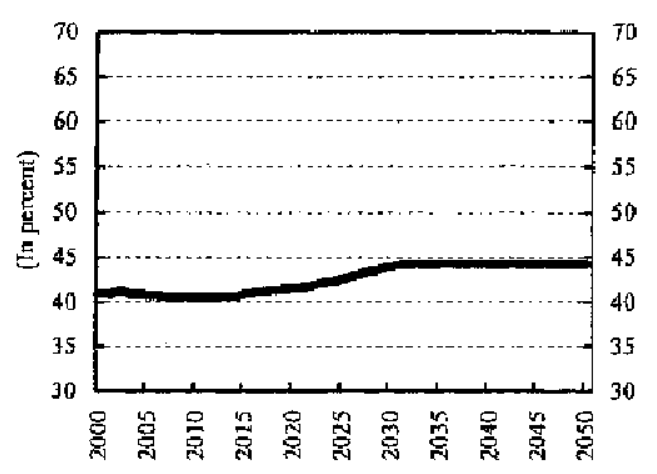

Source: IMF staff estimates.

1/ Rate required for deficit at 1.5 percent of GDP in 2050 and debt below 60 percent of GDP. 
116. The critical importance of permanent savings measures underscores the need for entitlement reform. It is unlikely that other expenditure, i.e., spending other than age-related expenditure, unemployment support and the interest bill, can alone shoulder the entire adjustment need. A lasting reduction of the spending ratio by close to 30 percent, as would be required under the "enhanced guidelines scenario," appears out of reach. Even the retrenchment required in the "stability program scenario" is a formidable challenge. Quantitatively it corresponds to eliminating all public investment and the entire defense budget.

117. Entitlement reform combined with more modest cutbacks in other expenditure thus offers the best hope for complying with Stability Program commitments, ensuring that savings measures are permanent, and managing the long-term fiscal pressures from demographic aging. The "entitlement reform scenario" (see Table IV -1 and Figures IV-2 and IV-3) involves a more reasonable permanent reduction of other expenditure to 17.2 percent of GDP from 20 percent of GDP presently. The following entitlement reforms provide the core of the consolidation effort and ensure sustainable public finances through 2050:

- a reduction of public pension benefits by 5 percent in 2010 and another 5 percent in 2020. This would generate savings of up to 1.7 percent of GDP per year if matched by a commensurate cut for retired public sector employees. It would leave the 2050 replacement ratio at 60 percent compared to 66.6 under current arrangements. The reduction could either take the form of a proportional cut for all pensioners or a differentiated cut, with deeper reductions for pensioners without children and milder reductions for pensioners who have shouldered the private costs of raising children. The differentiated cut would emphasize intragenerational equity and ability-to-pay considerations thus going beyond the traditional intergenerational considerations. Significant reductions would need to be announced weil ahead of time to give households time to build up compensating private savings. But it is important to note that, given productivity growth in the economy, a cut in the replacement ratio would not require cuts in real pension benefits. To the contrary, even with a 10 percent cut in the replacement ratio, real pension benefits in 2050 would be about twice as high as they are today;

- an increase of private households' share in health care financing to 20 percent, from around 10 percent presently, as of 2003 . This would generate savings of up to 0.8 percent of GDP. Budgetary savings could be larger if higher patient co-payments reduced health care demand;

- reform of financial support for the unemployed, so as to reduce average benefit levels by a cumulative 30 percent over the next three years. It would generate direct savings of 0.4 percent of GDP. Cuts could be across the board, take the form of limits on duration of support, or be built into a merger of unemployment and social assistance. Total savings could be significantly larger once the formerly unemployed take up work. If the natural rate of unemployment fell by 1 percentage point, savings would rise to 0.6 percent of GDP, but only over time; 
- an increase of the statutory retirement age for those covered by the public and civil service pension schemes by a total of two years ( $1 / 2$ year in 2025, 2030, 2035, and 2040). This would generate long-run savings of 1 percent of GDP. This quantification assumes an unchanged pension formula and, as a result of expanding employment histories, replacement ratios would actually increase. Simultaneous modification of the pension formula so as to keep replacement ratios constant, would augment savings to 1.7 percent of GDP. Note that retirement periods would still lengthen as the four-year rise of life expectancy outstrips the two-year rise of the retirement age;

- a reduction of the time young people spend in education before joining the labor force by one year. It would generate long-run savings of 0.2 percent of GDP, assuming the demand for labor rose commensurately. No savings would be available on impact, though, as it would take time before the first cohort under the new education regime graduated. Note that the baseline labor force participation rates have built in a further lengthening of time spent in education so that this measure would not mean an actual shortening of current education periods.

118. The window of opportunity to prepare for the strains of demographic aging is closing rapidly. The longer that consolication is postponed, or the more it relies on unsustainable deficit reduction methods, the more drastic measures will need to be in the longer tern to restore healthy public finances. Moreover, it would be very difficult to engineer sufficient front-loaded adjustment without reforming entitlement programs. And, in the long run it would be next to impossible to eschew entitlement reform if public finances are to remain sound.

119. The remainder of this chapter discusses the demographic and macroeconomic assumptions underpinning the projections. It describes in detail the likely evolution of each age-related spending item and how the quantifications here differ from those provided by others. Detailed tables are provided in the Appendix.

\section{B. Assumptions}

120. Expenditure projections for pensions, health, and long-term care funds build on common demographic and macroeconomic assumptions, which also underlie all other expenditure and revenue forecasts. Demographic and macroeconomic projections are integrated. Aging thus affects the fiscal accounts not only directly through increased spending on pensions and health care for the elderly but also indirectly through the effect of a shrinking workforce on economic activity. Projections through 2007 are consistent with the IMF staff's Fall 2002 World Economic Outlook.

\section{Demographic developments}

121. Population projections follow the $9^{\text {th }}$ coordinated population forecast of the German Federal Statistical Office. The central scenario predicts the German population to shrink to 70 million by 2050 , from 82 million in 2000 , assuming immigration of some 
200,000 persons per year. It uses a crude birth rate of 1,400 per 1,000 women, roughly the level now prevailing in westem Germany and significantly more than in eastern Germany (800). Life expectancy at birth is predicted to rise by roughly four years until 2050. It will then be 78.1 years for men and 84.5 years for women.

122. Old-age dependency increases strongly, as the effects of rising longevity, low fertility, and retiring baby boomers compound. While there are currently about 28 elderly (persons aged 65 and above) for every 100 persons aged 20 to 64, there will be an estimated 52 of them in 2050 . Young-age dependency is set to drop. Persons under 20 will decline from 34 currently to 30 for every 100 persons aged 20 to 64 .

123. Despite some relief from young-age dependeney, total dependency is projected to rise relentlessly. The bulk of the increase will occur between 2010 and 2030. At the peak in 2037 , there will be 84 persons at economically inactive age for every 100 persons at economically active age, compared to 61 currently (Figure IV-4). Note that total dependency was on the decline through 1993, a period that in the development-country literature is referred to as a demographic window of opportunity (Merrick, 2002).

Figure IV-4. Germany: Population Dependency Ratios, 1980-2050

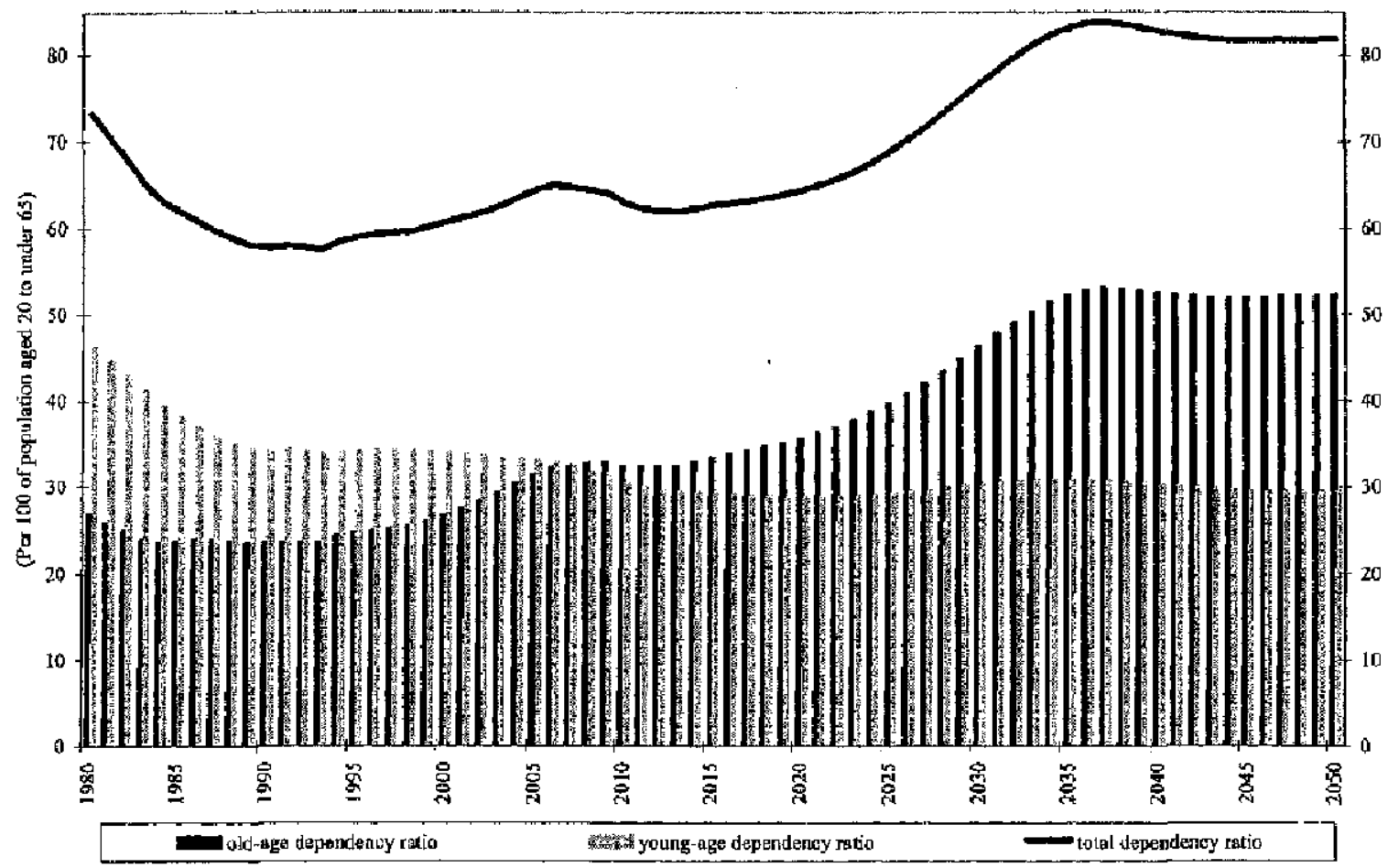

124. Population projections of the Federal Statistical Office are in between those prepared by other institutions. On the back of more pessimistic fertility assumptions, the World Bank projects that the population could shrink to 66 million in 2050. Eurostat on the other hand sees the population in 2050 at 76 million in its central scenario. As fertility rates 
and life expectancy change only slowly over time and affect dependency ratios only with lags of up to several decades, the key uncertainty attaches to immigration assumptions. Immigration of 200,000 persons per year is slightly above Germany's historical average, although yearly numbers fluctuated strongly from as low as $-200,000$ to as high as 800,000 persons.

\section{Macroeconomic environment}

125. Macroeconomic developments over the next five years are assumed to be characterized by economic recovery. After a still weak 2002 performance, growth is projected to accelerate, lifting the 2002-07 average above 2 percent annually. At the same time, unemployment would gradually recede from just over 8 percent on an EU-standardized measure to less than 7 percent. Total factor productivity growth would experience a cyclical boost (Table IV-2).

Table IV-2. Gexmany: Summary of Macroeconomic Developments, 2001 - $\theta 7$

\begin{tabular}{|c|c|c|c|}
\hline & 2001 & 2007 & tverage annual change \\
\hline & & & (In percent) \\
\hline Nominal GDP (billions of Euros) & 2,071 & 2,546 & 3.5 \\
\hline Rea1 GDP (billions of Euros) & 1,981 & 2,248 & 2.1 \\
\hline GDP deflator $(1995=100)$ & 105 & 113 & 1.3 \\
\hline Total factor productivity & $\ldots$ & $\ldots$ & 1.2 \\
\hline Employment (millions) & 38,917 & 39,653 & 0.3 \\
\hline Unemployment rate (percent) 1 & 8 & 7 & $\cdots$ \\
\hline Population (milions) & 82,220 & 81,949 & -0.1 \\
\hline Labor force participation (percent) $2 /$ & 84 & 87 & $\cdots$ \\
\hline Labor productivity & ... & $\cdots$ & 1.8 \\
\hline Compensation per enrployee & $\ldots$ & .... & 2.5 \\
\hline
\end{tabular}

126. For the period after 2007 , cyclical effects are assumed to have run their course and demographic effects make their mark. As of 2010 employment starts to shrink thus turning into a drag on growth. The capital stock is assumed to continue to grow at an annual rate of $2 \frac{1 / 2}{2}$ percent, slightly faster than its historical pace. Total factor productivity growth is pegged at 1 percent, somewhat lower than Germany's long-run performance, but significantly better than in the recent past. As a result of these assumptions, real GDP growth decelerates markedly after 2010 to about $1 \frac{1 / 4}{4}$ percent on average. Labor productivity growth hovers around 2 percent throughout the projection period.

127. The labor share of income is assumed to remain constant from 2007 , after a slight reduction during 2001-2007. While this appears an innocuous enough assumption, it has important implications for the projected increase of age-related spending: if the labor share of income remains constant and employment falls, wage growth outpaces GDP growth and so does pension benefit growth because pensions are indexed to wages. Consequently, pension expenditure expressed as a percent of GDP goes up. Nonetheless, it appears reasonable to have wage growth accelerate as labor becomes scarcer. Moreover, as far as the overall fiscal position is concemed, assuming a shrinking labor share of income instead 
would not necessarily be helpful: true it would relieve public pension expenditure, but at the same time it would erode public revenues as long as labor is taxed more heavily than capital. Carey and Robesona (2002) provide evidence that average effective tax rates on capital are indeed lower than those on labor.

\section{Given population projections, labor force participation and unemployment} drive the evolution of employment. By international standards, labor force participation rates in Germany are already high, around 83 percent in 2000 , so that room for further increases is probably limited. The calculations here utilize age-group and sex-specific labor force participation rate series provided by the ifo-Institute. They imply a further increase of overall participation to 86 percent in 2035 ; thereafter the changing age profile of the population reduces the aggregate participation rate back to 84 percent by 2050 . Changes in age-group specific participation rates have little impact on overall male labor force participation. Higher rates for older men are offset by lower rates for younger men, reflecting the trend to higher education attainments (Table IV-3). For women, shifts in age-group specific participation rates increase the female labor force by almost 10 percent. Participation rates rise for all age-groups, except for younger women, again reflecting rising educational attainment levels.

Table IV-3. Germany: Labor Force Particjpation Rates

\begin{tabular}{|c|c|c|c|c|c|c|}
\hline \multirow{3}{*}{ ABe group } & \multicolumn{6}{|c|}{ Participation Rates (in percent) } \\
\hline & \multicolumn{3}{|c|}{ Male } & \multicolumn{3}{|c|}{ Female } \\
\hline & 2000 & 2050 & Change & 2000 & 2050 & Change \\
\hline $55-20$ & 35.0 & 30.0 & -5.0 & 28.4 & 23.0 & -5.4 \\
\hline $20-25$ & 76.3 & 71.3 & -5.0 & 67.6 & 63.6 & $-4,0$ \\
\hline $25-30$ & 87.8 & 86.3 & -1.5 & 74.3 & 76.8 & 2.5 \\
\hline $30-35$ & 95.8 & 95.9 & 0.1 & 74.6 & 80.3 & 5.7 \\
\hline $35-40$ & 96.8 & 97.2 & 0.4 & 75.7 & 82.7 & 7.0 \\
\hline $40-45$ & 96.3 & 96,8 & 0.5 & 77.9 & 86.7 & 8.8 \\
\hline $45 \cdot 50$ & 95.0 & 95.4 & 0.4 & 77.1 & 85.4 & 8.3 \\
\hline $50-55$ & 91.5 & 91.3 & -0.2 & 69.2 & 85.1 & 15.9 \\
\hline $55-60$ & 77.9 & B4.1 & 6.2 & 53.5 & 65.2 & 11.7 \\
\hline $60-65$ & 33.2 & 39.6 & 6.4 & 14.9 & 16.9 & 2.0 \\
\hline Total $1 /$ & 80.4 & 80.7 & 0.3 & 62.3 & 67.8 & 5.6 \\
\hline
\end{tabular}

129. Although results depend on the underlying set of macroeconomic assumptions, they appear relatively robust. For example, if the exercise of this chapter was instead based on the labor force participation rates projected by the IAB, a research institute attached to the Federal Labor Office, the deterioration of the primary fiscal balance would be a mere 0.1 percent of GDP smaller over the entire fifty year projection horizon. Likewise, a brisker pace of total factor productivity growth or capital accumulation would do little to the fiscal strains from demographic aging. It would simply increase most age-related spending by the same factor as GDP, reflecting the indexing of pension benefits to wages and an income 
elasticity of health care demand pegged at unity. Nonetheless, it would certainly make the necessary fiscal consolidation easier to bear.

\section{The Outlook in Detail}

130. The main demographically induced fiscal pressures will emerge in the areas of the public pension fund, civil service pensions, health care, and long-term care for the elderly. As opposed to many other studies, this section focuses on the expenditure side on these sub-systems, and only on that part that represents expenditure of the consolidated general government. This approach rules out spurious solutions, like keeping the public pension fund solvent through growing transfers from the federal budget, which merely shifts the fiscal strain between levels of government without reducing it. It also allows adding up expenditure of the sub-systems without double-counting because financial flows between them, like the health care contributions paid by the public pension fund, are ignored from the outset.

\section{Public pensions}

131. The public pension fund is the sub-system most severely affected by aging (Figure IV-5). Its expenditure, excluding the health care contributions on behalf on pensioners, is projected to increase relative to GDP by 5.1 percentage points, from 9.7 percent in 2001 to 14.8 percent in 2050 . A slight decline over the next few years, reflecting the recently reformed formula for old-age pension adjustment gives way to a steep increase during the period 2010-30 when the population ages rapidly. Expenditure keeps rising somewhat thereafter as an increasingly large share of newly retiring cohorts becomes entitled to benefits mainly as a result of rising female employment. As old-age, survivor, and disability pensions are subject to quite different dynamics they are projected separately.

132. Old-age pensions account for the bulk of the expenditure increase, 4.8 percent of GDP. The German pension formula that came into force with the 2001 Pension Reform Act ties pension benefits to the evolution of modified gross wages. Modified gross wages are gross wages minus contribution rates to the first pillar of the pension system and the cap on subsidized contribution rates to the second-pillar. In addition, as of 2011 further increases of contribution rates reduce pensions slightly more than proportionately. ${ }^{66}$ In sum, pegging to modified gross wages reduces pension expenditure by about 9 percent compared to an outright link to gross wages, assuming the officially projected trajectory of contribution rates. The growing number of elderly increases pension expenditure by about a third. Rising pension entitlements in the wake of expanding female employment add another 15 percent.

${ }^{66}$ For more details see Sachverständigenrat (2001). 
Figure JV-5. Germany: Public Pension Fund Expenditure, 2000-2050

(Excl, health care contributions and rehabilitation expendirure)

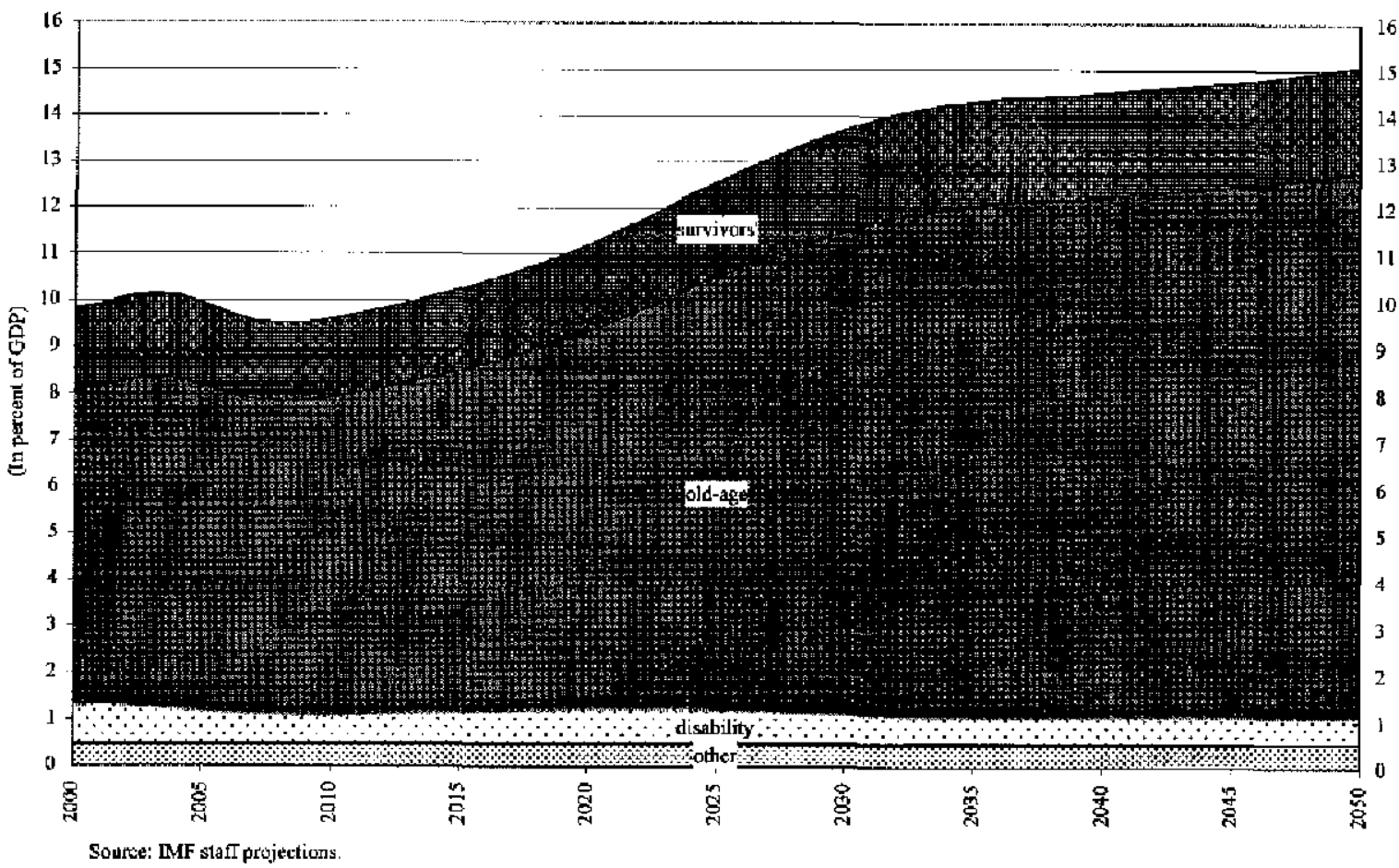

133. As a result of a recent overhaul of disability pensions, expenditure in this category is projected to fall by 0.3 percent of GDP until 2050. Disability pensions are not subject to much demographic pressure as they are paid exclusively to persons who have not yet reached the statutory retirement age. Developments are therefore dominated by reform efforts since 1996, which reduced the generosity of support, some recent back tracking notwithstanding. The quantifications of the associated savings are taken from a study prepared by the ifo-Institute for the Ministry of Finance (Werding and Blau, 200I).

134. Survivors' pension expenditure grows some $\mathbf{2 5}$ percent less than outlays for oldage pensions and adds 0.6 percent of GDP over the next fifty years. In principle survivors' pensions are subject to the same demographic pressures as old-age pensions. But expanding female employment means that widows will increasingly have pensions of their own, which reduces their entitlements under the survivors' pension system. Other recent reforms such as the lowering of the replacement ratio of survivors with dependent children and the introduction of pension rights for time spent bringing up children are not taken into account here. Quantitatively they should be of minor importance and they are at least partially offsetting.

135. Pension expenditure projections are in the ballpark of estimates by others. The projected increase of 5.3 percent of GDP compares to a somewhat higher estimate by Rother et al. (2002) and 4.3 percent by the ifo-Institute (Werding and Blau, 2001). The ifoInstitute projections are also used in the work of the Economic Policy Committee (2001) and the work of the OECD (Dang, Antolin, and Oxley, 2001). Without publishing projections for 
individual countries, the European Commission (2001) reckons that public pension expenditure in the European Union would increase relative to GDP by 7 percentage points if no increase in labor force participation rates occurred. IMF (2000) argued that the pension reform proposal of 2000 would probably not go far enough to ensure contribution rates below the government's target level of 22 percent by 2030 .

\section{Civil service pensions}

136. Expenditure for pensions of government employees are projected to increase relative to GDP by one percentage point, from 1.4 percent currently to 2.4 percent in 2050. As with other pensions, the bulk of the increase takes place between 2010 and 2030 . The 2001 civil service pension reform (Zypries, 2002) scales back the generosity of the benefit formula beginning in 2003 and seeks to match the retrenchments in the public pension system. Nonetheless, the expenditure ratio keeps rising all through the implementation phase as the saving effect is swamped by the rapidly growing number of retired civil servants. Retirement benefits for civil servants are paid from territorial governments' budgets and account for most of the expenditure considered here.

\section{Supplementary retirement systems for government employees without civil} service status also need to be considered (VBL, and AKA). These schemes are mostly payas-you-go, although some modest funded elements are also present. Strictly speaking they are classified outside the general government, as they are entities of private law rather than public law. However, the government as the employer is currently responsible for around 85 percent of the contributions - this fraction of supplementary pension expenditure is thus considered public age-related spending here. Benefits under the supplementary systems are laid down in collective bargaining agreements between the government and government employees' unions. In light of already emerging strains, the supplementary systems were fundamentally overhauled in the context of the 2001 wage round (Stephan, 2002a and Stephan, 2002b).

138. The calculations at hand build on the official projections regarding the number of future beneficiaries, take into account the recent reforms of benefit formulae, and assume that benefits will otherwise be adjusted periodically to reflect wage growth. The Ministry of the Interior (Bundesministerium des Innern, 2001) recently published a comprehensive report on likely future development of beneficiaries and expenditure under the civil service pension funds, including the supplementary schemes. The number of beneficiaries will peek around 2025, when the wave of teachers hired in the 1970s will have retired, and decline slightly thereafter. Adjustments to the civil service pension formula reduces benefit growth by an estimated cumulative 5.6 percentage points during 2000-17. The overhaul of the supplementary pension systems is likely to yield savings of some 20 percent once all transitory arrangements are phased out.

139. This chapter projects more of a fiscal burden from civil service pensions than other studies. The Ministry of the Interior projects an increase relative to GDP by 0.7 percentage points between 2000 and the peak in 2025, and 0.6 percent between 2000 and 
2040. The difference is likely due to a more modest benefit adjustment in the Ministry's calculations, which links to civil service wages assumed to grow less than $2 \frac{1}{2}$ percent annually. In contrast, the calculations at hand assume civil service wages to grow in lockstep with wages in the private sector, around $3 \frac{1}{4}$ percent a year. Indeed, an annual wage growth differential of over $3 / 4$ percent would reduce relative civil service wages by some 30 percent over the projection period. Werding and Blau (2001) put the expenditure increase between 2000 and 2050 at 0.7 percent of GDP. But they exclude the supplementary schemes and their calculations predate the 2001 civil service pension reform. The Sachverständigenrat (2001) also draws attention to the future fiscal burden associated with civil service pension obligations.

\section{Health care expenditure}

140. Public health care expenditure, excluding outlays for long-term care for the elderly, are projected to increase relative to GDP by 1.3 percentage points, to 8.6 percent in 2050 from 7.3 percent in 2001 . The increase takes place very gradually throughout the entire projection period. Germany's sickness funds, which are part of the social. security system, account for most of the spending, but direct budgetary outlays for hospital investment, prevention, and health care of civil servants are also important. Moreover, some health care expenditure is borne by the pension fund for measures to rehabilitate the disabled. The projections cut across all these categories.

\section{The impact of population aging on health care expenditure has been debated} extensively in health economics. While the age profile of per capita health care expenditure rises steeply with age (Table IV -4) in all countries, cross-country and panel-data regressions usually fail to find explanatory power in age-related variables (Gerdtham and Jönsson, 2000). Microstudies establish that health care expenditure tends to be bighly skewed toward the final years of patients' lives (Zweifel et al., 1999). This helped forge the consensus that a good part of health care expenditure is related primarily to "closeness to death" rather than calendar age. This is good news for advanced economies where aging is driven to a large extent by rising live expectancy. In such circumstances deaths per thousand of population rise more slowly than the population share of those aged 65 and above (Figure IV-6).

142. The approach followed here tries to adequately capture the impact of the shifting demographic composition by accounting for the closeness-to-death effect as well as the calendar-age effect. In a first step, it regresses age-group specific survival probabilities, calendar age, and a dummy variable for the first year of life on agengroup specific health care expenditure. The following specification explains over 96 percent of the variation of age-group specific health care expenditure: 


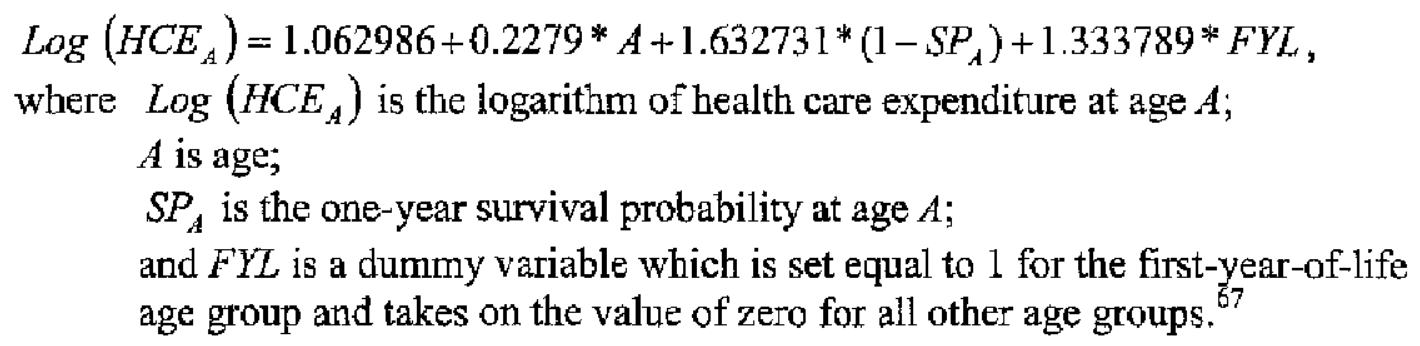

In a second step, the above parameters are used to project forward bealth care expenditure using the projected average age of the population and population-wide survival and bith rates. According to this approach, the demographic composition effects raises health care costs by 18.5 percent over the next 50 years. The increase would have been significantly larger, 28 percent, if health care expenditure had simply been projected by applying the existing age profile of health care expenditure to the future age composition of the population.

Table IV-4. Selected OECD Countries: Health Expenditure By Age Group 1/

\begin{tabular}{|c|c|c|}
\hline & pop, 65 t/pop 0-64 & pop. $75+/$ pop 0-64 \\
\hline Canada & 5.6 & 8.1 \\
\hline Japan & 4.9 & 5.7 \\
\hline United States & 4.6 & 6.4 \\
\hline New Zealand & 4.3 & 6.4 \\
\hline Australia & 4,1 & 5.9 \\
\hline Finfand & 4.0 & 5.5 \\
\hline Stwitzerland & 4.0 & 5.7 \\
\hline United Kingdom & 3.4 & 4.6 \\
\hline France & 3.0 & 3.7 \\
\hline Czech Republic & 2.8 & 3.0 \\
\hline Sweden & 2.8 & 3.4 \\
\hline Germany & 2.7 & 3.2 \\
\hline Korea & 2.4 & $\ldots$ \\
\hline Portugal & 1.7 & $\ldots$ \\
\hline Average & 3.6 & 5.1 \\
\hline
\end{tabular}

${ }^{67}$ Data on age-group specific health care expenditure refer to expenditure by sickness fundis and is compiled by the Federal Insurance Office (Bundesversicherungsamt) for purposes of risk equalization between competing sickness funds (Risikostrukturausgleich). Survival probabilities calculate from population statistics of the Federal Statistical Office on deaths by age and age-group sizes. 
Figure IV-6. Germany: Demogra phic Indicators, 2000-50

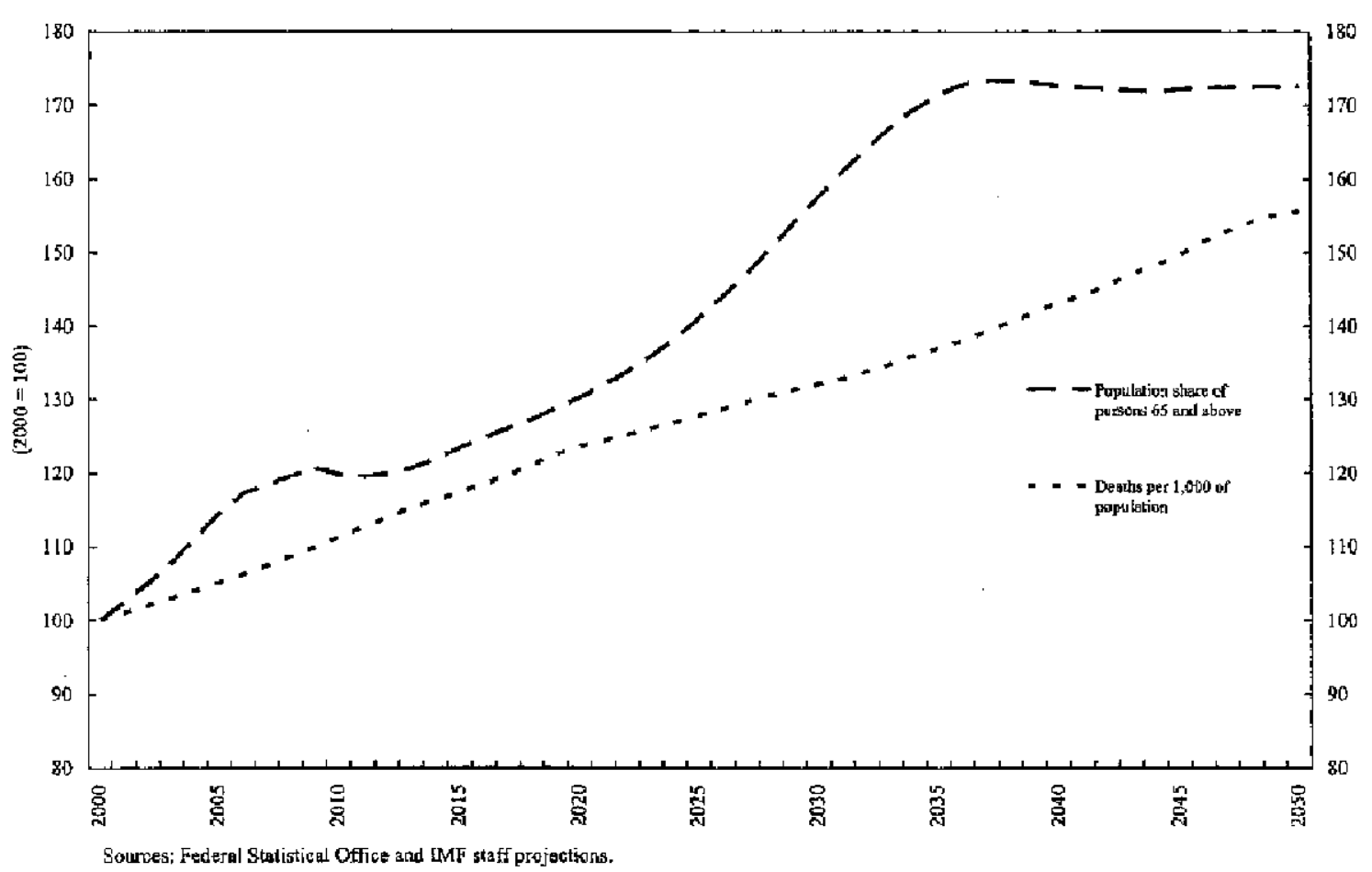

143. There are several factors that might give rise to an underestimation of future health expenditure costs, but they are all unrelated to population aging. Accordingly, other studies typically project a larger increase of health care expenditure. The Economic Policy Committee reckons that health care expenditure will rise between 1.4 and 2.1 percent of GDP through 2050. The final report of the Enquête Commission of Germany's lower house of parliament (2002) provides a comprehensive list of papers that project health care expenditure for Germany. They exhibit an enormous variety of results, with the required increase of the contribution rate ranging from as low as 2 percentage points to has high as 20 percentage points, from 14 percent currently. Cost-pushing factors that are not taken into account here include:

- technological progress in medicine. While advances in medical technology could in principle be cost reducing as well as cost increasing, in practice they seemed to have been mostly of the latter variety in recent decades. Few would doubt that the wider diffusion of technological advanced invasive treatments has contributed to rising health care costs. In particular, it has been argued that technological progress is responsible for the steepening of the age profile of health care expenditure that has been observed in Germany (Ulrich, 2000);

- an income elasticity of health care demand greater than one. The income elasticity of heaith care demand is another much researched topic in health economics. In cross country data, GDP is generally found to be the single most 
important determinant of the health care expenditure ratio. This observation led early research to conclude that the income elasticity exceeded one and that health care was therefore a "luxury good" (Newhouse, 1977). More sophisticated subsequent analysis revealed, however, that previous estimation techniques suffered from omitted variable bias, and that income elasticity was around one when properly estimated (Gerdtham and Jönsson, 1992). But a few recent studies continue to put income elasticity significantly above one (Roberts, 1998). Had the calculations here used an income elasticity of 1.1 instead of one, the increase of health care expenditure over the next fifty years would have been much higher ( 2.7 percent of GDP rather than 1.3 percent of GDP);

- a steepening of the age profile of health care expenditure. Germany's profile appears significantly flatter than in comparable other countries. For example, countries such as Canada and Switzerland both allocate a much larger portion of their health spending toward the elderly (Figure IV-7). If Germany had the spending age profile of these countries, the projected increase of health care expenditure due to aging would be twice as great. It is not quite clear why Germany's age profile looks so relatively benign. It cannot be ruled out that Germany's profile is simply a data fallacy, e.g., other countries might include expenditure for long-term care while Germany is not. But it is also possible that Germany's profile is bound to adjust to the one of most other countries over time.

Figure IV-7, Germany, Canadn, Switzerland: Per Capita Health Expenditure by Age Group

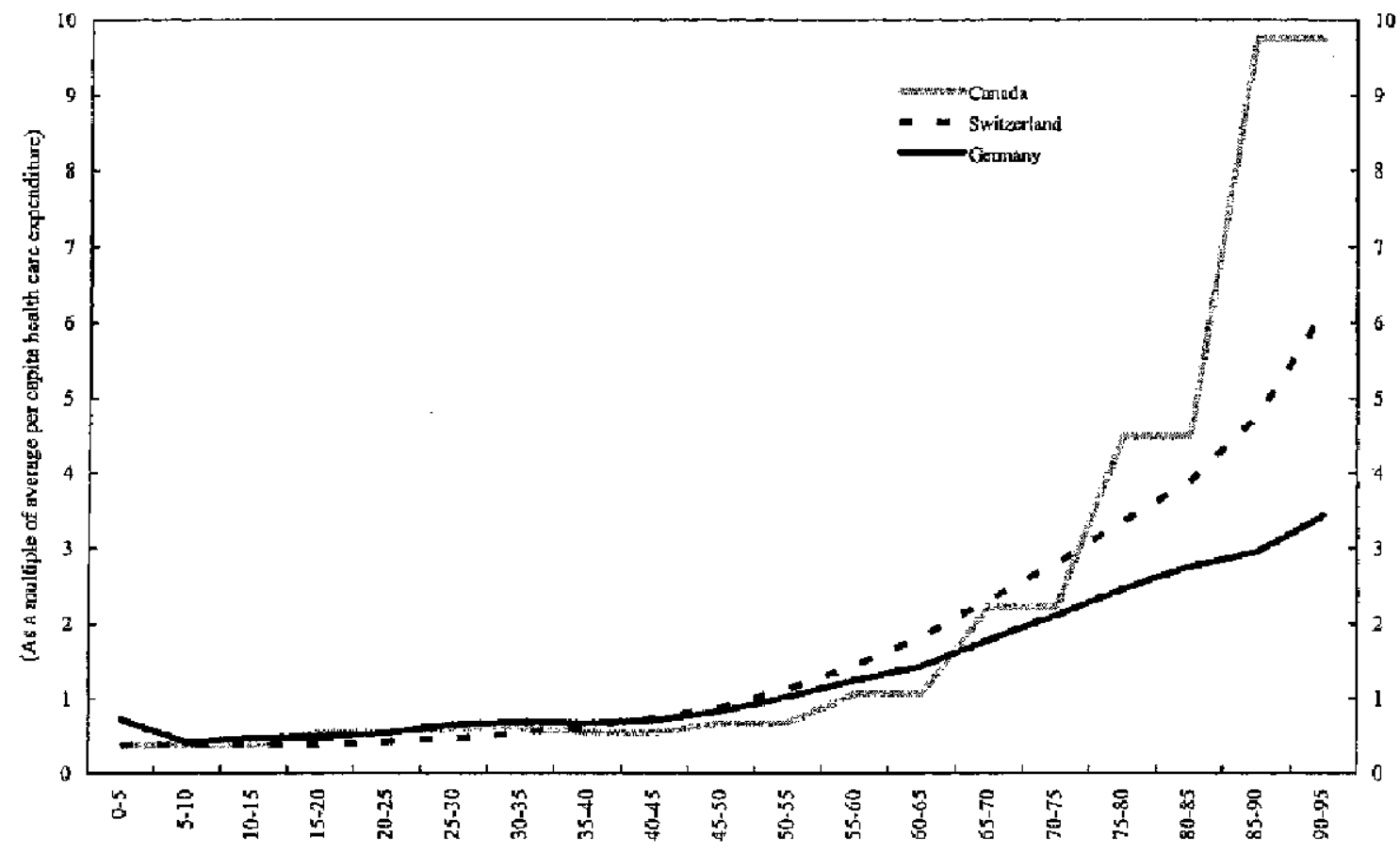

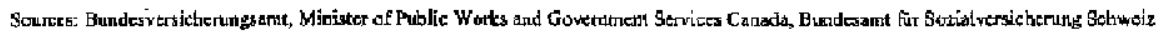




\section{Long-term care insurance}

144. Public expenditure on long-term care for the elderly is projected to increase relative to GDP by 0.7 percentage points, from 0.9 percent now to 1.5 percent in 2050 . The increase takes place gradually throughout the projection period. Long-term care insurance, which is part of the German social security system, accounts for most of the spending. Some additional spending is footed through social assistance, primarily for the needy in nursing homes.

145. The main factors considered in the projections are the morbidity of the population and the availability of informal care provided by family members. Morbidity is assumed to depend on "closeness to death" rather than calender age. In other words, increasing longevity is taken to mean that people will be able to enjoy more disability-free years in the future, rather than merely more years in need of care.

146. The pool of potentlal informal caregivers is bound to shrink. Currently almost 60 percent of the care supported by the long-tern care insurance is provided by family members and friends. A large part of these caregivers are children or children-in-law of those in need of care. Declining fertility as well as rising labor force participation of women will limit the scope of such arrangements in the future. Consistent with population and labor force participation projections it is estimated that the share of informal care will decline to 37 percent from 57 percent at present. Informal as well as formal care is covered by the longterm care insurance but formal care is more expensive. In line with the fee schedule of the long-term care insurance it is assumed here that formal care is twice as costly as informal care for cases with the same degree of disability. In the event, the shift toward more formal care raises long-tem care expenditure by close to 14 percent over the projection horizon.

147. The income elasticity of demand for long-term care is also set to unity. Although not much research has been done on this topic, it is appealing to use the same elasticity as in the case of health care. Moreover, unlike in the case of health care, there is a less direct link between demand and public expenditure. The public health care insurance generally covers all medically necessary treatment with no upper limit, so that an increase in demand automatically translates into a proportional increase of public health care expenditure. Not so in the case of the long-term care insurance, which covers expenses only up to a certain monetary limit, graduated according to the severity of the disability. So unless these monetary limits are periodically adjusted, public expenditure on long-term care rises less than proportionately with demand. Basing the calculations on a unitary elasticity assumption is equivalent to assuming that monetary limits are adjusted with per capita GDP and that demand elasticity is at least one.

148. Few studies have thus far attempted to project long-term care expenditure. Indeed, unlike for many other countries, Germany has still to provide its projection in the context of the Economic Policy Committee and OECD aging exercises. Diez (2001), the DFW-Institute (2001), and Rothemberg (2001) have undertaken to project the number of 
long-term cases though. Estimates range from a 40 percent to a 210 percent increase. This compares to 77 percent increase of the expenditure ratio here.

\section{Remaining aspects of public finances}

149. Projections of all remaining budgetary items are kept as simple as possible for the years after 2007. All revenue grows at the same rate as nominal GDP, except for social security contributions which also reflect scheduled increases of pension contribution rates (from 19.1 percent currently to 22 percent in 203 I). Likewise, other expenditure generally grows with nominal GDP. However, the 2008 and 2009 installments of the subsidy for second-pillar pension contributions are factored in separately, costing 0.1 percent of GDP. Moreover, unemployment related expenditure (excluding pension and health care contributions paid by the unemployment fund) also depends on the number of unemployed. The interest bill is determined endogenously as the product of average public debt and the implicit interest rate, which is assumed constant from 2001. Finally, child-related expenditure in the form of child allowances and spending on primary and secondary education, is linked to the number of the under 25-year olds.

150. Projections for the period 2002 to 2007 are consistent, in the stability program scenario, with IMF staff's current understanding of government policy intensions. They incorporate strong fiscal consolidation. The budget balance improves by over 2 percent of GDP, despite net tax cuts and second-pillar pension fund subsidies worth about 1 percent of GDP. Some $3 / 4$ points of the improvement are probably due to cyclical factors. 
Germany: Expenditure of Public Pension Fund (GRV), 2000-2050

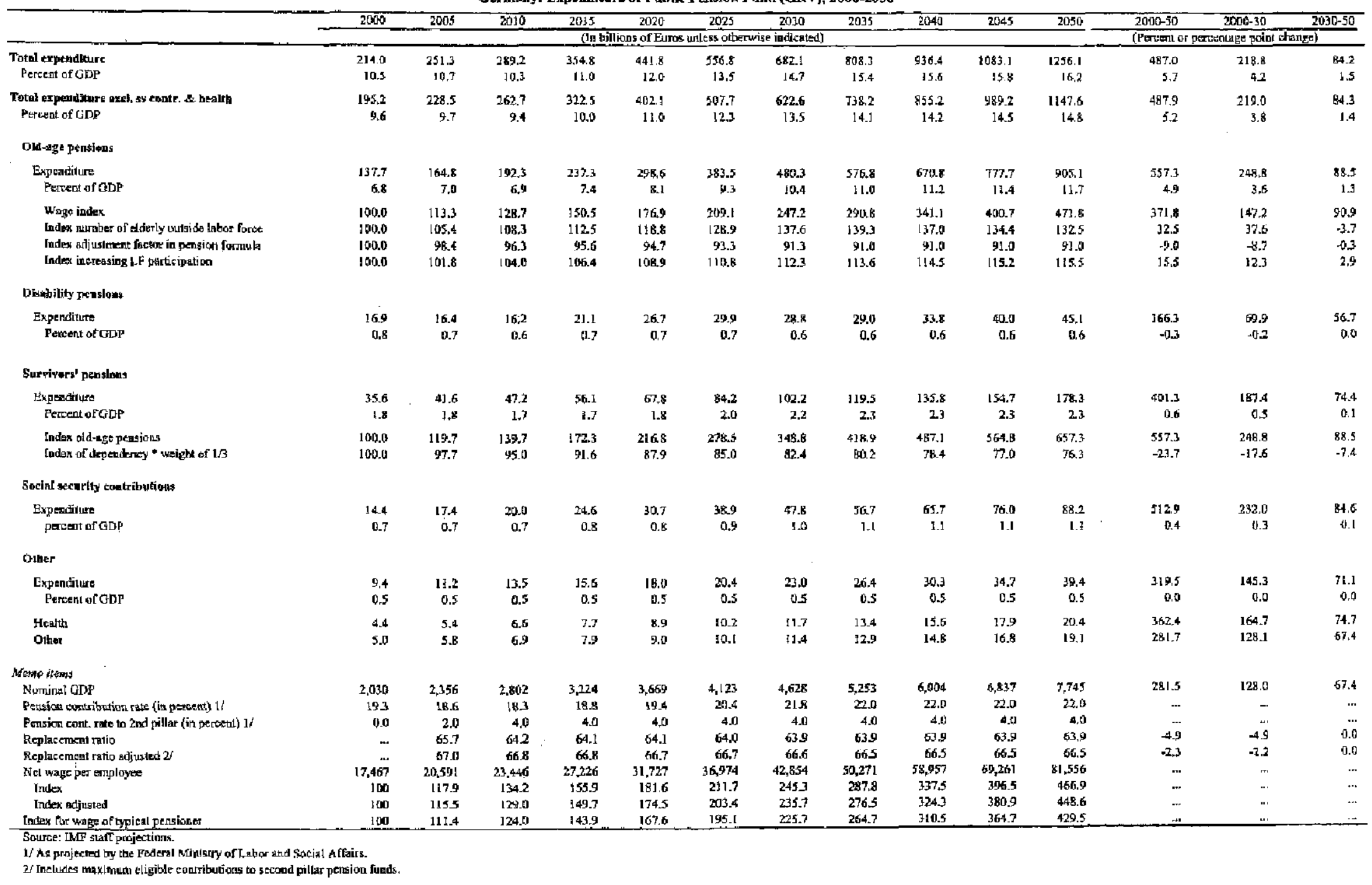


Germany: Expenditure for Clvil Service Pensions, 2000-2050

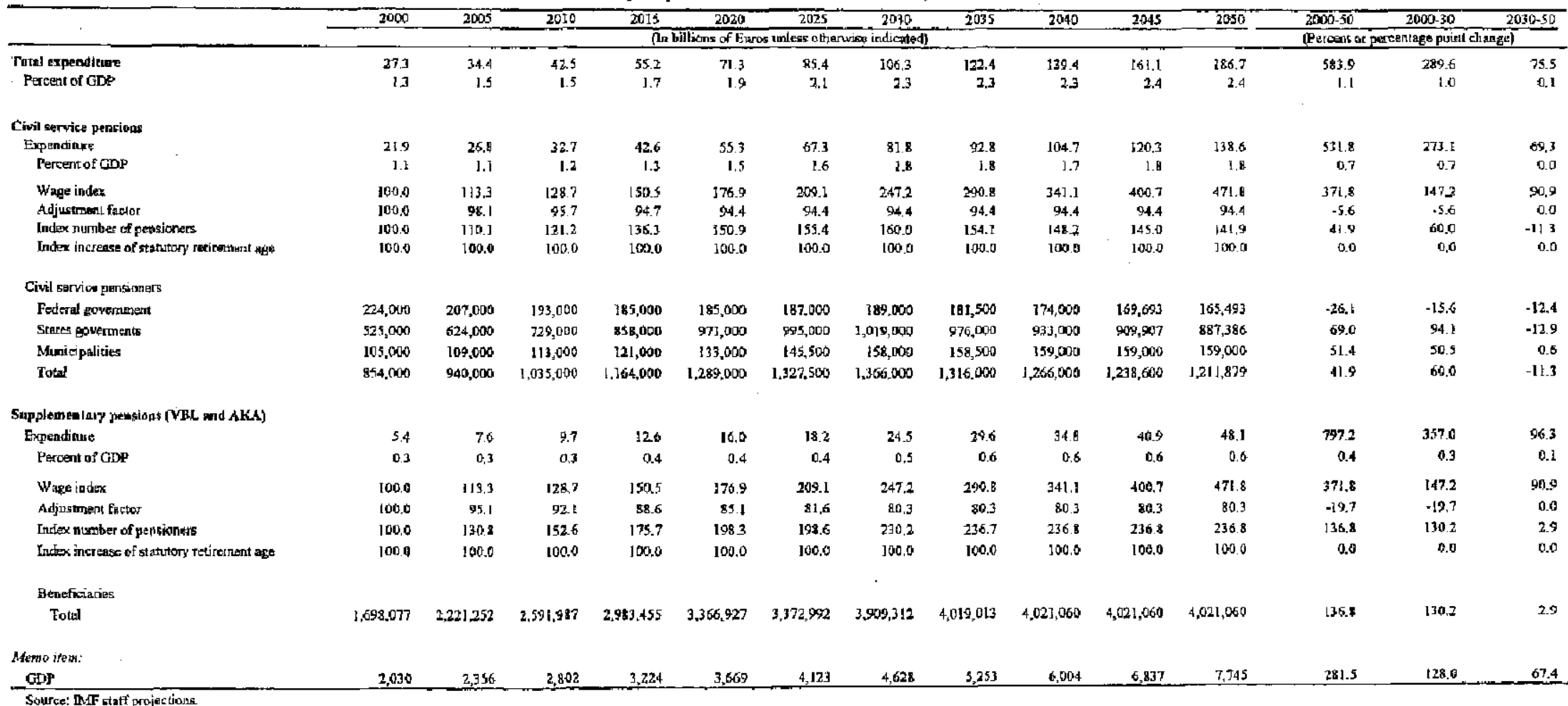


Germany: Health Care Expendi mure, 2000-1050

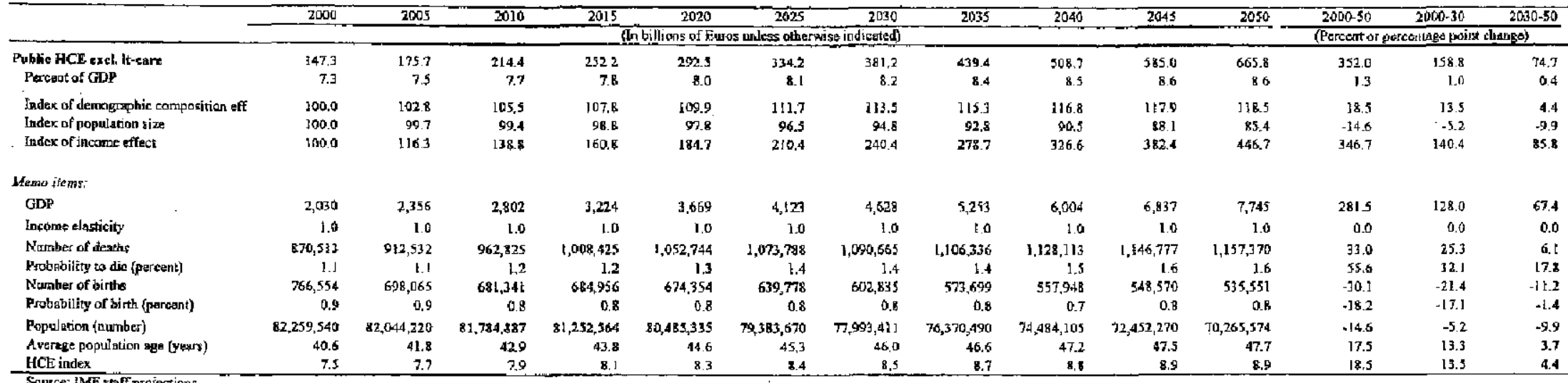

Germany: Long-Term Care Bxpenditure, 2000-2050

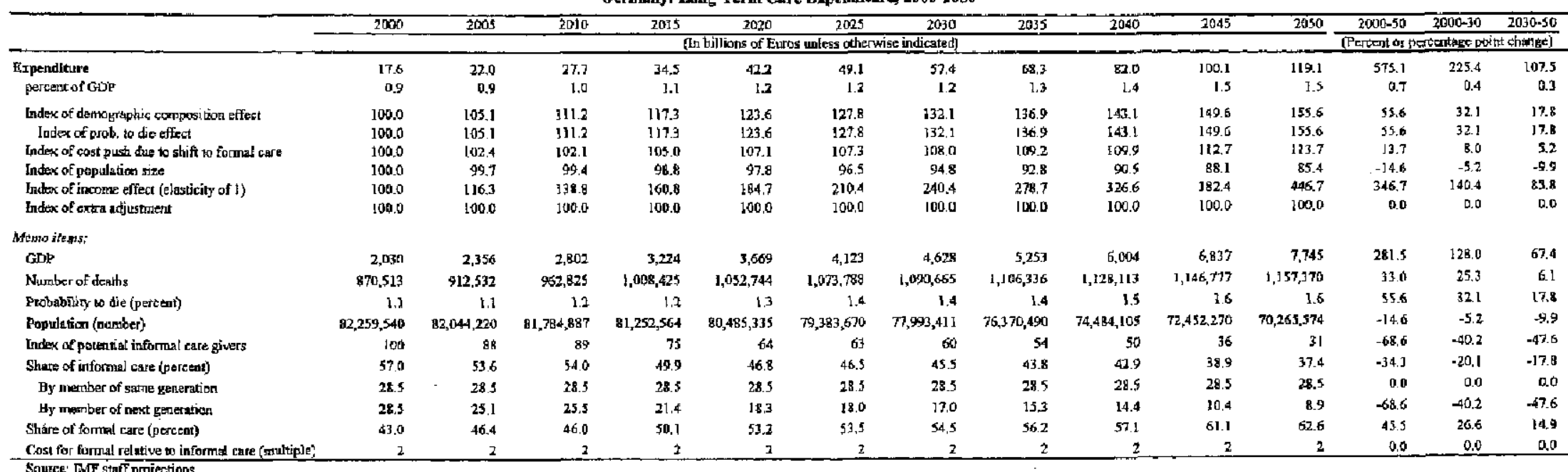




\section{References}

Carey, David and Josette Rabesona (2002), "Average Effective Tax Rates on Capital, Labor and Consumption," presented to The CESifo Summer Institute, Venice, July 2002, forthcoming as OECD Working Paper.

Dang, Thai Than, Pablo Antolin and Howard Oxley (2001), "Fiscal Implications of Aging: Projections of Age-Related Spending," ECO/WKP(2001)/31, OECD.

Enquête Commission of Germany's Lower House of Parliament (2002), "Demographischer Wandel - Herausforderungen unserer älter werdenden Gesellschaft an den Einzelnen und die Politik," Bundestags Drucksache 14/8000.

Gerdtham, Ulf-G. and Bengt Jönsson (1992), "International Comparisons of Health Care Expenditure: Conversion Factor Instability, Heteroscedasticity, Outliers and Robust Estimators," Sournal of Health Economics No. 10.

Gerdtham, Ulf-G. and Bengt Jönsson (2000), "International Comparisons of Health Expenditure: Theory, Data and Econometric Analysis," in: Handbook of Health Economic, Volume 1, edited by A.J. Culyer and J.P. Newhouse.

Gruber, Jonathan and David Wise (2001), "An International Perspective on Policies for an Aging Society," NBER Working Paper 8103.

DTW (2001), "Wochenbericht des DTW," No 68/5.

Dietz, B. (2001), "Kosten steigen schneller als erwartet. Entwicklung des Pflegebedarfs bis 2050 ," Soziale Sicherheit, No. 1.

Economic Policy Committee (2001), "Budgetary Challenges Posed by Aging Societies," ECP/ECFTN/655/01.

European Commission (2001), "The EU Economy - 2001 Review," European Economy No. 73 .

Federal Ministry of Finance (2000), "Guiding Principles of Fiscal Policy," Berlin.

International Monetary Fund (2000), "Germany: Selected Issues," IMF Staff Country Report No. 00/142 (Washington: International Monetary Fund).

Manzke, Bernhard (2002), "Zur Tragfähigkeit der öffentlichen Haushalte in Deutschland eine Analyse anhand der Generationenbilanzierung," Diskussionspapier 10/02, Deutsche Bundesbank. 
Merrik, Thomas W. (2002), "Population and Poverty: New Views on an Old Controversy," International Family Planning Perspectives, Volume 28, Number 1, March 2002.

Newhouse, J.P. (1977), "Medical Care Expenditure: a Cross-national Survey," Journal of Human Resources No. 12.

Bundesministerium der Inneren (2001), "Daten und Schlussfolgerungen zum Zweiten Versorgungsbericht der Bundesregierung. Das Wichtigste in Kürze," Berlin, September 2001.

Pfeiffer, Ulrich (1999), "Deutschland - Entwicklungspolitik fir ein entwickeltes Land," Europäische Verlagsanstalt/Rothbuch Verlag, Hamburg.

Roberts (1998), "Sensitivity of Elasticity Estimates for OECD Health Care Spending: Analysis of a Dynamic Heterogeneous Data Field“ “, Paper prepared for the Seventh European Workshop of Econometrics and Health Economics, STAKES, Helsinki, Finland, September 1998.

Rothemberg, H. (2001), "Finanzwirtschaftliche und strukturelle Entwicklungen in der Pflegeversicherung bis 2040 und mögliche alternative Konzepte," Endbericht zu einer Expertise für die Enquête-Kommission.

Rother, P.C., M. Catenaro, and G. Schwab (2002), "Aging and Pensions in the Euro Area, Selective Survey and Simulation Results," ECB mimeo.

Sachverständigenrat zur Begutachtung der gesamtwirtschaftlichen Entwicklung (2001), "Für Stetigkeit - Gegen Aktionismus," Jahresgutachten 2001/02.

Stephan, Anette (2002a), "Neuordnung der betrieblichen Altersversorgung im öffentlichen Dienst - Teil 1,“"ZTR 2/2002.

Stephan, Anette (2002b), "Neuordnung der betrieblichen Altersversorgung im öffentlichen Dienst - Teil 2,"ZTR 4/2002.

Ulrich, Volker (2000), "Medizinisch-technischer Fortschritt, demographische Alterung und Wachstum der Gesundheitsausgaben: Was sind die treibenden Faktoren?," Gesundheitsökonomie \& Gesundheitsmanagement, 5, 2000.

Werding, Martin and Harald Blau (2001), "Auswirkungen des demographischen Wandels auf die offentlichen Finanzen: Modellrechnungen fur die staatlichen Alterssicherungssysteme," ifo Institut für Wirtschaftsforschung, München, October 2001.

Zweifel, Peter, Stefan Felderer, and Markus Meiers (1999), "Aging of Population and Health Care Expenditure: A Red Herring?," Health Economics No 8. 
Zypries, Brigitte (2002), "Statement aus Anlass der öffentlichen Anhörung des Haushaltsund Finanzausschusses des Landtags Nordrhein-Westfalen zum Thema: "Sicherung der Versorgung des öffentlichen Dienstes - Möglichkeiten zur Senkung der Versorgungsleistungen" am 18. April 2002."

(CInternational Monetary Fund. Not for Redistribution 


\section{Y. Health Care Reform lN Germany ${ }^{68}$}

\section{A. Introduction}

151. Germany's health care system has come under increasing criticism in recent years for its high and rising costs and disappointing health outcomes. Cost pressures are likely to intensify with population aging and the diffusion of highly sopłisticated treatments to an increasing number of patients. Public spending on health care is comparable in size with outlays for pensions. And, as it is predominantly financed through payroll taxes, health policy has significant implications for the labor market. Reform proposals range from a plethora of minor changes to wholesale reorganization of the health care system. This chapter argues that higher patient co-payments with rebates for the use of efficient providers and prevention appear promising reform elements. Supplementary regulatory intervention might also be necessary.

\section{From a macroeconomic point of view there are three main concerns about health care:}

- Its large fiscal costs. Public health care spending currently amounts to 8 percent of GDP, the largest spending ratio in the world and the second largest government spending program after pensions.

- Its tax burden on labor. Payroll taxes, currently almost 16 percent of gross wages, finance the bulk of health care expenditure in Germany. Payroll taxes drive a wedge between labor costs and take-home pay. Employment suffers unless hikes of payroli taxes are fully compensated by commensurate reductions of take-home pay. A full offset is unlikely since generous social programs, the possibility of moon lightening, and the benefits of leisure all set a floor to take-home pay. In surveying the empirical literature Nickel and Layard (1999, p.3061) conclude "that overall labor tax rates do influence labor costs in the long run and hence raise unemployment."

- Its waste of resources. Health care makes up a significant sector of the economy, accounting for about one out of every nine jobs (Statistisches Bundesamt, 2002). Reports of waste abound. About half of all x-rays are performed unnecessarily, drugs worth some 0.1 percent of GDP are thrown out, almost 80 percent of knee arthroscopies are unwarranted, hospital stays are almost twice as long as in other countries, etc. (Public Health Insurance Fund, 2002). Non-negligible welfare gains could probably be reaped if these wasted resources were gainfully redeployed elsewhere.

153. Inadequate incentives for economical behavior are the root cause of excessive costs and waste. Pervasive insurance coverage gives rise to moral hazard on the part of

${ }^{68}$ Prepared by Christoph Klingen. 
patients. Since they essentially face a zero price for medical treatment they have an incentive to always demand the highest quality services without regard to cost and seek all treatment that could conceivably have beneficial effects. Providers have every reason to comply as they typically earn more when they render more services. Indeed, physicians might even exploit their professional authority and provide unwarranted treatment, perform useless tests, and discharge patients overly late from hospitals. This phenomenon is known as the problem of induced demand. Moreover, dynamic effects compound these static inefficiencies: the medical profession and the pharmaceutical industry have an incentive to develop ever more sophisticated treatments. As costs are not a consideration for patients, demand for such new treatments is always assured, even if they offer little medical advantages at vastly higher costs. On the other hand, incentives to develop new treatments that offer the same medical benefits as existing treatments at much lower costs are absent.

\section{Equity considerations and concerns about market failure are the traditional} arguments against organizing health care systems according to market principles. A market-based system without insurance would avoid the above inefficiencies, but is subject to a host of serious drawbacks. The poor might be unable to afford medical treatment, there would be no solidarity transfer from the healthy to the sick, and people would be exposed to large risk. A market-based system with insurance would be prone to many of the above inefficiencies. In addition, markets might make insurance premiums unaffordable for the poor and higher for the sick than for the healthy, thus compromising solidarity and protection from risk. Moreover, there is the more general concern that risk-selection seriously impairs the efficient operation of insurance markets (Rothschild and Stiglitz, 1976, Cutler, 1996, Luft, 1986, and Holahan, 1997).

\section{Inefficiencies become more of a concern as the capabilities of medicine expand.}

When modern health care systems were established, medical capabilities were limited, health care costs were low, and the health care sector was small. Under those circumstances inefficiencies could easily be tolerated. Writes Cutler (2002, p.881), "countries were content to have inefficient medical-care systems provided they treated all equally." With health care now having grown into a major industry this is no longer true.

\section{Inefficiencies can be redressed through regulation, reliance on incentives, or} both. During the 1980 s and 1990 s policy makers relied primarily on tightening regulation. While Germany did not go as far as some other countries, the mumber of physicians, drug prices, the budgets of hospitals and out-patient services, and the purchase of major medical equipment became subject to regulation. Disappointed with the results of more regulation, improving incentive structures has increasingly become the new mantra of international health care reform (Cutler, 2002).

\section{There are no easy answers to the rising burden of health care costs, but a few} measures nonetheless appear promising. Virtually all advanced economies are grappling with health care reform and blueprints for optimal health care systems do not exist. Moreover, system design requires value judgments and raises fundamental ethical questions if state-of-the-art medical treatment is simply becoming too expensive to be made available to every member of society. Nonetheless, the case for mobilizing efficiency reserves is clear. 
There is a growing consensus that the introduction of meaningful co-payments should be part of this mobilization effort, although the government is currently not prepared to go down this route. When designed properly, they would strengthen economical consumer behavior and foster competition among providers, while not undermining solidarity. Co-payments are no panacea, however, and might need to be supplemented with regulatory reform elements. Flexible global budgets for health care expenditure might be an option and so is government support for cost-reducing medical innovation.

\section{B. The German Health Care System ${ }^{69}$}

\section{A brief description of the German health care system shows that incentives for} economical behavior are missing and points to overall inefficiencies with particular failings in non-core health care expenditure, in-patient services, and prevention and health promotion. Universal insurance coverage, generous benefits, free access, and modest co-payments compound to ideal conditions for high health care demand. Fee-for-service remuneration of providers along with lack of competition among them are conducive to ample supply. The large resources that are consequently devoted to health care do not, however, translate into a particularly favorable population health. This might partly reflect too little emphasis on prevention and health promotion. Other inefficiencies appear to be mostly across-the-board. There is tentative evidence, however, that medical spending outside the main categories is a particular problem. Moreover, above-average hospital utilization rates combined with below-average hospital spending shares might indicate that hospital budgets have compressed outlays but not dealt sufficiently with excessive hospital stays.

159. The German health care system follows the social insurance model. Generally, all gainfully employed as well as other defined groups such as pensioners, students, and the unemployed are legally required to be insured against sickness under the public health insurance. Under certain conditions one can opt out and purchase private health insurance instead. Public health insurance is financed through payroll taxes and coverage extends to dependents at no extra charge. Out-patient care is provided by private physicians and inpatient care by a mix of private and public hospitals. Legislation in the area of health care is generally the joint responsibility of federal and state governments with oversight of its proper implementation resting with the federal government for issues that concern Germany as a whole and with state governments otherwise. State governments are also in charge of prevention, medical education, and hospital planning and investment. Corporatist bodies such as doctors' associations, health insurance associations, and doctor-insurance committees negotiate fee schedules, allocate global budgets, regulate the number of doctors by region, and determine the details of coverage under the public health insurance.

160. Virtually the entire German population has health insurance. Some 88 percent is covered by public health insurance, which comprises some 420 different funds, each servicing either a geographical region, an occupational group, or employees of specific

${ }^{69}$ This section draws on Busse (2000) and Busse (2002). 
companies. They offer similar benefits, but contribution rates may differ. Private health insurance covers another 9 percent of the population. Employees with incomes above $€ 3,375$ per month can opt out of public health insurance and purchase policies for themselves and their dependents from one of about 50 private health insurers instead. Civil servants and judges receive partial insurance coverage from the government and typically purchase supplementary private insurance. Soldiers, police officers, and recipients of social assistance benefit from free government health care and account for another 2 percent of the population.

161. Generally, public health insurance covers all medically necessary treatments, access to health care services is free of restrictions, and co-payments are moderate. Exclusions of treatments are possible but rare in practice. Most drugs become reimbursable upon approval. Public health insurance also extends to dental coverage, but excluding treatment for purely cosmetical purposes. Benefits are typically provided in kind. Providers are reimbursed by insurance funds and bill patients only for co-payments, if any. For the first 14 days of a hospital stay patients have to pay $€ 9$ per day out-of-pocket. Co-payments for drugs vary between $€ 4$ and $€ 5$, depending on pack size. Non-physician care, dental crowns, and dentures require higher co-payments. There is no annual deductible and co-payments are waved for low-income families and capped for all others.

\section{Remuneration of providers traditionally follows the fee-for-service model but} the use of budgets has gained ground in recent times. In out-patient care, public health insurance funds and doctors' associations set overall budgets which are allocated across individual physicians in proportion to the services they provide. To guard against excessive treatment, random checks tally per-patient services of individual doctors against averages and doctors are required to explain above-average provision of services. Under the system of "dual hospital financing," in-patient facilities receive investment financing from state governments and health insurance reimbursements cover operating expenses.

Reimbursements are a combination of per-diems, procedure case fees, and prospective fees, but total reimbursements are also subject to target budgets for each individual hospital.

Overruns reduce reimbursements by $50-90$ percent. Hospitals are allowed to retain 40 percent of savings. A new system where reimbursements depend only on the so-called Diagnosis Related Groups (DRGs) of treated cases, is planned for introduction during 2003-07. As to pharnnaceuticals, target budgets now apply at the level of individual physicians, after attempts to introduce more stringent budgeting had failed repeatedly. Regulations fix wholesale and retail margins for drugs. Ex-factory prices of drugs responsible for about 65 percent of pharmaceutical expenditure are subject to fixed reimbursement limits. Limits are set at the lower $33^{\text {rd }}$ percentile of prices for comparable drugs. In addition, physicians are encouraged to prescribe active ingredients of drugs rather than brand names to allow pharmacists to pick the cheapest drug. In private health insurance, remuneration of providers is on a fee-for-service basis.

163. Organization of health care providers is a private-public mix. Physicians in private office, typically organized as a single-doctor practice, operate on a for-profit basis. They are overseen by doctors' associations, which guarantee availability of appropriate medical services throughout Germany in exchange for the monopoly to render out-patient services. The associations also regulate the number of physicians by region. Cirrently, only 
20 percent of regions are open for new doctors (of all fields of specialization) to set up practice (Bundesanstalt für Arbeit, 2002). Hospitals are mostly either publicly-owned or operate on a not-for-profit basis. For-profit hospitals account for 7 percent of hospital beds. The pharmaceutical industry is highly developed with about 1,100 for-profit companies, making Germany one of the leading drug-exporting countries. Pharmacies are for-profit, but highly regulated. There is currently no restriction on setting up new pharmacies, but margins are set by regulation and chain pharmacies as well as drug-distribution by mail are illegal.

164. Competition among insurance funds is increasingly being embraced. Since 1996 the insured have been free to choose between public health insurers, that are legally obligated to contract with any applicant. A government-operated risk equalization scheme compensates insurance funds with bad risks, and taxes insurance funds with good risks. The size of the transfer depends on the age, sex, and income composition of the insured, as a rough approximation of their morbidity, but refinements are in train. Private health insurance funds compete for members and generally charge risk-based premiums. They can reject applicants because of medical risk. Premiums are written on a level-lifetime basis, i.e., they are set for life at the time of application, taking into account age, sex, and current health status, witb a view of accumulating enough reserves when the insured is young to cover anticipated greater health care expenses in old age (Jost, 2001). Reserves are not portable between insurances making it unattractive for policy holders who are old or in bad health to switch insurers.

\section{Insurers' ability to select efficient providers remains narrowly circumscribed.}

Public health insurance funds continue to contract with providers as a group through doctors" associations. The insured retain free access to all physicians and their choice remains unencumbered by financial considerations. Competitive pressure on insurance funds thus cannot translate into pressure on providers to improve efficiency. In the case of in-patient care, insurers contract collectively with individual hospitals and patients are free in their choice of hospital. Again, without the possibility to contract selectively with efficient hospitals, or steer their patients to such hospitals, health insurance funds cannot compete on the basis of arranging for more efficient in-patient services.

166. Public health insurance finances the bulk of health care expenditure. In 2000 , it was responsible for 57 percent of health care expenditure, followed by private households (12 percent) and private health insurance funds ( 8 percent), (Figure V-1). Only a fraction of outlays by private households relates to co-payments and medical services/goods not covered by insurance though. This category also includes, for example, estimated time costs for the private care of elderly family members. Co-payments under the public health insurance accounted for less than a third of private households' health care expenditure in 1996 (Statistisches Bundesamt, 1998). 
Figure V-1. Germany: Health Care Expenditure by Sponsoring Agency, 2000 (Share of total in percent)

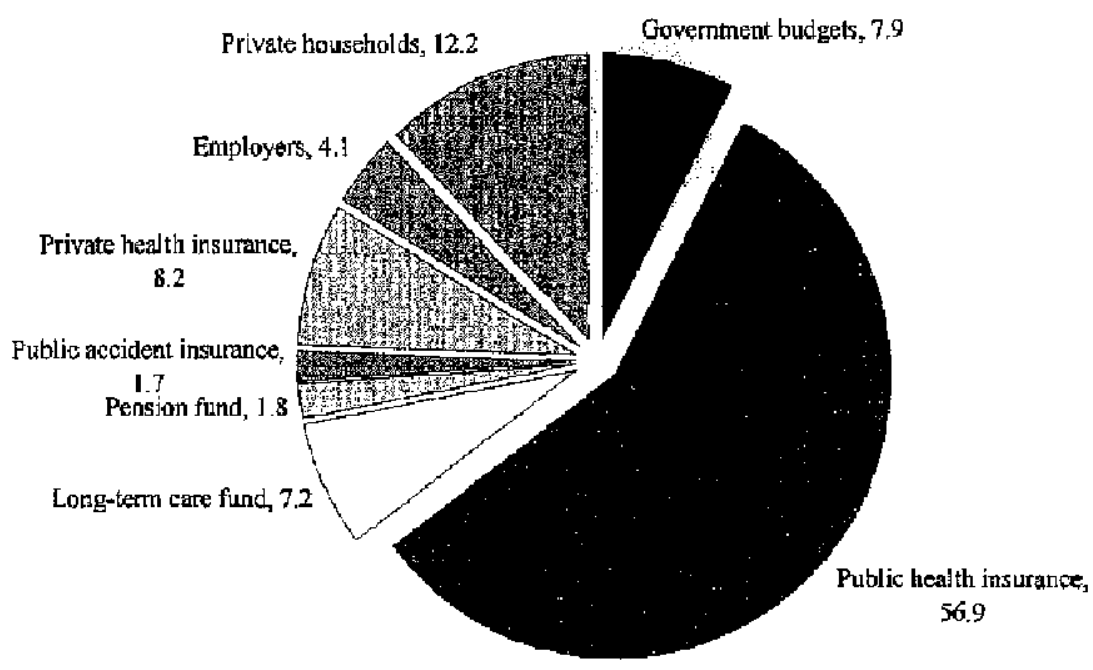

Source: Statistisches Bundesamt, Gesundheitsherichterstattung des Bundes 2000.

167. Social security contribution rates for public health insurance have been rising relentlessly and are beginning to rival contribution rates for public pensions. In 2002, average statutory contribution rates reached 14 percent compared to 12.4 percent in 1991 and 8.2 percent in 1970 (Figure V-2). On top of this, contribution rates for the long-term care insurance for the elderly, introduced in 1995, are 1.7 percent. Rates apply to employees' gross wages up to a ceiling ( $€ 3,375$ per month in 2002). Total contribution rates of 15.7 percentage points are not far behind the 19.1 percent rate financing pensions.

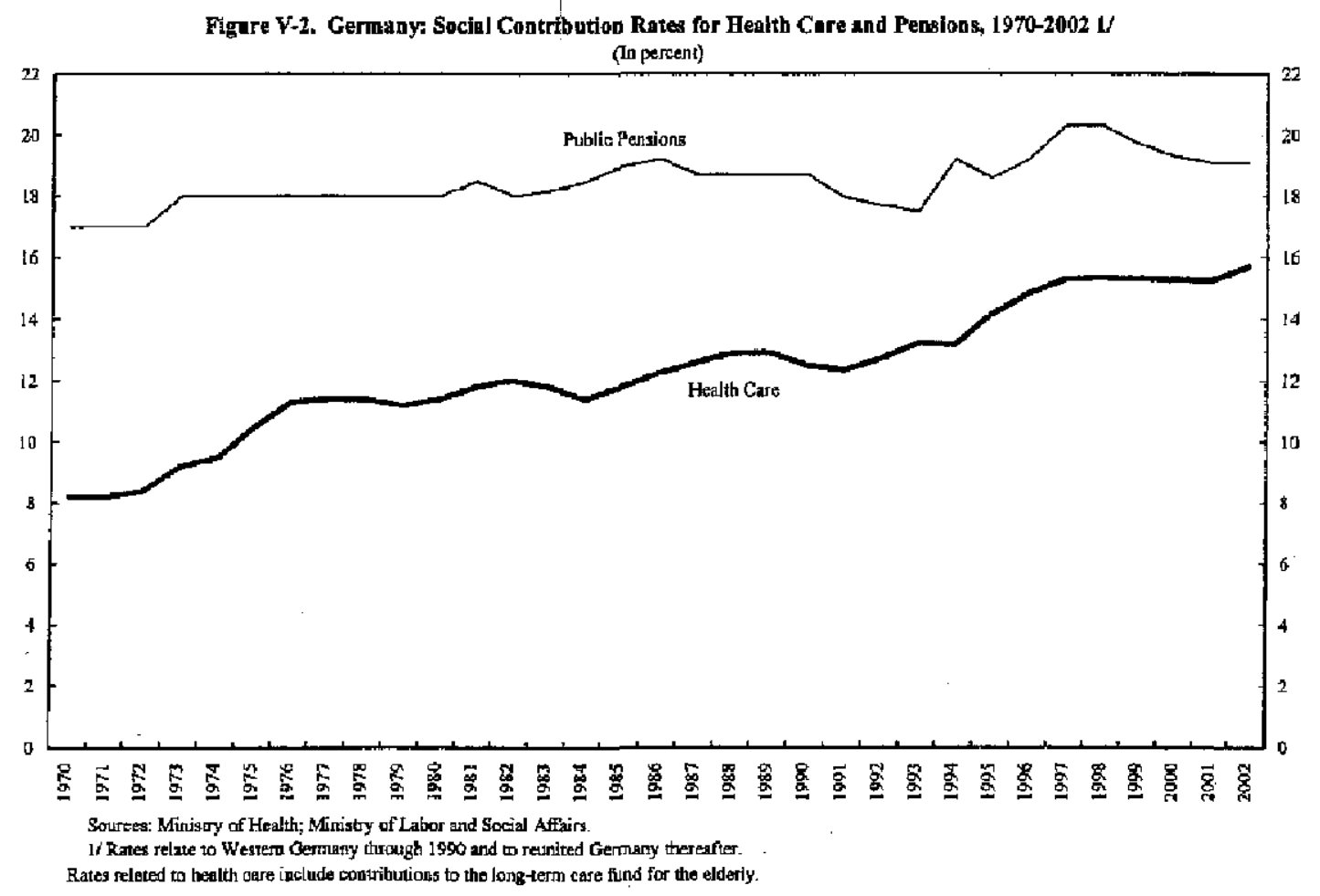

CInternational Monetary Fund. Not for Redistribution 
168. Public health care expenditure is higher in Germany than in any other country and total health care expenditure is among the highest in the world (Table V-1). Public bealth care expenditure amounted to 8 percent of GDP in 2000, compared to 5.7 percent of GDP for selected OECD countries, making health care the second largest public spending program in Germany after pensions. Total health care expenditure, i.e., if private spending is also taken into account, comes to 10.6 percent of GDP. This is about the same spending ratio as in Switzerland and is surpassed only by the United States, which spend 13 percent of GDP. However, health care expenditure is financed in a less distortionary way in these countries: Switzerland relies to a large extent on lump-sum per capita contributions and the United States rely on private financing.

Table V-1. Selected OLCD Countriea: Health Care Expendlture, 1970-2000

\begin{tabular}{|c|c|c|c|c|c|c|c|c|c|c|c|}
\hline \multicolumn{6}{|c|}{ Total Healits Care Expenditure } & \multicolumn{6}{|c|}{ Public Health Care Expenditure } \\
\hline & 1970 & 1980 & 1990 & 2000 & $1970-90$ & & 1970 & 1980 & 1990 & $20 \pm 0$ & $1970-90$ \\
\hline \multicolumn{7}{|c|}{ (2r petcent of GDP) } & \multicolumn{5}{|c|}{ (In pereent of GDP) } \\
\hline United States & 6.9 & 8.7 & 11.9 & 13.0 & 6.] & Germany & 4.6 & 6.9 & 6.7 & 8.0 & 3.4 \\
\hline Suritzerland & 5.60 & 7.6 & 8.5 & 10.7 & 3.1 & Ieeiand & 4.0 & 5.4 & 6.8 & 7.5 & 3.5 \\
\hline Germany & 6.3 & g.8 & $\mathbf{8 . 7}$ & 10,6 & 4.3 & Frajce & ... & ... & 6.6 & 7,2 & $\ldots$ \\
\hline France & $\ldots$ & $\ldots$ & 8.6 & 9.5 & $\ldots$ & Sweden & 6.0 & 8.4 & 7.6 & $\ldots$ & $\ldots$ \\
\hline Sweden: & 6.9 & 9.1 & 8.5 & $\ldots$ & $\ldots$ & Dentanark & $\ldots$ & 8.0 & 7.0 & 6.8 & in. \\
\hline Carnada. & 7.0 & 7.1 & 9.0 & 9.1 & 2.3 & Norway & 4.0 & 5.9 & 6.4 & 6.7 & 2.7 \\
\hline keland & 4.9 & 6,1 & 7.9 & 8,9 & 4.0 & Canada & 4.9 & 5.4 & 6.7 & 6.5 & 1.6 \\
\hline Belgiturn & 4.0 & 6.4 & 7.4 & 8.7 & 4.7 & Bęlginm & $\ldots$ & $\cdots$ & $r$ & 6.2 & $\ldots$ \\
\hline Australia & $\ldots$ & 7.0 & T.8 & 8.3 & $\ldots$ & Now Zealend & 4.1 & 5.2 & 5.7 & 6.2 & 2.1 \\
\hline Deremert & $\ldots$ & 9.1 & 8.5 & 8.3 & $\ldots$ & Australin & $\ldots$ & 4.4 & 5.2 & 6.0 & $\ldots$ \\
\hline Portugal & 2,6 & 5.6 & 6.2 & 8.2 & 5.6 & Switzerland & 3.3 & 4.8 & 5.7 & 60 & 2.7 \\
\hline Italy & ... & $\ldots$ & 8.0 & 8.1 & $\ldots$ & Itrily & $\ldots$ & $\cdots$ & 6.4 & 5.9 & $\ldots$ \\
\hline Netherlands & s. & 7.5 & 8.0 & 8.1 & $\cdots$ & Japen & 3.1 & 4,6 & 4.6 & 5.9 & 28 \\
\hline Austria & 5.3 & 7.6 & 7.1 & 8.0 & 2.7 & Unuited Kinggdam & 3.9 & 5.0 & 5.0 & 5.9 & 7.0 \\
\hline New Zealand & 5.1 & 5.9 & 6.9 & 8.0 & 2.9 & Portugat & 6.6 & 3.5 & $4 . I$ & 5.8 & 4.2 \\
\hline Jopan & 4.5 & 6.4 & 5.9 & 7.8 & 3.3 & Uniled States & 2.5 & 3.6 & 4.7 & 5.8 & 3.3 \\
\hline Nadway & 4.4 & 7.0 & 7.8 & 7,8 & 3.4 & Austia & 3.3 & 5.2 & 5.2 & 5,6 & 2.3 \\
\hline Spain & 3.6 & 5.4 & 6.6 & 7.7 & 4.1 & Netherlands & $\ldots$ & 5.2 & 5,4 & 5.5 & $\ldots$ \\
\hline Ziriled Kingdort & 4.3 & 3.6 & 6.0 & 7.3 & 2.8 & Spain & 2.3 & 4.3 & 5.2 & 5.4 & 3.1 \\
\hline Jrelend & 5.1 & 8.4 & 6.6 & 6.7 & 1.6 & Ireilind & 4.2 & 6.8 & 4.8 & 5.1 & 0.9 \\
\hline Finland & 5,6 & 6.4 & 79 & 6.6 & 1.0 & Finland & 4.1 & 5.0 & 6.4 & 5.0 & 0.9 \\
\hline Average & 5.0 & 6.9 & 7.2 & 8.1 & 3.5 & Averzge & 3.5 & 5.1 & 5.3 & 5.7 & 2.5 \\
\hline
\end{tabular}

169. Health care expenditure is relatively high across the board. The shares of inpatient, out-patient, and drug spending are comparable with those observed in other OECD countries (Table V-2). However, the share of other spending is unusually high. This appears to be due to a combination of: (i) high administrative costs, accounting for some 6 percent of total health care expenditure, an even higher share than in the United States; (ii) above average expenditure on home care; and (iii) above average expenditure for therapeutical appliances.

170. Growth of health care spending slowed in the 1980s and 1990s, both in nominal and real terms, although growth rates continued to exceed those of GDP somewhat. In the last two decades expenditure growth came down to 4-5 percent per year in nominal terms and around 2 percent in real terms (Table V-3). The long-run expenditure trend was similar for in-patient treatment, out-patient services, and drugs. Mirroting the findings of the crosscountry comparison, other components, such as non-physician medical services and nonpharmaceutical medical goods, expanded above average. Health care inflation accounts for about half of the increase of the health care expenditure ratio over the last twenty years, but is 
much less pronounced than in other countries. Since 1980, health care prices grew some 0.6 percentage points faster (per year) than the GDP deflator. The wedge is below the OECD average and significantly below the 2.3 percentage points experienced in the United States.

\begin{tabular}{|c|c|c|c|c|}
\hline & $\begin{array}{l}\text { In-patient } \\
\text { services }\end{array}$ & $\begin{array}{c}\text { Outppatient } \\
\text { services }\end{array}$ & Dregs & Öhrs \\
\hline & \multicolumn{4}{|c|}{ (In percex of woth health care expendiase) } \\
\hline Ausfralia & 41.2 & 26.6 & 11.5 & 20.7 \\
\hline Austria & 43,4 & 29.7 & $\ldots$ & $\ldots$ \\
\hline BelgiนM & 34,9 & 34,4 & $\ldots$ & $\ldots$ \\
\hline Canada & 42.7 & 26.2 & 14.9 & 16.2 \\
\hline Denmark & 54.3 & 24.7 & $9 . \mathrm{l}$ & 12.6 \\
\hline Finland & 40.9 & 30.5 & 14,9 & 13.7 \\
\hline France & 44.4 & 22.8 & 18.7 & 14.1 \\
\hline Gerimariy & 33,9 & 24.1 & 12.5 & 24.5 \\
\hline Iceland & 55.2 & 12.8 & $\mathbf{1 5 . 9}$ & 6.1 \\
\hline Irei and & $\ldots$ & $\ldots$ & 9.6 & .. \\
\hline Italy & 42,0 & 30.4 & 22.1 & 5.5 \\
\hline Jipan & $34 . J$ & 37.3 & 18.7 & 10.0 \\
\hline Netherlands & 49.6 & 14.8 & 11.3 & 242 \\
\hline New Zealand & $\ldots$ & $\ldots$ & 14.4 & .- \\
\hline :Norway & $\ldots$ & $\ldots$ & 9.0 & $\ldots$ \\
\hline Poxtuxgal & $m$ & $\ldots$ & 23.5 & $\ldots$ \\
\hline Spain & 34.4 & 26.7 & 18.6 & 203 \\
\hline Sireden & $\ldots$ & $\ldots$ & 12.9 & $\ldots$ \\
\hline Switeerland & 44,5 & 27.2 & 10,3 & 18.0 \\
\hline Linited Kiagdom & $\ldots$ & $\ldots$ & 15.8 & $\ldots$ \\
\hline United States: & $4 ! .3$ & 324 & 10.5 & 15.9 \\
\hline Awerage & 424 & 27.7 & 14.4 & $\mathbf{1 5 . 5}$ \\
\hline
\end{tabular}

Table V-3, Cermany: Health Care Expenditure by Type, 1970-2000

\begin{tabular}{|c|c|c|c|c|c|c|c|c|}
\hline & \multicolumn{7}{|c|}{ Hoshth expendiure } & \multirow{3}{*}{$\begin{array}{c}\text { Menso trem: } \\
\text { GDP } \\
\text { deflator }\end{array}$} \\
\hline & \multirow[t]{2}{*}{ Total } & \multicolumn{3}{|c|}{ Services } & \multicolumn{2}{|c|}{ Grods } & \multirow[t]{2}{*}{ Other } & \\
\hline & & In-patient & Ous-patient & Other $1 !$ & Drugs 1 & Other & & \\
\hline & & \multicolumn{5}{|c|}{ (In millicans of Earos) } & & $(1995-100)$ \\
\hline 1970 & 21,656 & 6,670 & 6,912 & 97 & 3,502 & 468 & 4,007 & 43.8 \\
\hline 1980 & 66,417 & 22,057 & $22,15]$ & 630 & 8,872 & 3,0003 & 9,694 & 72.9 \\
\hline 1990 & 108,292 & 37,628 & 32,967 & 1,061 & 15,434 & 5,619 & 15,581 & 96.3 \\
\hline 1992 & 159,781 & 45,696 & 37,678 & 24,479 & 23,419 & 6,932 & 21,577 & 92.2 \\
\hline 1993 & 164,592 & 49,230 & 37,055 & 26,536 & 21,526 & 7,440 & 22,805 & 95.6 \\
\hline 1994 & $17,6,68 !$ & 53,619 & 39,698 & 28,659 & 22,586 & 8,186 & 23,933 & 98.0 \\
\hline 1995 & 190.388 & 57,104 & 40,187 & 34,268 & 23,884 & 8,907 & 26,035 & 100.0 \\
\hline 1996 & 199.372 & 60,117 & 41,638 & 36,188 & 25,193 & 9,853 & 26,383 & 101.0 \\
\hline 1997 & 200,208 & 62,227 & 42,446 & $34,85]$ & 25,473 & 9,303 & 25,506 & 101.7 \\
\hline $199 B$ & 204,682 & 64,543 & 41,445 & 35,641 & 26,949 & 10,463 & 25,641 & 102.8 \\
\hline 1999 & 210,426 & 65,377 & 41,737 & 36,687 & 28,408 & 11,113 & 27,054 & 103.3 \\
\hline \multirow[t]{2}{*}{2000} & 214,569 & 66,798 & 42,552 & 37,399 & 29,284 & 21,248 & 27289 & 103.1 \\
\hline & \multicolumn{8}{|c|}{ (Nominal dhange in pencent per year) } \\
\hline $1970-20003 /$ & 7.0 & 7.8 & 6.2 & 10.6 & 6.3 & 11.2 & 59 & 2.8 \\
\hline $70 \mathrm{~g}$ & 11.5 & 12.7 & 32,4 & 20.6 & 9.7 & 20.4 & 92 & 5.2 \\
\hline $80 \mathrm{~s}$ & 5.0 & 5.5 & 4.1 & 5.4 & 5.7 & 6.5 & 4.9 & 2.8 \\
\hline \multirow[t]{2}{*}{1992.2000} & 3.8 & 4.9 & 1.5 & 5.4 & 2.8 & 6.2 & 3.0 & 1.4 \\
\hline & \multicolumn{8}{|c|}{ (Real change in percent per year) $4 J$} \\
\hline $1970-20003 /$ & 3.7 & 4.4 & 2.8 & 7.1 & 2.9 & 7.7 & 2.5 & $\cdots$ \\
\hline $70 \mathrm{~s}$ & 6.3 & 7,1 & 6.8 & 146 & 4,3 & 14.4 & 3.8 & 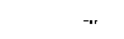 \\
\hline $\mathrm{g} x$ & 2.1 & 2.6 & 1.2 & 2.5 & 2.8 & 3.6 & 2,0 & $\cdots$ \\
\hline $1992-2000$ & 2.3 & 3.4 & 0.1 & 4.0 & 1.4 & 4.8 & 1.6 & $\ldots$ \\
\hline \multicolumn{9}{|c|}{ Sources: OECD Hesith Daka 2002 and MMF staff calculations. } \\
\hline \multicolumn{9}{|c|}{ 1/ Includes laboratory, diagnostic imagining, patient transport, emergency services, and ancillary services. } \\
\hline \multicolumn{9}{|c|}{ 2/ Dispenged to out-patients on?'y. } \\
\hline 3/ Excluding & ificaticn ye & 1990 and $] 9$ & l. & & & & & \\
\hline
\end{tabular}

CInternational Monetary Fund. Not for Redistribution 
171. The latest data indicate a renewed uptick in the growth of health care expenditure. Up-to-date information on health care expenditure is only available for outlays financed by public health insurance. Efforts to contain costs kept per capita health care expenditure growth to around 2 percent per year in the second balf of the 1990s, but it accelerated to above 3 percent in 2001 (Table V-4). Outlays for drugs have been growing at an annual rate of 6.6 percent in the last five years, thus raising a particular concern.

\begin{tabular}{|c|c|c|c|c|c|c|c|c|c|c|c|c|c|c|c|c|}
\hline \multirow[b]{3}{*}{ Total tongenditure } & \multirow{2}{*}{ 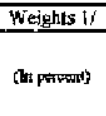 } & \multirow{2}{*}{1992} & \multirow[t]{2}{*}{1993} & \multirow[t]{2}{*}{1994} & \multirow[t]{2}{*}{1995} & \multirow[t]{2}{*}{$19 \%$} & \multirow[b]{2}{*}{ rovion $\pi$} & \multirow[b]{2}{*}{ a in pere } & \multirow[t]{2}{*}{1999} & \multirow[t]{2}{*}{2000} & \multirow[t]{2}{*}{2001} & \multirow[t]{2}{*}{$2002 y$} & \multicolumn{2}{|c|}{$1992-2002$} & \multicolumn{2}{|c|}{$1998-20-02$} \\
\hline & & & & & & & & & & & & & $\begin{array}{l}\text { (Armual } \\
\text { change in } \\
\text { per costit) }\end{array}$ & 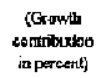 & 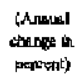 & $\begin{array}{c}\text { (Growith } \\
\text { conlrbution } \\
\text { in petcerex) }\end{array}$ \\
\hline & 500.0 & $13 . \tau$ & 0.4 & 9.9 & 5.1 & 3.1 & -2.2 & 1.9 & 21 & 2.0 & 3.7 & 3.0 & 3.7 & 3.7 & 2.5 & 2.5 \\
\hline Physicians' strotices & 15,9 & 9,8 & 3,8 & $\$ \mathbf{s}$ & 3.7 & 1.8 & 1.7 & 1,4 & 1,3 & 1.3 & 6.7 & 2.3 & 3.1 & 0.5 & 1.6 & 0.3 \\
\hline Deatints' services & 5.7 & 15.6 & 3.3 & S.t & 1.4 & 7.2 & 0.4 & 3.6 & .2 .4 & .0 .1 & 26 & 0.1 & 3.3 & 0.2 & 0.7 & 0.0 \\
\hline Denturs & 26 & 38.8 & -359 & 354 & 5.4 & 10.4 & 2.6 & -30.4 & 8.7 & 7.6 & 1.9 & -2.6 & a. 1 & 0.0 & $-3,8$ & -0.1 \\
\hline Drugg $1 /$ & [5.5 & 13 & .144 & 69 & 7.7 & 6.3 & -3.8 & 5,7 & 7,9 & 4.5 & 11.2 & 3,9 & 4,2 & 0,6 & 6.6 & 1.0 \\
\hline Hospital servicen & 32,4 & {$[1.4$} & 6.6 & 89 & 4.0 & 1.2 & 2.4 & 3.3 & -0.1 & 1.6 & 0.9 & 3.6 & 3.9 & 1.3 & 1.9 & 0.6 \\
\hline Other & 27.8 & $\ldots$ & $\ldots$ & $\ldots$ & $\ldots$ & $\ldots$ & $\ldots$ & $\ldots$ & $\ldots$ & $\ldots$ & $\ldots$ & $\ldots$ & $\ldots$ & 1.1 & $\ldots$ & 0,7 \\
\hline
\end{tabular}

172. The long-term expenditure outlook is clouded by demographic aging and cost pressures from the diffusion of increasingly sophisticated treatments. Under present policies, the pure demographic effect is estimated to add about 2 percent of GDP to publicly financed health care over the next fifty years (Chapter IV). Although hard to quantify, technological progress in medicine could deal a potentially stronger blow. In the $1990 \mathrm{~s}$ the use of expensive invasive treatment soared around the world, including in Germany where, e.g., the performance of coronary bypass surgery and coronary angioplasty more than doubled. Their use is still much less widespread than in the United States, indicating that the trend toward more invasive treatment has much room to continue. Moreover, technological cost pressures appear to be particularly pronounced in the case of the elderly, implying that rapidly aging societies would be particularly hard hit (Ulrich, 2000).

173. Health care resources and utilization are generally comparable to other OECD countries but appear exceptionally high in the hospital sector (Tables V-5 and V-6). The density of physicians, dentist, pharmacists, and technical equipment in Germany is close to that observed in other highly advanced economies. However, the number of acute-care beds in relation to population is higher than anywhere else and twice as high as in the United States. As a mirror image of this pattern, health care utilization is high by international standards in the hospital sector, but about average for patients' use of physicians and dentists. The average length of stay in acute-care is the longest among selected OECD countries and the acute-care hospital admission rate is higher only in Austria. 
Table V-5. Selected OECD Coututries: Indichtors of Health Care Resources 1/

\begin{tabular}{|c|c|c|c|c|c|c|}
\hline & $\begin{array}{l}\text { Agute caire } \\
\text { beds }\end{array}$ & $\begin{array}{l}\text { Practicing } \\
\text { physidians }\end{array}$ & $\begin{array}{l}\text { Praiticing } \\
\text { dentists }\end{array}$ & $\begin{array}{c}\text { Ptacticing } \\
\text { pharmacists }\end{array}$ & $\begin{array}{l}\text { Trtal hiospital } \\
\text { erpployment }\end{array}$ & CT scantecs \\
\hline & \multicolumn{4}{|c|}{ (Per $1,0 \mathrm{po}$ of pop.) } & \multicolumn{2}{|c|}{ (Per million of pop) } \\
\hline Austrilia & 3.8 & 2.5 & 0.3 & 0.6 & 21.4 & $\ldots$ \\
\hline Austria & 5.2 & 3.1 & 0,5 & 0.6 & 15.6 & 249 \\
\hline Be\}gium & 4.6 & 3.9 & 0.5 & 1.4 & "' & $m$ \\
\hline Canarda & 3.3 & 2.1 & 0.6 & 0.7 & 11.9 & 82 \\
\hline Denmark & 3.3 & 3.4 & 0.9 & 0.5 & 16 & 9.1 \\
\hline Finlend & 2.4 & 3.1 & 0.9 & 1.5 & .. & 12.5 \\
\hline France & 4.2 & 3.3 & $0 . J$ & 1.0 & 16.9 & 9.7 \\
\hline Germany & 6.4 & 3.6 & 0.8 & 0.6 & 113 & 17.1 \\
\hline leelond & 3.8 & 3.4 & 1.0 & 1.2 & -. & 14.8 \\
\hline Ireland' & 2.9 & 2.3 & 0.5 & 0.8 & 133 & ... \\
\hline Italy & 4,5 & 6 & 0.6 & 1.1 & 11.2 & 14.6 \\
\hline Јаряв & .- & 1.9 & 0.7 & 1.1 & 12.9 & ... \\
\hline Netherlands & 3.5 & 3,2 & 0.5 & 0.2 & 16.7 & $\cdots$ \\
\hline Xew Zealand & $\ldots$ & 2.2 & 0.4 & 0,6 & $\ldots$ & 9.0 \\
\hline Norwey & 3.1 & 2.9 & 0.8 & 0.4 & 173 & ... \\
\hline Portuggl & 3.3 & 3.2 & 0.4 & 0.8 & 10.6 & 12.3 \\
\hline Spain & 3.0 & 3.3 & 0.4 & 0.8 & 99 & 9.3 \\
\hline Swedgat & 2,4 & 2.9 & 0,9 & 0,6 & $\ldots$ & '." \\
\hline Switzerland & 4.1 & 3.5 & 0,5 & $\ldots$ & 13.8 & 18.3 \\
\hline United Kingdorr & 3.3 & 1.8 & 0.4 & 0.6 & 21.5 & $\cdots$ \\
\hline Unibed Stacts & 3.0 & $2 . B$ & 0.6 & 0.7 & 16.2 & 13.7 \\
\hline Average & 3.7 & $3:$ & 0.6 & 0.8 & 14.9 & 11.3 \\
\hline
\end{tabular}

Table V-6. Selected OECD Conntries: Indicators of Health Care Utilization $1 /$

\begin{tabular}{|c|c|c|c|c|}
\hline & $\begin{array}{c}\text { Dactors } \\
\text { Consultations }\end{array}$ & Dentist consulfations & $\begin{array}{l}\text { Acute care } \\
\text { aúrisssions }\end{array}$ & $\begin{array}{l}\text { Arerage lenglh of } \\
\text { sthy (acute sare) }\end{array}$ \\
\hline & \multicolumn{2}{|c|}{ (Fer year and person) } & (Per 1,000 of pop.) & (In days) \\
\hline Australia & 6.4 & 1.4 & 155 & 6.2 \\
\hline Austrta & 6.7 & 13 & 283 & 6.3 \\
\hline Belgium & 7.9 & 1.9 & 180 & 8.8 \\
\hline Cacada & 6.4 & $m$ & 99 & 7.3 \\
\hline Dasmark & 6.1 & 1.0 & 194 & 5.2 \\
\hline Finlabd & 4.3 & $\because$ & 203 & 4,4 \\
\hline France & 6.5 & 1.1 & 204 & 35 \\
\hline Germiany & 6.5 & 1.4 & 205 & 9.6 \\
\hline 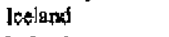 & 5.2 & $\cdots$ & 181 & 5.9 \\
\hline lretand & $\ldots$ & $\because$ & 144 & 6.4 \\
\hline taly & 6.1 & 0.9 & 176 & 7.2 \\
\hline Japan & 16.0 & 2.9 & $m$ & \\
\hline Netherlands & 5.9 & 2.4 & 93 & 9.0 \\
\hline New Zealand & $\ldots$ & $\cdots$ & $\ldots$ & 4,9 \\
\hline Norwhy & $\cdots$ & $\ldots$ & 154 & 6.0 \\
\hline Purtagal & 3.4 & $\cdots$ & 119 & 7.3 \\
\hline Spain & 7.8 & A. & 113 & 7.6 \\
\hline Sweden & 2.8 & $\ldots$ & 159 & 5.0 \\
\hline Switzerland & $m$ & $\cdots$ & 136 & 9.3 \\
\hline United Kingdom & 5,4 & 0.7 & 147 & 6.2 \\
\hline United Stater & 5.8 & .. & 118 & 5.9 \\
\hline Average & 6.5 & 1.6 & 166 & 6.6 \\
\hline
\end{tabular}

174. Despite the high level of health care spending, the health status of the German population is disappointingly mediocre. According to most commonly used indicators of population health, Germany ranks below its peers (Table V-7). In particular, the disability adjusted life expectancy (DALE) is lower than in two thirds of highly developed OECD 
countries. This low DALE score, combined with one of the highest health care spending in the world, dropped Germany's health performance to position 41 in a WHO ranking of its 191 member countries (WHO, 2000). Likewise, the OECD observed in 1997 that health outcomes in Germany disappoint given the large resources devoted to health care. Such findings do not necessarily imply inefficient health care services in the narrow sense: poor health could be driven mainly by unhealthy lifestyle choices rather than inadequate medical services, and indeed Germans fare rather poorly on lifestyle indicators. But to the extent that this is seen as a failure of health promotion, the WHO/OECD findings indicate at least that health care provision in a wider sense is inefficient.

Tabie V-7. Selected OECD Countries: Health Status Indicators

\begin{tabular}{|c|c|c|c|c|c|c|c|c|c|}
\hline & \multicolumn{2}{|c|}{ Life expectancy st birth } & \multicolumn{2}{|c|}{ Life expectansy at 2906} & \multicolumn{2}{|c|}{ DALE V } & \multirow{2}{*}{$\begin{array}{c}\text { Infant } \\
\text { mortality }\end{array}$} & \multicolumn{2}{|c|}{ PLYL 2J } \\
\hline & Fermale & Male & Femble & Male & Female & Make & & Fonale & Male \\
\hline & \multicolumn{6}{|c|}{ (In yeani) } & (Per 1,000 lis birtlas) & \multicolumn{2}{|c|}{ (Vorser per 100,00 popelation } \\
\hline Alustralia & 83.0 & 76.6 & 20.2 & 16.6 & 75.5 & 76.8 & 5.2 & 2,631 & 4,795 \\
\hline Austria & 81.2 & 75.4 & 19.4 & 15.8 & 44.4 & 68.8 & 4.8 & 2,626 & 5,014 \\
\hline Bedgiam & $B 0.8$ & 74.4 & 19.4 & 19.4 & 74.6 & 68.7 & 3.2 & $r$ & $\ldots$ \\
\hline Canada & 81.7 & 76.3 & 20.3 & 16.5 & 74.0 & 76.0 & 5.3 & 2,780 & 4,818 \\
\hline Denmart & 79.0 & 74.3 & 18.1 & 14.9 & 71.5 & 67.2 & 5.3 & 3,142 & 5,072 \\
\hline Finland & 83.0 & 73.8 & 192 & 15.1 & 73.7 & 67.2 & 3.8 & 2,560 & 5,769 \\
\hline Frande & 825 & 75.0 & 210 & 56.5 & 76.8 & 69.3 & 4.5 & 2,693 & 5,759 \\
\hline Germany & 80.7 & 74.7 & 19.2 & 15.5 & 73.5 & 67.4 & 4.4 & 2,645 & $\$, 087$ \\
\hline Iceland & 81.4 & 77.6 & 19.5 & t6.7 & 72,3 & 69.2 & 3,0 & 2,353 & 4,052 \\
\hline Irtand & 79.1 & 73.9 & $17 . \mathrm{J}$ & 14.2 & 71.7 & 67.5 & 5.9 & 2,990 & 5,563 \\
\hline Italy & 81.6 & 75.3 & 20.2 & 15.8 & 75,4 & 70.0 & $\$, 1$ & 2,464 & 4,687 \\
\hline Јарал & 84.6 & 77.6 & 21.9 & 17.0 & 77.2 & 71.9 & 3.2 & 2,133 & 4,074 \\
\hline Netherlends & 80.6 & 75.5 & 18.7 & 14,8 & 74.4 & 69.6 & 5.1 & $2,8 \mathrm{~J} 4$ & 4,297 \\
\hline New Zcoland & 80.8 & 75.7 & 19.8 & 16.4 & $\tau$ Tl. & 67.1 & 5.4 & 3,168 & 5,453 \\
\hline Narway & 81.4 & 76.0 & 19.5 & 15.7 & 74.6 & 68.8 & 3.8 & 2,567 & 4,707 \\
\hline Portugal & 79.1 & 72.0 & 17.8 & 14.3 & 72.7 & 65.9 & 5.5 & 3,312 & 7,516 \\
\hline Spain & 82.4 & 74.9 & 20.5 & 16.4 & 75.7 & 69.8 & A.6. & 2,391 & $\$ .347$ \\
\hline Sweden & 82.0 & 77.4 & 19.9 & 16.3 & 749 & 71.2 & 3.4 & 2,223 & 3,775 \\
\hline Switzerland & 82.5 & 76.8 & 20.6 & 16.8 & 75.5 & 69.5 & 4.9 & 2,581 & 4,666 \\
\hline United Kingdom & 79.8 & 75.0 & 18.5 & 15.3 & 73.7 & 69.7 & 5.6 & 2,909 & 4,766 \\
\hline Urited States & 79.4 & 73.9 & 19.1 & I6.I & 72.6 & 67.5 & 7.1 & 3,813 & 6,678 \\
\hline Average & 81.1 & +5.3 & 19.5 & 15.8 & 54.1. & 68.9 & 4.5 & 2743 & 5,100 \\
\hline
\end{tabular}

\section{Reform Efforts and Proposals}

175. Since the late 1970 s a string of health reform legislation has sought to slow the rise of health care expenditure in Germany. The thrust of reforms often shifted, with new reform measures sometimes rescinding earlier ones. The goal of stabilizing contribution rates proved illusive however.

176. The latest major reform legislation, the Health Care Reform Act 2000, seeks to stabilize contribution rates while avoiding burdening patients with higher co-payments, improve the responsiveness of the health care system to patients' needs, foster health promotion and prevention, and strengthen patients' rights. The switchover to hospital remuneration based on DRGs during 2003-07 and the planned introduction of a positive list for reimbursable drugs could stem the rise of costs. Other elements of the reform package could improve the quality of care and generate savings in the longer run. These include (i) added emphasis on health promotion and prevention; (ii) the strengthening of the position of the general practitioner through a separate budget allocation from that of specialists and 
the introduction of voluntary insurance plans where general practitioners act as "gatekeepers;" (iii) efforts to overcome the traditionally rigid separation of in-patient and outpatient care; and (iv) larger scope for technology assessment.

177. Efforts in the last two years bave focused on implementing the Health Reform Act 2000 and bringing drug expenditure growth under control. Many general provisions of the Health Reform Act 2000 needed follow-on legislation and implementing regulation. Regulation that allows insurance funds to offer disease management programs for diabetes and breast cancer are now in place. The Risk Equalization Reform Law allows extra transfers to insurance funds offering such programs. From 2003, costs for medical treatment of a patient above a certain threshold will be partially covered by a so-called high-risk pool rather than the respective insurance fund. The equalization mechanism is to be based on true morbidity criteria by 2007 . Three pieces of legislation try to cope with rising drug expenditure: target budgets were adopted, maximum reimbursable prices for drugs were lowered, pharmacists were required to substitute for prescribed high-price drugs, pharmacists' rebates to health insurances were increased, and the pharmaceutical industry agreed to make a one-off payment to public health insurers.

178. The recently re-elected government has pledged to maintain the thrust of the health reform effort (SPD, 2002). In particular, it wants to foster the use of evidenced-based medicine: a commission of independent experts would develop corresponding treatment protocols for all major diseases and determine which treatments are covered by public health insurance, a responsibility currently resting with the corporatist bodies. A similar independent commission would assess new drugs with a view of recommending insurance coverage only for those with significant value added. Contractual relations between insurers and providers would be further liberalized, but the traditional collective agreement with regional doctors' associations would remain the norm. Distribution of drugs by mail would be allowed. Last but not least, the income threshold for opting out of public health insurance would be increased. The main opposition party likewise favors an evolutionary approach. It advocates, however, rolling back government regulation, such as budgets and restrictions on the number of doctors, and fostering more variety in health plans regarding out-of-pocket payments and coverage (CDU/CSU, 2002 and Stewens et al., 2001).

179. Other groups propose more radical reform. A group of experts close to the government would abolish collective contracts with doctors' associations altogether and broaden the tax base of social security (Friedrich-Ebert-Stiftung, 2002). The Kronberger Kreis (2002), a pro-market think tank, would replace public health insurance with the requirement to purchase a basic benefit package from competing private insurers that would charge risk-based premiums and contract with providers of their choice. In 2000, the Council of Economic Advisers had advanced a similar idea (Sachverständigenrat, 2000).

\section{Possible Reform Priorities}

180. Reform steps should address some fundamental distortions of the system: the lack of patients' incentives to take costs into account, providers' bias to provide excessive treatment, and the disincentive for developing cost-saving new technology. There is a broad 
consensus that co-payments are an indispensable tool for sharpening patients' cost awareness. And, if applied selectively, they can also help mitigate providers' bias toward excessive treatment. But they are no panacea and there is much less consensus of how to deal with the remaining bias toward excessive health care. Two regulatory options are explored in more detail: global budgets and government support for cost-saving innovation.

\section{Patient co-payments}

\section{At the very least, co-payments would provide for less distortionary health care} financing than sole reliance on payroll taxes. Total social security contributions now top 41 percent of gross wages and inhibit the functioning of the labor market. This concern would be lessened if some health care financing could be shifted off social security contributions onto patient co-payments. The shift could be arranged so that income is not redistributed between employers and employees.

182. Co-payments would provide for better patient and physician incentives to choose less treatment and more cost-effective treatment. It is sometimes argued that existing copayments in Germany have done little to reduce health care demand. But this likely reflects their modesty and structure, rather than a general ineffectiveness. It is hard to imagine that a co-payment of 69 per day for in-patient care would seriously deter anyone from excessively long hospital stays. Similarly, co-payments on drugs that depend on pack size but not on the price of the drug hardly induce patients to opt for low-price alternatives. The broader experience, however, does suggest that co-payments work. In surveying the empirical literature, Zweifel and Manning (2000, p.436) conclude that "a number of observational studies have found that the demand for health care falls with increases in out-of-pocket costs, across a variety of populations and institutional settings. The magnitude of the estimated response varies widely, however." From a theoretical point of view the merits of copayments are even more clear cut: full insurance eliminates all financial incentives for patients to opt for cost-effective treatment while providers typically face financial incentives conducive to excessive treatment. Co-payments eliminate this one-sided bias. The basic truth of Arrow's 1963 finding remains valid: the optimal health insurance contract involves out-ofpocket payments in the form of co-insurance and a deductible.

183. Co-payments could be differentiated to elicit more efficient consumer behavior. Once co-payments are generally in place, selective reductions can be used to influence consumer choice for the better. Rebates could be offered to those who choose a healthy lifestyle, e.g., by refraining from smoking, getting sufficient exercise, following a healthy diet, etc., and those who adhere to a preventive check-up program.

\section{Selective co-payment rebates could serve as a substitute for selective insurance-} provider contracting. It has rightly been argued that competition between insurance funds is rather pointless as long as they all contract with the same providers at identical terms. Room for efficiency gains at the level of insurance funds is probably rather limited, although competition might help to bring down their administrative costs and spur more health promotion. With the bulk of the potential efficiency gains at the level of health care providers, it is essential that competition among insurances is mainly about selecting cost- 
effective providers. Outright selective contacting, however, gives rise to a number of problems: (i) it challenges the traditionally strong position of doctors' associations, which are currently the contractual partners of insurance funds; (ii) it is hard to square with free access, as insurance funds would have agreements only with a subset of providers; and (iii) it would take a substantial effort to establish the host of new contracts that would be required, given the large number of insurance funds and providers. Co-payments with rebates for the use of cost-effective providers would offer much the same advantages as selective contracting while avoiding such problems. Competition among insurance funds would be about identifying cost-efficient providers and then offering reduced co-payments to induce their members to use them. Doctors' associations could continue to play their traditional role and access would remain free.

\section{Increasing co-payments raises the specter of undermining social solidarity.} Germany's health care system involves redistribution in its use and its financing. It redistributes income from the healthy to the sick because treatment is essentially free of charge. It also redistributes income from the rich to the poor because it is financed through a proportional payroll tax: the more you earn the more you pay. How all this affects equity depends on which concept of equity is considered, a much discussed topic in the health care literature (Hurley, 2000). Using equality of income as the yardstick, the free use of health care has no systematic effect on equity. Financing likely improves equity, but probably less so than one might think: the rich can opt out of public health insurance, the tax does not apply to capital income, and labor income above a certain threshold goes untaxed (Breuer and Zweifel, 2002). A system of co-payments probably does not worsen equity, as long as the ceiling for co-insurance and the deductible are linked to income. Consider, for example, a scheme with a 20 percent co-insurance up to 10 percent of income and a deductible of 1 percent of income. In years where the ceiling for co-insurance is reached it has better equity properties than the current system since all income is considered in determining the co-insurance ceiling. In no-claim years, the equity properties are worse, and in all other years the effect is ambiguous.

\section{Regulatory options}

186. For all the efforts to strengthen incentives, a bias toward excessive health care spending remains. Even with substantial co-payments, patients do not face the full marginal cost of treatment. Health care demand remains excessive. Even with competition among insurers and providers, elements of cost recovery in provider remuneration would be hard to eliminate fully. Incentives for overtreatment are stifl present. And co-payments do not even begin to address the dynamic dimension of the bias.

\section{A global budget could serve as a second line of defense but would give rise to} other problems. Budgets are a double-edged sword. Most economists are critical as a global budget might fix an inefficient level or composition of health care expenditure (see, e.g., Zweifel and Breyer, 1997). Yet, in practice, systems with open budgets have not fared well. Hsiao (2000) suggests that it is more than mere coineidence that the two countries with the most open budgets, the United States and Switzerland, also feature the highest health care spending ratios. 
188. Existing budgeting could be improved upon. Efficiency losses can be particularly pronounced if budgets pin down spending in narrow categories. For example, separate budgets for drugs and other medical services might inhibit the use of cost-effective drug therapy in lieu of surgery. Elements of historic-cost budgeting in the case of hospitals perversely punishes past efforts to increase efficiency. A truly global budget covering all health care expenditure under the public health insurance would avoid such problems. But it would be essential to devise an implementation mechanism that steers the overall squeeze on resources to areas of inefficiencies. Utilization reviews would be a possibility. Such reviews could conclude, for instance, that Germany's system of dual hospital financing hinders reduction of excess bed capacity or that overly generous margins for pharmacies lead to excessive market entry.

\section{Governments are attempting to redress the dynamic bjas toward excessive} health care through technology-assessment mechanisms and, in the case of pharmaceuticals, through positive lists. Essentially, if the entity charged with technology assessment determines a new technology, or drug, to be cost-ineffective it is excluded from insurance coverage. The hope is that it will thus not be developed in the first place or at least not readily applied to large numbers of patients. Medical innovation in the global marketplace is, however, outside the control of any government. New medical treatments and drugs are developed for world markets rendering futile unilateral national efforts to alter the incentive structure.

190. Biased incentives in medical innovation could be balanced by governmentsponsored research and development. If incentives to develop marginal and cost-pushing technologies cannot be lessened by any national government, it could at least compensate by directly sponsoring cost-saving medical innovation. With significant research and development resources already under government control a redeployment of existing funds might be all what is needed. 


\section{References}

Arrow, Kenneth J. (1963), "Uncertainty and the Welfare Economics of Medical Care," American Economic Review, 53.

Breuer, Michael and Peter Zweifel (2002), "Mehr Markt im Gesundheitswesen tut Not," in: ifo-Schnelldienst, 55(17), ifo Institut für Wirtschaftsforschung, München.

Bundesanstalt für Arbeit (2002), "Arbeitsmarkt-Information für qualifizierte Fach- und Führungskräfte: Ärztinnen und Ärzte," Arbeitsmarktinformationsstelle, Bonn.

Bundesministerium für Gesundheit (2001), "Daten des Gesundheitswesens, Ausgabe 2001," Nomos Verlagsgesellschaft Baden-Baden.

Busse, Reinhard (2000), "Gesundheitssysteme im Wandel - Deutschland," Europäisches Oberservatorium für Gesundheitssysteme 2000, AMS 5012667(DEU).

Busse, Reinhard (2002), "Germany," in: Europäisches Oberservatorium für Gesundheitssysteme, "Health Care Systems in Eight Countries: Trends and Challenges," edited by A. Dixan and E. Mossialos, London.

CDU/CSU (2002), "Leistung und Sicherheit - Zeit für Taten, Regierungsprogramm 2002/06," Christlich Demokratische Union Deutschlands and Christlich-Soziale Union, Beschluss des Parteitags.

Cutler, David M. (1996), "Why Don't Markets Insure Long-term Risk," mimeo, Department of Economics, Harvard University, Boston.

(2002), "Equality, Efficiency, and Market Fundamentals: The Dynamics of International Medical-Care Reform," Journal of Econtomic Literature, XL(3).

Friedrich-Ebert-Stiftung (2002), "Eckpunkte einer neuen Gesundheitspolitik," Berlin.

Holahan, Jobn (1997), “Crowding Out; How Big a Problem?," Health Affairs, 16(1).

Hurley, Jeremiah (2000), "An Overview of the Normative Economics of the Health Sector," in: Handbook of Health Economics, Volume I, edited by A. J. Culyer and J. P. Newhouse.

Hsiao, William (2000), "What Should Macroeconomist Know About Health Care Policy? A Primer," IMF Working Paper, WP/00/136.

Jost, Timothy S. (2001), "Private or Public Approaches to Insuring the Uninsured: Lessons from International Experience with Private Insurance," New York University Law Review, 79:419. 
Kronberger Kreis (2002), "Mehr Eigenverantwortung und Wettbewerb im Gesundheitswesen," Stiftung Marktwirtschaft, Frankfurter Institut, Frankfurt.

Luft, Harold S. (1986), "Compensating for Biased Selection in Health Insurance," Milbank Quarterly, 64(4).

Nickel, Stephan and Richard Layard (1999), "Labor Market Institutions and Economic Performance," in: Handbook of Labor Economics, edited by O. Ashenfelder and D. Card, Chapter 46.

OECD (1997), "OECD Economic Surveys: Germany," Organization for Economic Cooperation and Development, Paris.

(2002), "OECD Health Data 2002; A Comparative Analysis of 30 Countries," Organization for Economic Cooperation and Development, Paris.

Public Health Insurance Fund (2002), "Fragen zur Gesundheitspolitik," http://g-kv.com/faqgesundsystem.html.

Rothschild, M. and Joseph E. Stiglitz (1976), "Equilibrium in Competitive Insurance Markets: an Essay on the Economics of Imperfect Information," Quarterly Journal of Economics, 90 .

Sachverständigenrat zur Begutachtung der gesamtwirtschaftlichen Entwicklung (2000), "Chancen auf einen höheren Wachstumspfad," Jahresgutachten 2000/01, MetzlerPoeschel, Stuttgart.

SPD (2002), "Erneuerung und Zusammenhalt - Wir in Deutschland, Regienungsprogramm 2002-2006," Sozialdemokratische Partei Deutschlands, Beschluss des Parteitags.

Statistisches Bundesamt (2000), "Gesundheitsberichterstattung 1998," Wiesbaden. (2002), "Gesundheit - Personal 2000," Wiesbaden. (2002), "Gesundheit - Ausgaben 1992 bis 2000," Wiesbaden.

Stewens, Christa, Horst Seehofer, and Wolfgang Zöller (2001), "Gesundheitspolitik für das neue Jahrhundert, Mehr Gesundheit - mehr Qualität - mehr Verantwortung," Christlich-Soziale Union.

Ulrich, Voiker (2000), "Medizinisch-technischer Fortschritt, demographische Alterung und Wachstum der Gesundheitsausgaben: Was sind die treibenden Faktoren?," Gesundheitsökonomie \& Gesundheitsmanagement, 5, 2000.

WHO (2000), "The World Health Report 2000 - Health Systems: Improving Performance" World Health Organization, Geneva. 
Zweifel, Peter and Friedrich Breyer (1997), "Health Economics," Oxford University Press. and Willard G. Mamming (2000), "Moral Hazard and Consumer Incentives in Health Care," in: Handbook of Health Economics, Volume I, edited by A. J. Culyer and J. P. Newhouse.

CInternational Monetary Fund. Not for Redistribution 